\title{
Constraints on the Late Saalian to early Middle Weichselian ice sheet of Eurasia from field data and rebound modelling
}

\author{
KURT LAMBECK, ANTHONY PURCELL, SVEND FUNDER, KURT H. KJÆR, EILIV LARSEN AND PER MÖLLER
}

\section{BOREAS}

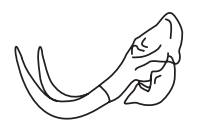

Lambeck, K., Purcell, A., Funder, S., Kjær, K.H., Larsen, E. \& Möller, P. 2006 (August): Constraints on the Late Saalian to early Middle Weichselian ice sheet of Eurasia from field data and rebound modelling. Boreas, Vol. 35, pp. 539-575. Oslo. ISSN 0300-9483.

Using glacial rebound models we have inverted observations of crustal rebound and shoreline locations to estimate the ice thickness for the major glaciations over northern Eurasia and to predict the palaeo-topography from late MIS-6 (the Late Saalian at c. $140 \mathrm{kyr}$ BP) to MIS-4e (early Middle Weichselian at c. $64 \mathrm{kyr}$ BP). During the Late Saalian, the ice extended across northern Europe and Russia with a broad dome centred from the Kara Sea to Karelia that reached a maximum thickness of $c .4500 \mathrm{~m}$ and ice surface elevation of $c .3500 \mathrm{~m}$ above sea level. A secondary dome occurred over Finland with ice thickness and surface elevation of $4000 \mathrm{~m}$ and $3000 \mathrm{~m}$, respectively. When ice retreat commenced, and before the onset of the warm phase of the early Eemian, extensive marine flooding occurred from the Atlantic to the Urals and, once the ice retreated from the Urals, to the Taymyr Peninsula. The Baltic-White Sea connection is predicted to have closed at about $129 \mathrm{kyr}$ BP, although large areas of arctic Russia remained submerged until the end of the Eemian. During the stadials (MIS-5d, 5b, 4) the maximum ice was centred over the Kara-Barents Seas with a thickness not exceeding c. $1200 \mathrm{~m}$. Ice-dammed lakes and the elevations of sills are predicted for the major glacial phases and used to test the ice models. Large lakes are predicted for west Siberia at the end of the Saalian and during MIS-5d, 5b and 4, with the lake levels, margin locations and outlets depending inter alia on ice thickness and isostatic adjustment. During the Saalian and MIS-5d, 5b these lakes overflowed through the Turgay pass into the Aral Sea, but during MIS-4 the overflow is predicted to have occurred north of the Urals. West of the Urals the palaeo-lake predictions are strongly controlled by whether the Kara Ice Sheet dammed the White Sea. If it did, then the lake levels are controlled by the topography of the Dvina basin with overflow directed into the Kama-Volga river system. Comparisons of predicted with observed MIS-5b lake levels of Komi Lake favour models in which the White Sea was in contact with the Barents Sea.

Kurt Lambeck (e-mail: Kurt.Lambeck@anu.edu.au) and Anthony Purcell, Research School of Earth Sciences, The Australian National University, Canberra 0200, Australia; Svend Funder and Kurt H. Kjar, Natural History Museum of Denmark, Geological Museum, University of Copenhagen, Øster Voldgade 5-7, DK-1350 Copenhagen, Denmark; Eiliv Larsen, Geological Survey of Norway, NO-7002 Trondheim, Norway; Per Möller, GeoBiosphere Science Centre, Quaternary Sciences, Lund University, Sölvegaten 12, SE-223 62 Lund, Sweden; received 28th September 2005, accepted 27th March 2006.
The evolution of the ice sheet over northern Europe since the time of the last maximum glaciation is well understood as a result of geomorphological observation (e.g. Boulton et al. 2001) and glaciological modelling (e.g. Lambeck et al. 1998b). Estimates of the thickness of the former ice remain rare, however, and the inversion of rebound and sea-level data has proved to be a useful additional component for placing constraints on ice thicknesses, particularly during the retreat phase. Ice-sheet evolution during the earlier period of the last cycle is less well understood, in part because the older record has frequently been overprinted by later advances and retreats and in part because the accuracy and reliability of the chronological control decreases once the time scale exceeds the limits of radiocarbon dating. For the same reasons the observations required for a successful inversion of rebound data for ice thickness are also fewer and less reliable. An understanding of the ice-sheet fluctuations during this earlier period is nevertheless important for understanding the inception of ice sheets after a prolonged interstadial, for quantifying the rates of ice-sheet growth and decay, and for constraining models of climate during a full glacial cycle.

The extensive field programmes in the Eurasian north over the past decade have led to major new insights into the ice-sheet evolution over the Russian sector (Larsen et al. 1999a; Thiede \& Bauch 1999; Thiede et al. 2001, 2004; Thiede 2004; Kjær et al. 2006a) and when combined with the Scandinavian evidence (Houmark-Nielsen 2004; Lundqvist 2004; Mangerud 2004; Ehlers \& Gibbard 2004) it is possible to construct tentative ice models for some important past epochs, particularly for the Late Saalian, the stadials of marine isotope stage 5 (MIS-5d and 5b) and MIS-4, in addition to the Last Glacial Maximum (LGM). The pre-LGM shoreline and sea-level observations are too few and incomplete to contemplate their formal inversion for ice model parameters, but they may provide the means for testing competing hypotheses about aspects of the former ice sheets or for identifying incompatible aspects of these hypotheses. 
This is what we explore in this article. We do this through the development of an isostatic rebound model across the region that predicts the timing and location of shoreline formation. We then compare the observational shoreline evidence with the model predictions to determine whether aspects of the ice model need modification or whether there are essential and robust features that any ice model for this region and epoch must possess. In space, the focus is on the northern Eurasian ice sheet extending from the North Sea in the west to the Taymyr Peninsula in the east, including the Barents-Kara Sea and the arctic islands from Svalbard to Severnaya Zemlya. In time, the focus is on the period from the Late Saalian (c. $140 \mathrm{kyr} \mathrm{BP}$ ), when the ice sheets were larger than at any time during at least the last two glacial cycles, to the final retreat of the MIS-4 glacier ice from the arctic Russian plain at c. $60 \mathrm{kyr}$ BP.

We first present a summary of the field evidence for the major glaciation phases that captures the principal features of the advances and retreats across northern Europe and western arctic Russia. This forms the basis for developing quantitative models for predicting crustal rebound, sea level and shoreline locations during the glacial cycle. Observationally constrained ice margins are used for the entire period from MIS-3 to the Holocene, but this will be discussed elsewhere. The chronology for the Eurasian ice-volume changes adopted here is based on the U/Th constrained global sea-level curve on the assumption that the latter integrates a near-synchronous response of all ice sheets to global changes in climate. The observational evidence for palaeo-sea levels and shoreline locations is primarily constrained with OSL age data that we assume correspond to the U/Th time scale. For the Eemian interval the relative pollen chronology of northern Europe established by Zagwijn (1996) is used and this is related to the absolute chronology in an iterative way using the preliminary ice model to establish differential isostatic signals between his northern European pollen localities and the sites far from former ice margins upon which the global sealevel curve is based.

Because of the Earth's viscosity, sea level at any epoch is a function of the ice history both before and after that epoch: the observation is one of the position of a palaeo-shoreline relative to the modern shoreline and the latter is a function in particular of the last deglaciation (Potter \& Lambeck 2003). Thus the model for the ice history has to include both a period before the Late Saalian and the time after MIS-4, although the details of the post-MIS-4 ice model will be discussed separately. Provided that the model predictions and inferences are limited to the interval after about $140 \mathrm{kyr}$ BP, then the assumptions about the preSaalian interval are not critical and we extend the model back to the penultimate interglacial MIS-7. The preliminary model used to estimate ice thickness as a function of time for the two glacial cycles is based on simple glaciological concepts in which ice thickness is quantified in terms of one or more scaling parameters estimated from the comparison of the model predictions of sea level with the observational evidence.

The crust and sea level response to the totality of the changes in global ice sheets and any observation of shoreline elevation contains a signal from fluctuations in the North American and Antarctic ice sheets. Thus assumptions about the global changes in ice volume will need to be made, but in view of the rather large uncertainties of the pre-LGM observations these assumptions are not critical at present. To describe the rebound model and the earth-response function, we consider the planet to be a linear system over the period of the glacial cycles, an assumption that is dictated by a lack of evidence for quantifying any nonlinear response model but which is also supported by the consistency of mantle viscosity estimates from mantle inversion studies on longer time scales with those obtained from the glacial rebound analyses (Cadek \& Fleitout 2003). Thus, we assume that the optimum model parameters inferred from the analysis of post-LGM rebound are also valid for the longer period. Any uncertainty introduced by this assumption or by the choice of actual parameters will be small when compared with uncertainties in the ice model.

The observational sea-level constraints from the Eurasian north used to test the model predictions include Eemian shoreline elevations, the timing and extent of the Baltic opening to the White Sea, and Early to Middle Weichselian shoreline elevations from the North Sea to the Taymyr Peninsula. Eemian and Weichselian evidence from Svalbard is also used in the analysis, but this will be discussed in more detail elsewhere. The preliminary ice model, together with the rebound model and earth-response function, determines the first iteration predictions for palaeoshoreline locations and elevations. If systematic discrepancies occur between these predictions and the observational evidence, then these will be used to refine the ice model iteratively until agreement is reached within the combined uncertainties of the field data and model predictions. We emphasize that much of the starting ice model rests on questionable assumptions and that it may be little more than guesswork for the earliest period, but if the ice margin information is reliable and the shoreline data are spatially and temporally representative then the final ice model for the Late Saalian to Middle Weichselian will be independent on the initial assumptions made. The criteria of representativeness are not satisfied with the present data set and the results will undoubtedly be subject to revision as new field data become available, but the model should have some predictive capabilities about, for example, the ice thickness at glacial maxima, whether the ice sheet is single- or multi-domed, the location and timing of ice-dammed lakes along the 
southern margins of the Eurasian ice sheets, the timing and duration of the Eemian sea connection between the Baltic and the White Sea, or about the timing and extent of marine transgressions across the lowlands of arctic Russia.

\section{Ice-margin chronology and location}

\section{Saalian and pre-Saalian}

The Late Saalian corresponds to a prolonged cold period for Europe during which the ice extended further south than for any subsequent period (e.g. Svendsen et al. 2004) and the advance occurred in at least two phases: the Drenthe and the Warthe. We know of no observational constraints that indicate the nature of the initiation of the Saalian ice sheet and, in order to construct a starting model for the ice growth, we have assumed that it followed a similar pattern to that inferred for the Weichselian: that is, ice growth initiated over the Kara Sea and expanded over the Russian arctic, while early ice growth over Scandinavia was restricted to the highlands. The early chronology is established from the oxygen isotope curve for the penultimate glacial cycle of Waelbroeck et al. (2002) and from the coral evidence for the time global sea levels first reached present-day levels (Stirling et al. 1998). Furthermore, we assume that the Eurasian ice volumes are in phase with global changes. Because sea-level predictions for only the Late Saalian and subsequent periods are considered, such simplifying assumptions for the pre-Late Saalian period do not affect the general conclusions drawn about the later ice sheets.
The chronology adopted for the MIS-6 ice over Eurasia is as follows (see Fig. 1 for locations of principal sites mentioned in text):

- Interglacial conditions existed at c. $210 \mathrm{kyr}$ BP, with global ice volumes similar to those of today.

- Ice growth commenced primarily in the Kara Sea area, similar to the development during the early part of the last cycle.

- An oscillatory increase in ice volume occurs from c. $195 \mathrm{kyr}$ BP up to the Drenthe advance with ice volumes growing in the same ratio as the icevolume equivalent-sea-level change. By $180 \mathrm{kyr}$ BP the ice sheet has expanded over the Barents-Kara Sea, the Taymyr and Putorana areas of arctic Russia, and over Norway, northern Sweden and Finland. The ice margins at this time are assumed to have been similar to those that occurred later during the stadials MIS-5d and $5 \mathrm{~b}$.

- The Drenthe maximum occurs at c. $155 \mathrm{kyr}$ BP and has a duration of $c .5 \mathrm{kyr}$.

- Some ice retreat occurs between the Drenthe and Warthe, consistent with the sea-level rise inferred at c. $150 \mathrm{kyr}$ BP. This is followed by a readvance to the Warthe maximum at $c .143 \mathrm{kyr}$ BP.

- The Warthe maximum lasts until $140 \mathrm{kyr} \mathrm{BP}$ and is followed by rapid melting. The penultimate glacial maximum over Scandinavia ends at c. $135 \mathrm{kyr}$ BP, corresponding to the midpoint between the onset of the Warthe deglaciation and the time sea levels globally reached their present level in the subsequent interglacial. By $135 \mathrm{kyr}$ BP the Russian ice has retreated to the Kara Sea.
Fig. 1. Location map for principal sites and localities in northern Europe and Russia discussed in text. $1=$ Laptev Sea; $2=$ Chelyuskin; $3=$ October Revolution Island; $4=$ Lake Taymyr; $5=$ Khatanga River; $6=$ Byrranga Mountains; $7=$ Agapa River; $8=$ Gydan Peninsula; $9=$ Yamal Peninsula; $10=$ Taz Peninsula; $11=\mathrm{Ob}$ River; $12=$ Sob pass; $13=$ Turgay pass; $14=$ Pechora Lowlands; $15=$ Keltma pass; $16=$ Mylva pass; $17=$ Sula River; $18=$ Timan Ridge and Tsilma Pass; $19=$ Pyoza River; $20=$ Kanin Peninsula; $21=$ Mezen Lowlands; $22=$

Arkhangelsk Lowlands; $23=$ Vaga River; 24 =White Sea; 25 =Lake Onega; $25 \mathrm{a}=$ Karelia watershed; 26 =Neva Lowlands; 27 =Finnmark; $28=$ Finland Gulf; $29=$ Prangli; $30=$ Riga Bay; $31=$ Ostrobothnia; $32=$ Gulf of Bothnia; $33=$ Northern Sweden (Boliden); $34=$ Central Sweden (Dellen, Bollnäs); $35=$ Vistula; $36=$ Skåne (Stenberget); $37=$ Danish Bælts; $38=$ Schleshwig-Holstein; $39=$ Jylland; $40=$ Fjøsanger; $41=$ Wadden Sea and North Friesian Islands.

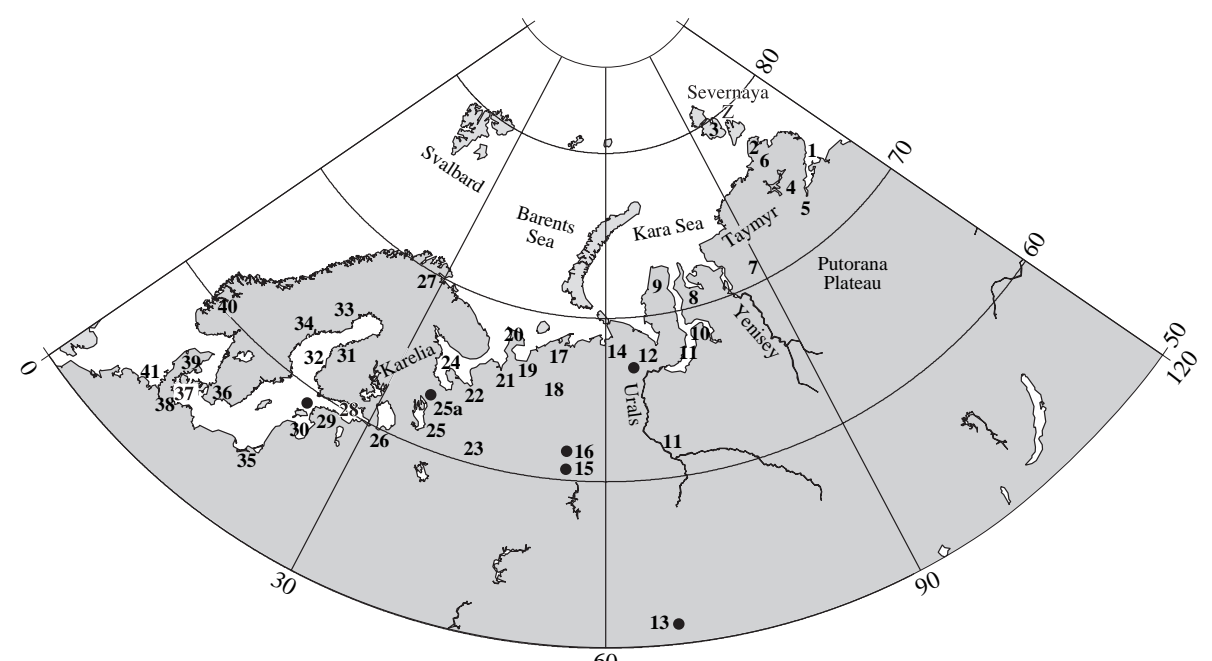



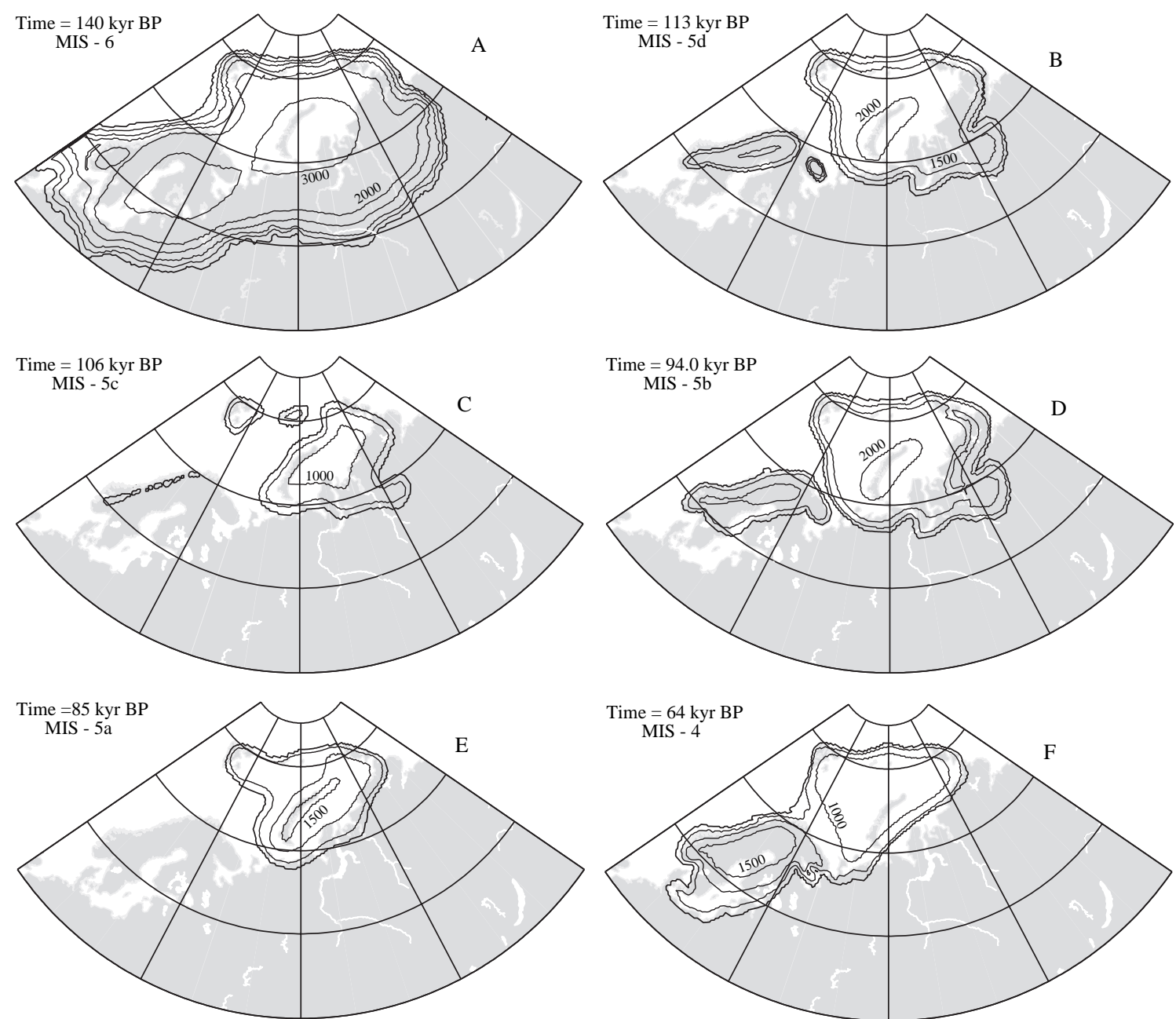

Fig. 2. Ice-margin locations and ice-thickness estimates for the preliminary ice model at selected epochs corresponding to the major stadials and interstadials. A. The Warthe phase of the Late Saalian or late MIS-6 at $c .140 \mathrm{kyr}$ BP. B, D. The Early Weichselian cold phases MIS-5d at c. $113 \mathrm{kyr}$ BP and MIS-5b at c. $94 \mathrm{kyr}$ BP. C, E. The Early Weichselian interstadials MIS-5c at $c .106 \mathrm{kyr}$ BP and MIS-5a at $c$. $85 \mathrm{kyr}$ BP. F. The Early Middle Weichselian stadial MIS-4 at c. 65 kyr BP. The contour intervals are 0, 500, 1000, 1500, 2000 and $3000 \mathrm{~m}$.

Two recent compilations have been used to establish the ice margins for the Warthe phase of the Late Saalian (Ehlers \& Gibbard 2003, 2004; Svendsen et al. 2004) (Fig. 2A). At this time, the Barents Sea was glaciated with an ice sheet extending out to the shelf edge west of Svalbard and Bear Island (Mangerud et al. 1998) and into the Arctic Ocean (Spielhagen et al. 2004). The southern margin in Siberia lies some $1400 \mathrm{~km}$ south of the arctic coastline. In the west, the ice sheet extends across the North Sea and joins up with the British ice sheet, the ice margin of which is assumed to have been similar to that for the Late Devensian - corresponding to the Late Weichselian. In so far as the model predictions will not be used for sites in the British Isles and because the volume of ice over the British Isles represents only a few percent of the volume of the MIS-6 Eurasian ice, this approximation is adequate.
Predictions of post-Saalian sea level are a function of the duration of the preceding glaciation and the reason for introducing the Drenthe phase is to ensure that the ice sheet remained near its maximum limits for the duration of the global lowstands in sea level. The Drenthe advance limits are taken to be the same as for the Warthe phase, based on the observation that the marine oxygen isotope values are similar for the two periods. The extent of the retreat between the two advances across the European and Siberian plains appears to be unconstrained and it has been moved back by an amount that ensures the percentage reduction of ice volume is consistent with that inferred from the global sea-level curve. The principal consequence of the Drenthe advance is that the duration of maximum glaciation (c. $20 \mathrm{kyr}$ ) is sufficiently long for the mantle to have reached a significant fraction of the equilibrium stress state at the time of the Warthe deglaciation onset, such that the earlier load oscilla- 
Table 1. The relative chronology and duration of pollen zones for the North Sea, Baltic and the Baltic-Arctic seaway of Müller (1974) and Zagwijn (1996), the preliminary 'absolute' chronology of Funder et al. (2002) and the final adopted chronology in which the relative sea-level data of Zagwijn have been corrected for isostatic and tectonic effects. The shaded zones mark the early Eemian.

\begin{tabular}{|c|c|c|c|c|c|c|}
\hline \multirow[t]{2}{*}{ Pollen zone } & \multirow[t]{2}{*}{ Species } & \multirow[t]{2}{*}{ Duration (kyr) } & \multicolumn{2}{|c|}{ Initial chronology } & \multicolumn{2}{|c|}{ Modified chronology } \\
\hline & & & Start (kyr BP) & End (kyr BP) & Start & End \\
\hline E6b & Pinus & 2.5 & 122.0 & 119.5 & 122.0 & 119.5 \\
\hline E6a & Picea & 2 & 124.5 & 122.0 & 124.0 & 122.0 \\
\hline E5 & Carpinus & 3.5 & 129.5 & 124.5 & 128.0 & 124.5 \\
\hline $\mathrm{E} 4 \mathrm{~b}$ & Taxus/Tilia & 1.1 & 130.6 & 129.5 & 129.1 & 128.0 \\
\hline E4a & Corylus & 0.7 & 131.3 & 130.6 & 129.8 & 129.1 \\
\hline E3b & Quercus, Corylus & 0.45 & 131.75 & 131.3 & 130.25 & 129.8 \\
\hline E3a & Quercus & 0.25 & 132.0 & 131.75 & 130.50 & 130.25 \\
\hline $\mathrm{E} 2 \mathrm{~b}$ & Pinus, Quercus & 0.2 & 132.2 & 132.0 & 30.70 & 130.5 \\
\hline E2a & Pinus, Ulmus & 0.2 & 132.4 & 132.2 & 130.90 & 130.7 \\
\hline E1 & Betula, Pinus & 0.1 & 132.5 & 132.4 & 131.0 & 130.9 \\
\hline
\end{tabular}

tions are of little consequence on post-Late Saalian predictions. The large oscillation sometimes reported in sea level immediately prior to the start of the Last Interglacial (MIS-5e) (Esat et al. 1999) has not been attributed here to fluctuations in the Late Saalian ice sheet.

\section{Eemian (MIS-5e)}

In the deep sea record the onset of the Last Interglacial and MIS-5e is usually defined as the time when global sea level was midway between its lowest value at the end of the glacial maximum at $c$. $140 \mathrm{kyr}$ BP and the time at which present sea level was first reached at c. 130-129 kyr BP (Stirling et al. 1998), or at c. $135 \mathrm{kyr}$ BP. This is not a precise definition, because the time at which the sea-level rise started is not well constrained and the rise may not have been uniform as is indicated by the oscillation that may have occurred during this rise (Esat et al. 1999). In northern Europe the definition of the Eemian period is based on the fossil pollen record, and the relative chronology defined by Müller (1974) and Zagwijn (1996) is adopted here (Table 1). The Eemian is characterized by a uniform vegetation development and similar pollen zones can be identified across the entire region from the Atlantic coast and North Sea to the Arkhangelsk region. In particular, for the early Eemian (the pollen zones E1-E4 of Zagwijn 1983, 1996), differences in arrival time of species across the region appear to have been small and the relative chronology is assumed to be the same across the region (Zagwijn 1996; Grichuk 1984; Eriksson 1993). Beginning with the Carpinus zone (zone E5) differences in the timing of the pollen zones across the region may have been greater, but because most of the evidence discussed here relates to the early period this is not significant for present purposes. Thus we adopt this relative chronology across northern Europe.

In the pollen diagrams, the interval E2a to E4b is a time when temperatures were higher than at any time during the remainder of the interglacial or at any time during the Holocene. This interval is also characterized by Baltic Sea salinities that were higher than at any other time in either the Eemian or Holocene (Funder et al. 2002). Evidence from The Netherlands (Zagwijn 1983, 1996; Beets \& Beets 2003) and northwestern Germany (Caspers et al. 2002) indicates that the warmest conditions occurred shortly before the cessation of the rapid sea-level rise in this region and the usual practice has been to relate the end of E4b to the time of cessation of the global sea-level rise (Funder et al. 2002; Beets \& Beets 2003). However, this association needs examination because of differential isostatic contributions among the North Sea and western Baltic locations and with respect to the sites used to establish the global sea-level function. Without knowledge of the Late Saalian ice sheet this lag cannot be evaluated, and in the first instance we adopt the same assumption and return to the relationship between the pollen and U/Th time scale once a satisfactory approximation of the ice model has been derived. Zagwijn (1996) defines the start of the Eemian as the pollen zone E1, c. 3000 years before the end of zone $4 \mathrm{~b}$ (Table 1), and this places it at 132-133 kyr BP in the preliminary U/Th time scale (Funder et al. 2002). This is later than in the previous definition of c. $135 \mathrm{kyr}$ BP for the start of MIS-5e, but for the present we adopt the time of onset of the pollen zone E1 at $132.5 \mathrm{kyr} \mathrm{BP}$, implying that this occurred c. $2.5 \mathrm{kyr}$ after the onset of the interglacial as defined by the mid-point between the end of the glacial maximum and the time at which present sea level was first reached. For European Russia and West Siberia we adopt the stratigraphic nomenclature and equivalences summarized by Larsen et al. (1999a) and we assume that the boreal period as far east as the Taymyr Peninsula has the same chronology as its northern European counterpart.

The end of MIS-5e is defined as the time of onset of the global sea-level fall (c. 119-120 kyr BP) and the 
observed duration of interglacial sea levels near their present value (c. 10-11 kyr) compares well with the estimated duration of the pollen zones E5-E6b of Müller (1974) and with his inference that the interglacial ended with the end of the E6-b pollen zone. Thus, we fix the end of the pollen zone E6b at $119.5 \mathrm{kyr}$ BP.

\section{Early Weichselian}

The Weichselian of Europe covers the interval from the end of MIS-5e (c. $119 \mathrm{kyr}$ BP) to the start of the Holocene at c. $11.5 \mathrm{kyr}$ BP and corresponds to the isotope stages $5 \mathrm{~d}$ to 2 . Much of the Weichselian chronology is relative only, determined by stratigraphic relationships of successive glacial and interglacial deposits. Radiocarbon ages for the younger interval and Thermo-Luminescence (TL), Optically Stimulated Luminescence (OSL) and Electron Spin Resonance (ESR) dates for the earlier period are used where available although reliable results remain few. We assume here, therefore, that the Russian-European succession of major glacials and interglacials follows the oscillations of the global sea-level curve of Lambeck \& Chappell (2001). The start of stadials is defined by the onset of a sea-level fall and the end is defined by the midpoint between successive lowstands and highstands, in recognition of the lag in icesheet and sea-level response to warming. The Early Weichselian spans the interval from c. $118 \mathrm{kyr} \mathrm{BP}$ to $c$. $80 \mathrm{kyr}$ BP and corresponds to the two stadials MIS-5d and $5 \mathrm{~b}$ and the two interstadials MIS-5c and $5 \mathrm{a}$. The Middle Weichselian corresponds to the isotope stages MIS-4 and MIS-3 spanning the interval from c. $80 \mathrm{kyr}$ $\mathrm{BP}$ to $c .32 \mathrm{kyr}$ BP (see Fig. 3). As more information becomes available, the interstadials $5 \mathrm{c}$ and $5 \mathrm{a}$ reveal a more complex structure and each may consist of two or three relative highstands (Potter et al. 2004),

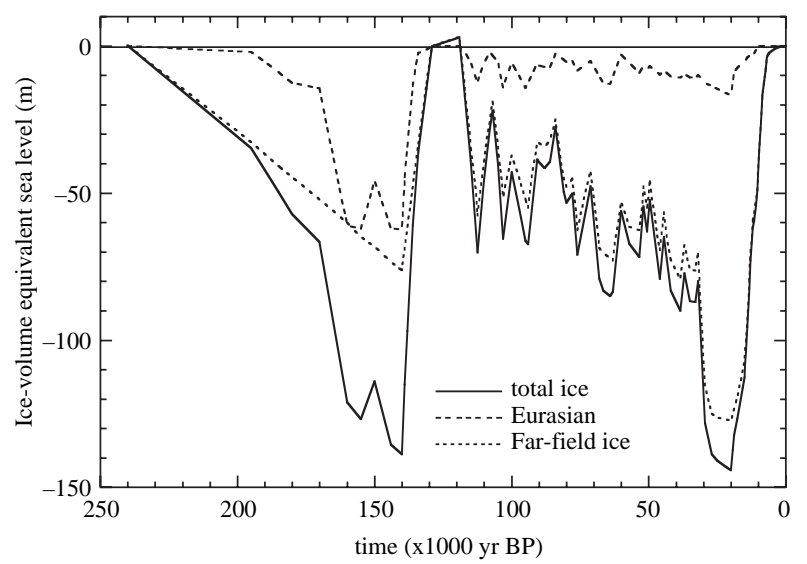

Fig. 3. The preliminary global ice-volume function, expressed as equivalent sea level (esl) adopted from Lambeck \& Chappell (2001) and Waelbroeck et al. (2002), and the components defining the Eurasian and far-field North America and Antarctica ice sheet contributions. implying that ice margins were not constant during these intervals, but we do not attempt to replicate this resolution here.

The Russian sector. - Two major post-Eemian glaciations of Early Weichselian and Middle Weichselian age have been identified between the Taymyr Peninsula and the Ural Mountains and from the Urals to the Kanin Peninsula in the European part of Russia (Svendsen et al. 2004) and the ice model developed here is based on that interpretation. A more recent investigation, however, has identified a more complex ice history for the latter area that suggests the ice margins during these stadials were closer to the present coast than adopted here (Larsen et al. 2006). Kjær et al. (2006) also demonstrated a split between the Middle Weichselian Barents and Kara Sea Ice sheets at the MIS-4-3 transition. At the end of the Eemian the Eurasian ice sheet appears to have formed initially over the arctic islands, then expanded and coalesced over the shallow Kara and Barents Seas before advancing southwards onto the Eurasian landmass (Hjort et al. 2004). In the east, it crossed the Byrranga Mountains on the Taymyr Peninsula and made contact with a separate ice sheet that formed over the Putorana Plateau. To the west, the ice crossed the northern end of the Ural Mountains and reached the Kanin Peninsula and Pechora lowlands. TL, OSL and ESR ages of marine and fluvial sediments associated with the deglaciation phase of this first ice advance fall mainly in the interval $100-80 \mathrm{kyr}$ $\mathrm{BP}$, although some of these ages, particularly the earlier determinations, may be too young. With the information currently available it does not appear possible to unambiguously associate this with either MIS-5d or MIS-5b, nor to establish whether this advance actually consisted of two comparable regional advances. Hence we have assumed that the ice sheet was similar for both stadials and that they were separated by a period of retreat (MIS-5c) consistent with evidence from local studies, such as across Taymyr (Möller et al. 1999; Hjort et al. 2004) or across the Pechora-Mezen region (Larsen et al. 2006). By MIS-5a the ice had retreated from much of the mainland, from Taymyr in the east, to north of the Urals, and from the Kanin Peninsula in the west, with residual ice confined to smaller ice caps on the shallow Kara Sea shelf and on the arctic islands, but also as buried ice in recessional ice-marginal zones in the south (cf. Alexanderson et al. 2002). Figure 2B$\mathrm{E}$ illustrates the adopted ice margins for the Early Weichselian advance $(5 \mathrm{~d}, 5 \mathrm{~b})$ and retreat $(5 \mathrm{c}, 5 \mathrm{a})$ phases.

The Scandinavian sector. - The adopted ice margins illustrated in Fig. 2 are based on the first author's reinterpretation of the field evidence from across Scandinavia; the details will be discussed elsewhere (but see also Lundqvist 2004; Mangerud 2004). In Norway during MIS-5d the ice margin is restricted to 
within the fjords, whereas during the next stadial MIS$5 \mathrm{~b}$ the ice approached the outer coast (Baumann et al. 1995; Sejrup et al. 2000; Mangerud 1981, 2004). The published interpretation of the evidence from northern Sweden (Lagerbäck \& Robertsson 1988; Robertsson \& Rodhe 1988; Lundqvist 1992, 2004; Robertsson et al. 1997), Finnmark (Olsen 1988; Olsen et al. 1996) and northern Finland (Hütt et al. 1993; Helmens et al. 2000), however, has not always been consistent across the three regions. There is agreement that there have been three main glacial events since the Eemian and the question has been whether these correspond to the two Early Weichselian glacials MIS-5d and $5 \mathrm{~b}$ and to a prolonged glacial period from MIS-4 to MIS-2 or whether there has been a period of limited ice cover during MIS-3. Independently of the above northern data there is a growing body of evidence that much of Scandinavia was ice-free during MIS-3, i.e. the Ålesund interstadial (Ukkonen et al. 1999; Olsen et al. 2001; Arnold et al. 2003) so that there would have been only two major glaciations in the Early and Middle Weichselian interval. Thus, together with the Norway evidence, the glaciation during MIS-5d is assumed to have been restricted to the high ground of Norway and Sweden and the first substantial post-Eemian glaciation of northern Scandinavia is assumed not to have occurred until MIS-5b. During the intervening interstadial (MIS-5c) the ice is assumed to have retreated back to mountain glaciers in Norway, as it did during MIS-5a. Such a model is largely consistent with an absence of Early Weichselian tills from the North Sea and with the ice movement across the Norwegian margin (Sejrup et al. 2000; Mangerud et al. 2004). It is also broadly consistent with the evidence from Denmark, southern Sweden, central-southern Finland, and Poland, although there remains much ambiguity in the chronology for the Early Weichselian (Berglund \& Lagerlund 1981; Robertsson 1988; Liivrand 1992; Mojski 1992; Lundqvist 1993; Nenonon 1995; Houmark-Nielsen 1999, 2004; Helmens et al. 2000; Marks 2004). In the northeast, the ice sheet is assumed to have remained independent of the Russian ice sheet during the first stadial (MIS-5d), but the two coalesced during the second stadial (MIS-5b) (Svendsen et al. 2004).

\section{Early Middle Weichselian}

The early Middle Weichselian is assumed to correspond to the period 80-62 kyr BP and to MIS-4. During this interval, average sea levels reached lower values than during the Early Weichselian and ice extent can be expected to have been substantial. But, as the global sea-level oscillations in this interval are also large, substantial ice-volume fluctuations can be anticipated across northern Eurasia within this stage.
The Russian sector. - After the interstadial phase MIS5a the ice sheet again expanded southwards, first over the shelf and islands and then onto the coastal plain in both Taymyr and to the west of the Urals. The maximum ice margins proposed by the QUEEN team (Svendsen et al. 2004) are adopted (Fig. 2F) and are attributed to an age of $65 \mathrm{kyr} \mathrm{BP}$, corresponding to the time of the lowest sea level during MIS-4. In the southwest the ice sheet extended across the Pechora and Mezen Lowlands, attaining its maximum postEemian southern limit in the Arkhangelsk region (Larsen et al. 2006) where it joined up with the Scandinavian Ice Sheet. In the east, the Kara Sea ice sheet regrew from ice remnants over Severnaya Zemlya (Möller et al. in press) and reached the North Taymyr ice-marginal zone (Hjort et al. 2004) north of the Byrranga Mountains. The Yamal and Gydan peninsulas were mostly ice-free at this time (Svendsen et al. 2004) and, depending on ice thickness and isostatic depression, these lowlands are potential sites for large ice-dammed lakes (Mangerud et al. 2004). Throughout the period, the ice sheet remained largely marine grounded and it could have been susceptible to rapid fluctuations in volume in response to either internal instabilities or to sea-level oscillations driven by mass fluctuations in the other major ice sheets.

The Scandinavian sector. - The maximum Early to Middle Weichselian model ice advance across Scandinavia occurs during MIS-4 with the ice sheet margins beginning to approach those for the subsequent LGM limits (Mangerud 2004). In Denmark, the advance is mainly restricted to the islands of Sjælland and Fyn, extending onto Djursland and the northern German plain (but see Ehlers et al. 2004). It has been suggested that there may have been two Middle Weichselian advances across the region (Houmark-Nielsen 1999), but we have not considered this option here because of the very limited sea-level information for this period and region with which the model can be constrained. The first full glaciation of Finland is assumed to have occurred after c. $75 \mathrm{kyr}$ BP, where the maximum advance during stage 4 is assumed to correspond to the Schalkholz stadial with a radiocarbon age of $>42$ kyr BP (Saarnisto \& Salonen 1995). In Norway, the ice sheet reached the continental margin (Mangerud 2004) at about the same time as the advance across central Denmark. Larsen et al. (2000) and Sejrup et al. (2000) also suggest that there may have been two Middle Weichselian advances, the chronology of which remains uncertain, and we have assumed that they correspond to the times of the sea-level lowstands at c. 64 (MIS-4) and the Late Middle Weichselian Jæren stadial at c. $40 \mathrm{kyr}$ BP. The first post-Eemian tills of Poland, the Older Vistulan (Mojski 1992) and the Mägiste of Estonia (Liivrand 1992), are also attributed to the MIS-4 advance. 


\section{Late-Middle and Late Weichselian}

The last substantial ice movement over arctic Russia is the retreat at the end of MIS-4 back to the Kara Sea and eventually back to the arctic islands such that after c. $55 \mathrm{kyr}$ the major land areas were and remained essentially ice-free. The Scandinavian ice sheet, however, continued to fluctuate throughout Stage 3, with at least two periods of extensive ice-free conditions corresponding to the $\mathrm{B} \varnothing$ interstadial (at $c .52 \mathrm{kyr} \mathrm{BP}$ ) when the ice retreated to northern Sweden, and the Ålesund interstadial (at c. $35 \mathrm{kyr}$ ), when much of Scandinavia may have been ice-free. At least one major advance (the Jæren-Klintholm-Skjonghelleren advance at c. 45-40 kyr BP) occurred in between these two interstadials (Olsen 1997; Larsen et al. 2000; Arnold et al. 2003; Houmark-Nielsen \& Kjær 2003). The LGM and post-LGM ice model adopted is that previously constrained by rebound data across Scandinavia and northern Europe (Lambeck et al. 1998b; Lambeck \& Purcell 2003).

\section{Ice thickness estimates}

It is generally accepted that for the Late Saalian ice to have advanced from the Arctic Ocean onto the Russian Plain to $c .50^{\circ}$ north latitude, its maximum elevation must have been in excess of $3 \mathrm{~km}$ (Denton \& Hughes 1981) or the ice thickness exceeded $4 \mathrm{~km}$. But there is no observational evidence to constrain the ice thickness and any estimates will be model dependent. To establish a starting model for the Saalian and Early and Middle Weichselian intervals we have assumed frozen basal conditions such that the ice elevation $H_{\max }$ at the centre of an ice sheet at the time $t_{\max }$ of maximum glaciation is given by (Paterson 1994)

$$
H_{\max }\left(t_{\max }\right)=\alpha s_{\max }^{1 / 2}
$$

where $s_{\max }$ is the distance of the ice margin from the centre. The coefficient $\alpha$ is give by

$$
\alpha=(2 \tau / \rho g)^{1 / 2}
$$

where $\tau$ is the basal shear stress, $\rho$ is the density of ice and $g$ is gravity. The parameter $\alpha$ will vary locally and regionally depending, inter alia, on the nature of the bedrock and the topography. The ice height at a distance $s$ along a profile radiating out from the centre of the ice sheet at time $t$ is defined as

$$
H(s, t)=H_{\max }(t)\left\{1-\left[\left(s(t) / s_{\max }(t)\right]^{3 / 2}\right\}^{0.4}\right.
$$

The following procedure has been used to determine the first approximation to ice elevations through time: (i) If the ice sheet is single domed, a nominal value $H_{\max }^{0}\left(t_{\max }\right)$ is adopted for the ice elevation at its centre of maximum elevation at time of maximum glaciation. For any profile radiating out from this centre $\alpha$ is estimated from $s_{\max }\left(t_{\max }\right)$ and $H_{\max }^{0}$ $\left(t_{\max }\right)$ using Eq. (1). Different profiles radiating from the centre may have different values for $\alpha$ depending on the distance $s_{\max }$ along the profile. The ice elevation $H\left(s, t_{\max }\right)$ along each profile at $t_{\max }$ is then determined from Eq. (3) as a function of $H_{\max }^{0}\left(t_{\max }\right)$.

(ii) For the subsequent epochs $t$ for which the ice margins and centre of rebound are known, assuming that any shift in the location of this centre has been small, $s_{\max }(t)$ is estimated along similar radial sections as $t_{\max }$ and, using the values for $\alpha$ evaluated at $t_{\max }$ for each profile, $H_{\max }(t)$ is established for each profile.

(iii) These latter estimates of $H_{\max }(t)$ may vary from profile to profile if retreat along different sections has occurred at different rates. In this case the mean value for all sections is adopted and new values for $\alpha$ are estimated for the profiles, implying that the basal conditions have evolved with time. The ice elevations along the profiles at $t$ follow from Eq. (3).

With this procedure, the ice elevations of the entire ice sheet are specified to within a scaling factor of

$$
\beta=H_{\max }\left(t_{\max }\right) / H_{\max }^{0}\left(t_{\max }\right)
$$

where $H_{\max }\left(t_{\max }\right)$ is the true (but unknown) value for the maximum ice elevation at $t_{\max }$.

If the ice sheet consists of two or more domes, then the same method is used separately for each dome for those profiles that do not radiate through the zone of confluence. For a two-domed ice sheet, for example, within each sector defined by the confluence zone the $s_{\max }$ values are assumed to vary linearly between the values for the bounding radials and the ice elevation is estimated separately within each sector. The intersection of the two height surfaces then determines the location and elevation of the saddle between the two domes.

Once the ice elevations $H(t)$ have been determined the ice thickness $I(t)$ is determined from

$$
I(t)=H(t)-h+u_{\mathrm{r}}(t)
$$

where $h$ is the height of present-day topography (negative if the ice is grounded below sea level) and $u_{\mathrm{r}}(t)$ is the isostatic radial rebound of the crust at epoch $t$ with respect to the present. This last quantity is calculated in an iterative way in which the first crustal rebound calculation is carried out with the ice load defined by $H(t)$. This provides the first-iteration 
estimate of $u_{\mathrm{r}}(t)$ and an improved estimate for the ice thickness.

We have adopted the Late Saalian ice sheet limits as the starting model with domes centred over Scandinavia and over the Kara arctic coast, but with a thick ice ridge joining the two. The nominal maximum ice elevation for both domes is $3200 \mathrm{~m}$ and the model is defined by two scaling parameters $\beta^{\mathrm{S}}$ and $\beta^{\mathrm{K}}$. Fig. $2 \mathrm{~A}$ illustrates the resulting ice sheet for the Late Saalian at the nominal epoch of $t=140 \mathrm{kyr}$. To define the ice sheet for epochs for which the ice margin is interpolated between observationally defined margins we note that the change in volume $\mathrm{d} V_{\mathrm{i}}$ along a radial (of unit width) at time $t$ is related to the distance of advance or retreat $\mathrm{d} s_{\max }$ as

$$
\mathrm{d} V_{\mathrm{i}} \approx \alpha \sqrt{s_{\max }} \mathrm{d} s_{\max } .
$$

Then, if we assume that the growth and decay of the major global ice sheets are in phase and that when major oscillations in sea level occur the proportional changes in these sheets are equal,

$$
\mathrm{d} s_{\max }=\left(\alpha \sqrt{s_{\max }}\right)^{-0.5} V_{\mathrm{i}} \delta \zeta_{\text {esl }} / \Delta \zeta_{\mathrm{esl}}
$$

where $V_{\mathrm{i}}$ is the total volume of the ice sheet and $\delta \zeta_{\text {esl }} /$ $\Delta \zeta_{\text {esl }}$ is the proportional change in the equivalent sea level (esl) at time $t$. This defines new ice margins for each epoch of interpolation and the ice thickness is predicted as before. Provided that the predictions for rebound and shoreline migration focus primarily on the epochs for which the margins are observationally known rather than for the interpolated intervals, then the outcomes should not be overly dependent on the approximations made in this interpolation model.

Global volumes and distribution of ice between major ice sheets

The global changes in ice volume from MIS- 6 to the present are specified by the ice-volume esl function of Lambeck \& Chappell (2001) and Waelbroeck et al. (2002), which quantifies the total volume of ice $V_{\mathrm{i}}$ locked up in the ice sheets, including ice grounded on the shallow shelves. During the Late Saalian the Eurasian ice sheet represents about $50 \%$ of the total ice volume, although during the later MIS-5 and 4 stadials, as well as during stage 2 , this fraction is much reduced. Changes in the Eurasian ice volume must thus have been compensated for by changes in the volumes of the ice sheets of North America and Antarctica, such that the ice-water mass is conserved. The principal contribution of these 'far-field' ice sheets to sea-level change across northern Eurasia is the esl part and this is equal to the difference between the global estimates of ice volume and the contribution from the Eurasian ice. The isostatic contributions from the distant ice sheets at locations far from the ice sources are typically $10-20 \%$ of the esl signal, and estimates of it require that the far-field ice be distributed between the component ice sheets.

Information on the pre-LGM glacial history of North America is limited (Clark et al. 1993; Kleman et al. 2002) and we adopt a simple approximation based on our current models for MIS-2. This assumes that if at any pre-LGM time $t^{\prime}$ the global esl value is equal to that for a post-LGM epoch $t^{\prime \prime}$, then $\Delta V_{\mathrm{i}}\left(t^{\prime}\right)=$ $\Delta V_{\mathrm{i}}\left(t^{\prime \prime}\right)$ for that particular ice sheet. Tests with alternative hypotheses about the pre-LGM ice sheet indicate that this simple assumption is adequate provided that predictions are restricted to localities beyond the North American ice margins. Any difference between the sum of the two northern hemisphere ice sheets and the global esl value is attributed to Antarctic Ice Sheet fluctuations. Figure 3 illustrates the resulting esl functions for the principal components: the Eurasian ice sheet and the far-field component comprising the North American, Antarctic, British ice sheets and mountain glaciers. We emphasize that, because the North American isostatic contribution to relative sealevel change over Eurasia is small, even a $50 \%$ uncertainty in the distribution of the far-field ice results in prediction uncertainties of only $5-10 \%$ of the esl change and this lies well within most observational accuracies for the pre-LGM interval.

\section{Rebound model and earth parameters}

The glacial rebound model used here has been described elsewhere (Nakada \& Lambeck 1987; Lambeck \& Johnston 1998; Lambeck et al. 2003) and has been used to model the glacial rebound of northern Europe and other regions. The elastic response of the earth is described by elastic moduli and density depth profiles that are determined from seismic analyses, while the viscous response is assumed to be linear and described as a Maxwell medium. A three-layer viscosity zonation is adopted, corresponding to a lithosphere of effective elastic thickness $H_{1}$, an upper mantle of average effective viscosity $\eta_{\mathrm{um}}$ and a lower mantle of average effective viscosity $\eta_{\mathrm{lm}}$, with the boundary of the two zones at $670 \mathrm{~km}$ depth. Such models have been found to describe well the Scandinavian rebound phenomenon of the past 20,000 years (Mitrovica 1996; Lambeck et al. 1998a, b; Milne et al. 2002). Table 2 summarizes the values adopted for the earth-model parameters and these correspond to values found satisfactory for the Late Weichselian and Holocene analyses (Lambeck et al. 1998b; Lambeck \& Purcell 2003). 
Table 2. Rheological parameters for the nominal earth-mantle model.

\begin{tabular}{cll}
\hline Elastic moduli and density & & $\begin{array}{l}\text { Dziewonski \& } \\
\end{array}$ \\
& & Anderson (1981) \\
Effective lithospheric thickness, & $H_{1}$ & $80 \mathrm{~km}$ \\
Effective lithospheric viscosity, & $\eta_{1}$ & $10^{25} \mathrm{~Pa} \mathrm{~s}$ \\
Effective upper mantle viscosity, & $\eta_{\mathrm{um}}$ & $3 \times 10^{20} \mathrm{~Pa} \mathrm{~s}$ \\
Depth of base of upper mantle & & $670 \mathrm{~km}$ \\
Effective lower mantle viscosity, & $\eta_{\operatorname{lm}}$ & $5 \times 10^{21} \mathrm{~Pa} \mathrm{~s}$ \\
\hline
\end{tabular}

\section{Observational constraints}

Observations of Eemian sea level across the previously glaciated region of northern Eurasia are too few and incomplete to contemplate a formal inversion for ice model parameters independent of glaciological or empirical considerations. But they do provide constraints on competing hypotheses for aspects of the former ice sheets such as the ice thickness or the timing of the retreat or advance. In this section, we review some of the available material from both the Russian and the Fennoscandian sectors. This evidence comes in two forms, the location of shorelines or simply the knowledge that a particular locality was above or below sea level for the epoch, and the observation that at a specified epoch sea level was above or below present level by a quantifiable amount.

\section{The Russian sector}

Table 3 summarizes observational constraints on Eemian and Early-Middle Weichselian sea levels from the Taymyr Peninsula. The Eemian data correspond mostly to warm-water marine sediments from a boreal period and we have assumed that they correspond to the pollen zones E2-E4 and were deposited a short time after the onset of the Interglacial and after the region became predominantly ice-free (Grøsfjeld et al. 2006). Marine inundation of the Taymyr Peninsula appears to have been widespread after the late Stage 6 ice retreat at c. $134 \mathrm{kyr} \mathrm{BP}$ and Last Interglacial sediments occur in many locations (Kind \& Leonov 1982; Hjort et al. 2004). The highest elevations of warm-water sediments from the Boreal interval of the Eemian have been reported along the Goltsovaya River, where they occur at $c .133 \mathrm{~m}$ above sea level (a.s.l.) as a regressive sequence (Gudina et al. 1983) (Table 3). Along Lake Taymyr they occur up to $c .90 \mathrm{~m}$ a.s.l. (Kind \& Leonov 1982) and along the Luktakh River, $230 \mathrm{~km}$ southwest of Lake Taymyr, they are also reported at $c .90 \mathrm{~m}$ a.s.l. To the north, on the Chelyushkin Peninsula, they occur at least $65-80 \mathrm{~m}$ a.s.l. (Svendsen et al. 2004; Hjort et al. 2004). Some of this spatial variability may be a consequence of incomplete observational records, of the observations corresponding to different times within the boreal Eemian period, or of a geographically variable Late
Saalian ice load, but, taken together, the observations point to widespread marine conditions up to at least $133 \mathrm{~m}$ a.s.l. and falling during the early Eemian between $c .132$ and $129 \mathrm{kyr} \mathrm{BP}$ and $c$. $2 \mathrm{kyr}$ after ice retreat from the area. Marine levels for the inundation following the Early Weichselian deglaciation have been reported at similar elevations along the Taymyr Lake basin (Möller et al. 1999; Hjort et al. 2004) and on the Chelyushkin Peninsula (Hjort et al. 2004). October Revolution Island, in the Severnaya Zemlya archipelago, experienced marine inundations following the Late Stage 6 and Middle Weichsellian glaciations, the former reaching $c .120-130 \mathrm{~m}$ a.s.l. and the latter c. $60-70 \mathrm{~m}$ a.s.l., and stratigraphic and chronologic data suggest that Severnaya Zemlya was never deglaciated in Stage 5 before Kara Sea ice-sheet growth in Stage 4 (Möller et al. in press). In the Agapa River system of southern Taymyr, marine sediments with warm-water fauna have also been identified at several localities (Gudina 1966; Gudina et al. 1968; Troitsky 1979). Sediments of Sanchugova age (possibly Late Saalian-Earliest Eemian) occur up to at least $117 \mathrm{~m}$ a.s.l. at Nizhnyaya Agapa, while Eemian sections have been identified at Lower Agapa (Gudina 1968).

Within the Yenisey River valley of West Siberia, early Eemian marine sediments occur at least as far south as $67^{\circ} \mathrm{N}$ and the maximum observed elevations become progressively higher from south to north (Sukhorukova 1999) (Table 3). However, it is emphasized in Svendsen et al. (2004) that the strata for the northern localities are often heavily glaciotectonized by the subsequent Early Weichselian glaciations and that it has not been possible to determine the upper limits of sea level, or that some of the sequences attributed to the Eemian transgression may actually correspond to an earlier interglacial. On the Taz Peninsula, Astakhov (1992) has identified Eemian sediments at elevations that also exhibit a strong north-south gradient. In addition, there is a general observation made by Svendsen et al. (2004) that at several localities on the Gydan and Yamal peninsulas cold-water marine sediments, post-dating the Last Interglacial, occur below $30-40 \mathrm{~m}$ elevation. Because water depths at time of deposition are unknown and because transitions from marine to terrestrial environments have not been identified, these estimates are considered here as lower limits only.

To the west of the Ural Mountains the lowland areas adjoining the Pechora region and the Barents and White Seas have been extensively inundated during the early Eemian - the 'Boreal Transgression'. For the Pechora Lowland, Svendsen et al. (2004) make a general observation that this transgression occurs up to $60 \mathrm{~m}$ a.s.l. Marine sediments corresponding to this interval also occur at c. $50 \mathrm{~m}$ along the Sula River (Mangerud et al. 1999) and this represents a lower limit to sea level for this locality. In the same area, the marine limit occurs at $>100 \mathrm{~m}$ a.s.l. The Boreal 
Table 3. Summary of observational evidence for Eemian to Middle Weichselian sea levels in Russia (Taymyr to Arkhangelsk).

\begin{tabular}{|c|c|c|c|c|c|c|}
\hline Region & Locality & $\begin{array}{l}\text { Approximate } \\
\text { coordinates }\end{array}$ & Evidence & Nominal age & $\begin{array}{l}\text { Elevation } \\
\text { (m a.s.l.) }\end{array}$ & Reference \\
\hline \multirow{7}{*}{ Taymyr Peninsula } & Goltsovaya River & $76.8^{\circ} \mathrm{N} 104.3^{\circ} \mathrm{E}$ & Boreal marine sediments & Early Eemian & 133 & Gudina et al. (1983) \\
\hline & Lake Taymyr & $74.5^{\circ} \mathrm{N} 101^{\circ} \mathrm{E}$ & $\begin{array}{l}\text { Delta sediments with cold-water } \\
\text { marine fauna }\end{array}$ & $\begin{array}{l}\text { Early Weichselian } \\
95-80 \mathrm{kyr} \mathrm{BP}\end{array}$ & $90-100$ & $\begin{array}{l}\text { Möller et al. (1999, 2002) } \\
\text { Hjort et al. (2004) }\end{array}$ \\
\hline & Lake Taymyr & $74.5^{\circ} \mathrm{N} 102.5^{\circ} \mathrm{E}$ & Laminated sand-silt sediments & Eemian & 90 & Kind \& Leonov (1982) \\
\hline & Bolshaya Rassokha River & $74.1^{\circ} \mathrm{N} 105.3^{\circ} \mathrm{E}$ & Marine deposits & Early Eemian & $>70$ & Kind \& Leonov (1982) \\
\hline & Luktakh River & $73.5^{\circ} \mathrm{N} 93.5^{\circ} \mathrm{E}$ & Coastal marine facies & Eemian & 90 & Svendsen et al. (2004) \\
\hline & Chelyuskin & $77.5^{\circ} \mathrm{N} 104^{\circ} \mathrm{E}$ & Interglacial marine sediments & Eemian & $>65-80$ & Svendsen et al. (2004) \\
\hline & & & Beach sediments & Early Weichselian 93-80 kyr BP & $>65-80$ & Hjort et al. (2004) \\
\hline \multirow[t]{2}{*}{ Severnaya Zemlya } & October Revolution Island & $79.3^{\circ} \mathrm{N} 98^{\circ} \mathrm{E}$ & Marine transgression & Early Eemian & $120-130$ & $\begin{array}{l}\text { Bolshiyanov \& Makeyev (1995) } \\
\text { Möller et al. (2006) }\end{array}$ \\
\hline & & & Marine transgression & Middle Weichselian 60-50 kyr BP & $60-70$ & Möller et al. (2006) \\
\hline \multirow[t]{2}{*}{ Southern Taymyr } & Nizhnyaya Agapa & $70.2^{\circ} \mathrm{N} 86.8^{\circ} \mathrm{E}$ & Falling sea level & Latest Saalian Earliest Eemian & $>117$ & Gudina et al. (1968) \\
\hline & Lower Agapa & $71.6^{\circ} \mathrm{N} 88.3^{\circ} \mathrm{E}$ & Cold-water post-Boreal fauna & Late Eemian & 60 & Gudina et al. (1968) \\
\hline \multirow[t]{5}{*}{ West Siberia } & Yenisey Bay & $72^{\circ} \mathrm{N} 84^{\circ} \mathrm{E}$ & Marine sediments with boreal fauna & Eemian & $>64$ & Sukhorukova (1999) \\
\hline & Yenisey River & $67^{\circ} \mathrm{N} 87^{\circ} \mathrm{E}$ & Marine sediments with boreal fauna & Eemian & $>5$ & Sukhorukova (1999) \\
\hline & Taz Peninsula & $68^{\circ} \mathrm{N} 75^{\circ} \mathrm{E}$ & Marine boreal sediments & Eemian & $60-80$ & Astakhov (1992) \\
\hline & & $66^{\circ} \mathrm{N} 75^{\circ} \mathrm{E}$ & Marine boreal sediments & Eemian & $>10$ & Astakhov (1992) \\
\hline & Gydan-Yamal peninsulas & $71^{\circ} \mathrm{N} 74^{\circ} \mathrm{E}$ & $\begin{array}{l}\text { Undeformed marine silts with } \\
\text { cold-water fauna }\end{array}$ & Early or Middle Weichselian & $>30-40$ & Svendsen (2004) \\
\hline \multirow[t]{2}{*}{ Pechora Lowlands } & Pechora-Sula rivers & $66.9^{\circ} \mathrm{N} 50.2^{\circ} \mathrm{E}$ & Marine boreal fauna & Early Eemian & $>50$ & Svendsen et al. (2004) \\
\hline & & & Marine limit & Latest Saalian & $>100$ & Mangerud et al. (1999) \\
\hline \multirow[t]{10}{*}{ Arkhangelsk area } & Kanin, Tarkhanov & $68.5^{\circ} \mathrm{N} 43.8^{\circ} \mathrm{E}$ & Shoreface sediments & Eemian & 137 & Funder (unpublished) \\
\hline & Kanin, Tobuyev & $68.6^{\circ} \mathrm{N} 43.8^{\circ} \mathrm{E}$ & Shoreface sediments & Eemian & $>115$ & Funder (unpublished) \\
\hline & North Kanin coast & $68.3^{\circ} \mathrm{N} 44.4^{\circ} \mathrm{E}$ & Tidal sediments & Early Weichselian & $<0$ & $\begin{array}{l}\text { Kjær et al. }(2006) \\
\text { Larsen et al. }(2006)\end{array}$ \\
\hline & Mezen Bay & $66.1^{\circ} \mathrm{N} 44.2^{\circ} \mathrm{E}$ & Subtidal sediments & Early-Middle & $15-25$ & Jensen et al. (2006) \\
\hline & Cape Tolstik & & & Weichselian 60 kyr BP & & Kjær et al. (2003) \\
\hline & Pyoza River & $65.8^{\circ} \mathrm{N} 47.7^{\circ} \mathrm{E}$ & $\begin{array}{l}\text { Marine boreal shoreface/ } \\
\text { foreshore sediments }\end{array}$ & Early Eemian & $>63$ & $\begin{array}{l}\text { Houmark-Nielsen et al. (2001) } \\
\text { Grøsfjeld } \text { et al. (2006) }\end{array}$ \\
\hline & & & Marine limit & Late Saalian & 100 & \\
\hline & Dvina basin & $64^{\circ} \mathrm{N} 41^{\circ} \mathrm{E}$ & Marine boreal fauna & Eemian & $>40$ & Svendsen et al. (2004) \\
\hline & Vaga River Pasva & $61.1^{\circ} \mathrm{N} 42.1^{\circ} \mathrm{E}$ & Marine boreal fauna & Early Eemian & $>52$ & Larsen et al. (1999b) \\
\hline & Dvina basin & & & & & Lyså et al. (2001) \\
\hline
\end{tabular}


Table 4. Summary of observational evidence for Eemian to Middle Weichselian sea levels in northern Europe (Karelia to North Sea).

\begin{tabular}{|c|c|c|c|c|c|c|}
\hline Region & $\begin{array}{l}\text { Approximate } \\
\text { coordinates }\end{array}$ & Evidence & Pollen zone & $\begin{array}{l}\text { Nominal age } \\
\text { (kyr BP) }\end{array}$ & $\begin{array}{l}\text { Elevation } \\
\text { (m a.s.l.) }\end{array}$ & Reference \\
\hline \multirow[t]{2}{*}{ Petrozavodsk, Lake Onega } & \multirow[t]{2}{*}{$61.8^{\circ} \mathrm{N} 34.3^{\circ} \mathrm{E}$} & Start of marine inundation & E2a & 132.4 & $>40$ & \\
\hline & & End of marine inundation & $\mathrm{E} 4 \mathrm{~b}$ & 130 & $>40$ & Funder et al. (2002) \\
\hline \multirow{3}{*}{$\begin{array}{l}\text { Continental water shed } \\
\text { (Povenets, Lake Onega) } \\
\text { Neva Lowlands, Mga }\end{array}$} & \multirow[t]{2}{*}{$62.9^{\circ} \mathrm{N} 34.8^{\circ} \mathrm{E}$} & \multirow[t]{2}{*}{ Marine Eemian sediments } & \multirow[t]{2}{*}{$\mathrm{E} 2 \mathrm{~b}$ to $\mathrm{E} 4 \mathrm{~b}$} & \multirow[t]{2}{*}{$132-130$} & >140@132 kyr BP & \\
\hline & & & & & $\begin{array}{l}>105 @ 130 \text { kyr BP } \\
>20-40\end{array}$ & $\begin{array}{l}\text { Funder et al. (2002) } \\
\text { Funder et al }\end{array}$ \\
\hline & $59.5^{\circ} \mathrm{N} 34.8^{\circ} \mathrm{E}$ & $\begin{array}{l}\text { Start of inundation } \\
\text { End of inundation }\end{array}$ & $\begin{array}{l}\text { E2a } \\
\text { E6b }\end{array}$ & $\begin{array}{l}132.3 \\
122.5\end{array}$ & $>20-40$ & $\begin{array}{l}\text { Funder et al. (2002) } \\
\text { Znamenskaia \& Cherminisova } \\
\text { (1962) }\end{array}$ \\
\hline \multicolumn{7}{|l|}{ Ostrobothnia } \\
\hline Evijärvi & $63.4^{\circ} \mathrm{N} 23.5^{\circ} \mathrm{E}$ & Marine to freshwater transition & $\mathrm{E} 3 \mathrm{~b}-\mathrm{E} 4 \mathrm{a}$ & 131 & 61 & Eriksson (1993) \\
\hline Vesiperä & $64.1^{\circ} \mathrm{N} 25.2^{\circ} \mathrm{E}$ & Marine to freshwater & $\mathrm{E} 2$ & 132.2 & 103 & $\begin{array}{l}\text { Eriksson (1993) } \\
\text { Nenonen (1995) }\end{array}$ \\
\hline Ollala & $64.2^{\circ} \mathrm{N} 25.3^{\circ} \mathrm{E}$ & Marine to freshwater & & 132.4 & 116 & Saarnisto \& Salonen (1995) \\
\hline Kärsämäki & $64.0^{\circ} \mathrm{N} 25.7^{\circ} \mathrm{E}$ & Marine to freshwater & & 132.1 & 106 & Saarnisto \& Salonen (1995) \\
\hline Norinkylä & $62.5^{\circ} \mathrm{N} 21.7^{\circ} \mathrm{E}$ & Marine to freshwater & & 132.2 & 112 & Saarnisto \& Salonen (1995) \\
\hline Peräseinäjoki & $62.4^{\circ} \mathrm{N} 22.2^{\circ} \mathrm{E}$ & Marine to freshwater & & 131.4 & 89 & Nenonen (1995) \\
\hline \multicolumn{7}{|l|}{ Kola Peninsula } \\
\hline (1) Ponoi River & $67.4^{\circ} \mathrm{N} 37.2^{\circ} \mathrm{E}$ & Upper limit of marine sediments & & 129 & 130 & Lavrova (1960) \\
\hline (2) Bab'ya & $66.5^{\circ} \mathrm{N} 40.7^{\circ} \mathrm{E}$ & Upper limit of marine sediments & & 129 & 129 & Lavrova (1960) \\
\hline (3) Ust Pyalka & $66.7^{\circ} \mathrm{N} 41.0^{\circ} \mathrm{E}$ & Upper limit of marine sediments & & 129 & 127 & Lavrova (1960) \\
\hline (4) Sosnovki & $66.8^{\circ} \mathrm{N} 40.5^{\circ} \mathrm{E}$ & $\begin{array}{l}\text { Upper limit of marine sediments } \\
\text { First occurrence of carpinus }\end{array}$ & \multirow[t]{5}{*}{ E5 } & 129 & 126 & Lavrova (1960) \\
\hline (5) Pyalitsa & $66.4^{\circ} \mathrm{N} 39.5^{\circ} \mathrm{E}$ & Upper limit of marine sediments & & 129 & 92 & Lavrova (1960) \\
\hline (6) Varsuga & $66.5^{\circ} \mathrm{N} 36.3^{\circ} \mathrm{E}$ & Upper limit of marine sediments & & 129 & 60 & Lavrova (1960) \\
\hline (7) Pakhten & $67.1^{\circ} \mathrm{N} 41.1^{\circ} \mathrm{E}$ & $? ?$ & & 129 & 120 & Gudina \& Evzerov (1981) \\
\hline (8) Malaya Kachkovka & $67.4^{\circ} \mathrm{N} 40.9^{\circ} \mathrm{E}$ & $? ?$ & & 129 & 140 & Gudina \& Evzerov (1981) \\
\hline Central Sweden, Dellen & $61.8^{\circ} \mathrm{N} 16.7^{\circ} \mathrm{E}$ & Marine littoral phase & Late Eemian & 127 & $\sim 30$ & Robertsson et al. (1997) \\
\hline Central Sweden, Bollnäs & $61.3^{\circ} \mathrm{N} 16.3^{\circ} \mathrm{E}$ & $\begin{array}{l}\text { Brackish to brackish-marine } \\
\text { Flora }\end{array}$ & Eemian optimum & \multirow[t]{3}{*}{$132-130$} & $>88$ & Garcia Ambrosiana (1990) \\
\hline Southern Sweden, Stenberget & $55.5^{\circ} \mathrm{N} 13.6^{\circ} \mathrm{E}$ & Terrestrial vegetation & Eemian optimum & & $<160$ & Berglund \& Lagerlund (1981) \\
\hline Northern Sweden, Boliden & $64.9^{\circ} \mathrm{N} 20.3^{\circ} \mathrm{E}$ & Sand, silt and organic matter & $\begin{array}{l}\text { Eemian cool period } \\
\text { or early Weichselian }\end{array}$ & & $<204$ & $\begin{array}{l}\text { Robertsson \& Garcia } \\
\text { Ambrosiana (1988) }\end{array}$ \\
\hline \multirow[t]{3}{*}{ Western Norway, Fjøsanger } & \multirow[t]{3}{*}{$60.2^{\circ} \mathrm{N} 05.3^{\circ} \mathrm{E}$} & Start of Eemian above & & 135 & $35-55$ & Mangerud et al. (1981) \\
\hline & & Boreal marine & $E 3 b-E 4 a$ & $132-130$ & $25-45$ & \\
\hline & & End Eemian-earliest Weichselian & & 119 & $18-23$ & \\
\hline \multirow[t]{2}{*}{ Western Baltic, Vistula Valley } & \multirow[t]{2}{*}{$54.5^{\circ} \mathrm{N} 19^{\circ} \mathrm{E}$} & Start of inundation & E3a & 132 & \multirow[t]{5}{*}{$>20$} & Funder et al. (2002) \\
\hline & & End of marine phase & E6a & 124 & & Drozdowski (1988) \\
\hline Riga Bay, coastal Latvia and & $57.5^{\circ} \mathrm{N} 22^{\circ} \mathrm{E}$ & Cold-water brackish facies & Late Saalian & $>133$ & & \\
\hline Prangli & & & Early Weichselian & $<120$ & & Funder et al. (2002) \\
\hline \multirow[t]{3}{*}{$\begin{array}{l}\text { Schleswig-Holstein } \\
\text { (Schleswig-Holstein Canal) }\end{array}$} & \multirow[t]{3}{*}{$54.2^{\circ} \mathrm{N} 9.5^{\circ} \mathrm{E}$} & $\begin{array}{l}\text { Transition from limnic to brackish to } \\
\text { marine }\end{array}$ & $\mathrm{E} 1-\mathrm{E} 4 \mathrm{~b}$ & $132.5-129$ & & \\
\hline & & $\begin{array}{l}\text { Peak in marine inundation } \\
\text { Kosack \& Lange (1985) }\end{array}$ & $\mathrm{E} 3 \mathrm{~b}-\mathrm{E} 4 \mathrm{~b} / \mathrm{E} 5$ & $131.5-129.5$ & -4 to +8 & Kosack \& Lange (1985) \\
\hline & & $\begin{array}{l}\text { Transition from marine to Brackish } \\
\text { to limnic }\end{array}$ & $\begin{array}{l}\text { Late E5 and } \\
\text { E6a-E6b }\end{array}$ & $129-120$ & & \\
\hline \multirow[t]{2}{*}{ Denmark, Ristinge klint } & \multirow[t]{2}{*}{$55^{\circ} \mathrm{N} 10^{\circ} \mathrm{E}$} & Start of marine inundation & E3a & 132 & & Funder et al. (2002) \\
\hline & & End of inundation phase & E5 & 127 & & \\
\hline North Sea Amsterdam & $52.0^{\circ} \mathrm{N} 4.9^{\circ} \mathrm{E}$ & & E3b & 131.5 & $-16.3 \pm 5.8$ & Zagwijn (1996) \\
\hline
\end{tabular}


sediments are underlain by silts and clays that are characterized by cooler marine mollusc fauna of the Late Saalian/earliest Eemian period. From the sedimentary succession, Mangerud et al. (1999) suggested that an early period of emergence was interrupted by (eustatic) sea-level rise until emergence again became dominant.

On the Kanin Peninsula, shoreface sediments of early Eemian age occur in two locations at elevations of 137 and $>115 \mathrm{~m}$ a.s.l., respectively (Kjær et al. 2006), but the relative chronology within the interglacial is unknown. In the same region, Early Weichselian tidal sediments occur near present-day sea level (Larsen et al. 2006). Tidal sediments with a mean OSL date of c. $60 \mathrm{kyr}$ BP have been identified at Cape Tolstik in the Mezen River estuary at up to $13.5 \mathrm{~m}$ a.s.l. and if the palaeo-tidal range is assumed to be the same as the modern range, the inferred local sea level is at least $15 \mathrm{~m}$ above present (Kjær et al. 2003; Jensen et al. 2006). The most detailed record of Eemian hydrographical changes and sea-level history in northern Russia is from the Pyoza River valley, where Late Saalian and early Eemian marine sediments occur up to $65 \mathrm{~m}$ a.s.l. (Grøsfjeld et al. 2006). The Late Saalian deglacial marine limit here is $c .100 \mathrm{~m}$ a.s.l. The pollen analytically dated Saalian/Eemian boundary is marked by the onset Atlantic water inflow, and - as in the Pechora basin - the early Eemian is characterized by sea level rise, which in pollen zone E4 turned to regression (Grøsfjeld et al. 2006). To the south, in the Dvina basin, Eemian marine sediments occur at up to $c .40 \mathrm{~m}$ a.s.l. (Funder, unpublished). Further south, at Pasva in the Vaga River valley and outside the LGM ice margin the sediments occur up to $52 \mathrm{~m}$ a.s.l. (Larsen et al. 1999b; Lyså et al. 2001; Funder et al. 2002), pollen dated to a short interval in the early Eemian.

\section{The northern Europe sector}

Observational evidence from Europe is dominated by the timing of marine transgressions and/or regressions

Fig. 4. Predicted sea levels for selected sites. Periods of glaciation for the nominal model are grey shaded and periods when the ice margin stood near the site are shown by the grey-patterned shading. Where shown, the interval marked by the horizontal hachure corresponds to the time of observational data. The observed elevations are identified by the thick horizontal lines and the vertical arrows identify limiting values. The predictions are for the nominal ice model with different scaling factors applied. A. Goltsovaya River, Taymyr $(\beta=1.2,1.0$, $0.8)$. B. Chelyushkin $(\beta=1.0,0.8,0.6)$. C. October Revolution Island. D. Agapa localities. E. North and south Taz Peninsula for $\beta=0.8$. F. Kanin Peninsula $(\beta=1.0,0.8,0.6)$. G. Pasva, Dvina Basin. H. Karelia watershed near Povenets. I. Evijärvi, Ostrobothnia $(\beta=1.0$, $0.8,0.6)$. The inset is for an expanded scale about the time of the Eemian. J. Bollnäs and, inset, Dellen, Sweden $(\beta=1.0,0.8,0.6)$. K. Fjøsanger. L. Amsterdam ( $\beta=1.0)$, where the observations have been corrected for tectonic subsidence, compaction and differential isostasy. $\Delta \mathrm{T}$ is the correction to the nominal Eemian time scale. 

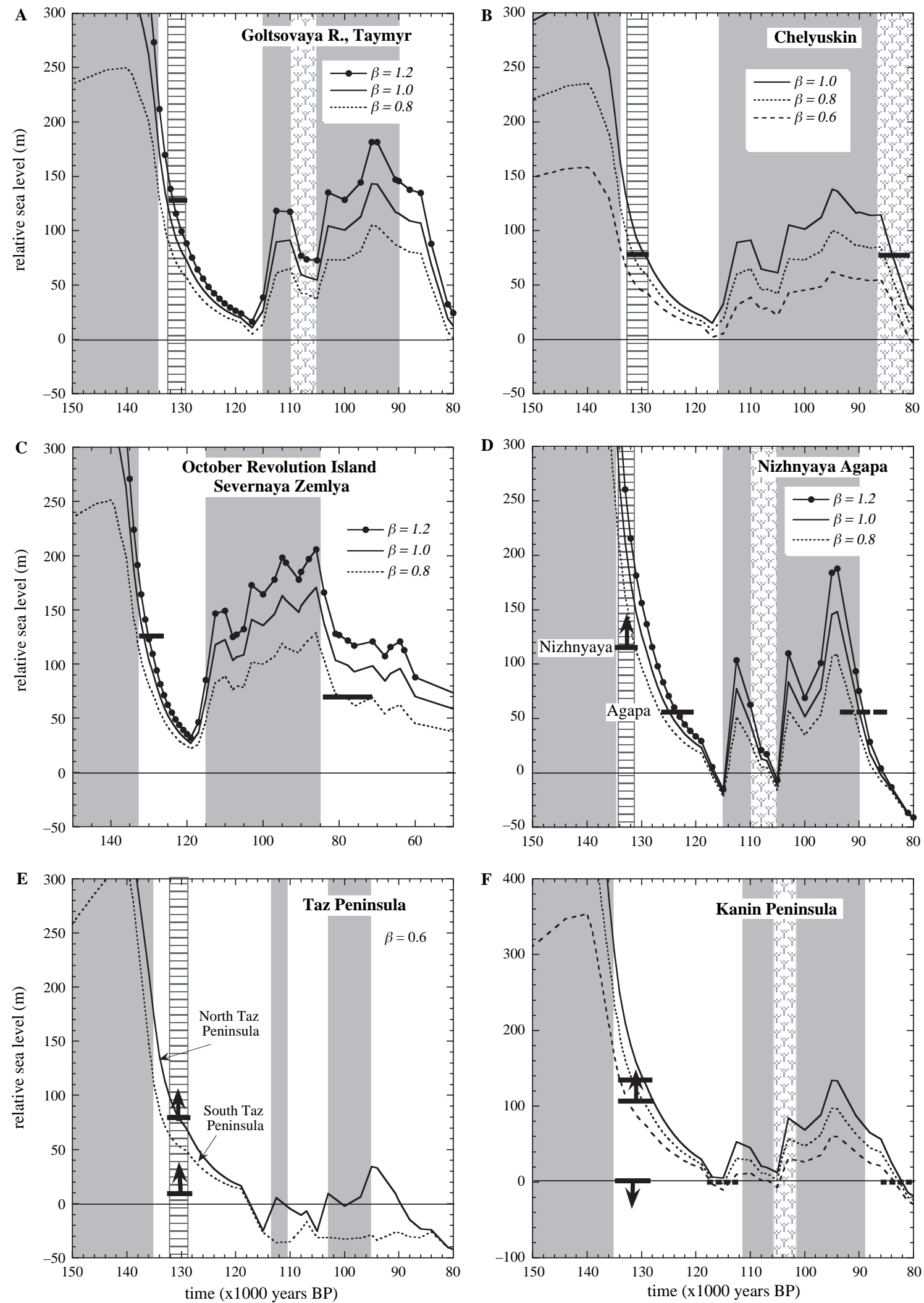

Fig. 4 (Continued) 

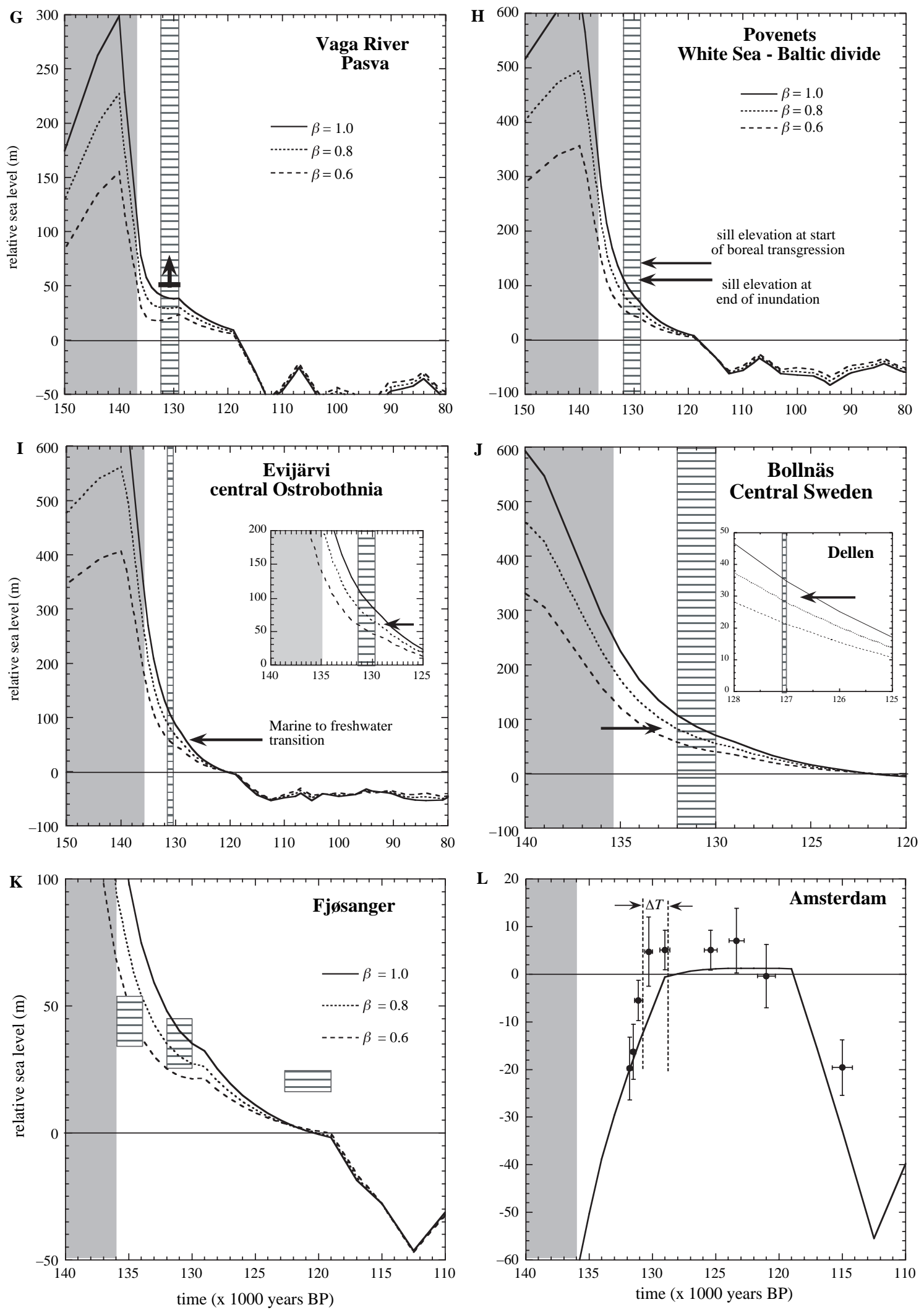

Fig. 4 (Continued) 
within warm-water marine sediments from the early Eemian period. Thus, they do not register the time of deglaciation and there are few, if any, observations of the marine limit at the time of deglaciation. As for the Russian data, the main interpretational problem is that water depth at the time of sediment deposition is generally not known and only lower limits to sea level can be inferred. Much of this information has been reviewed by Funder et al. (2002) and is reflected in the discussion below. In addition to the shoreline location results, there are some important sites where the transitions from marine to terrestrial depositional environments have been identified, particularly from Ostrobothnia, where it has also been possible to estimate elevations of former shorelines within a relative Eemian chronology. Table 4 summarizes the results used here.

In Petrozavodsk on Lake Onega, interglacial sediments have formed a continuous sequence from glaciolacustrine clays to marine sediments and lacustrine sand and till, with the marine boreal phase starting during the E2a zone and ending during either $\mathrm{E} 4 \mathrm{a}$ or E4b. The watershed between the Baltic and White Seas lies to the north of Lake Onega and occurs at a minimum elevation of $c .105 \mathrm{~m}$ a.s.l. Eemian sediments, with a richer fauna than is found in the Petrozavodsk cores and in clay pits around St. Petersburg, occur on the watershed at elevations of up to at least $101 \mathrm{~m}$ a.s.l. and this has been used as evidence that the White Sea flowed over the threshold and into the Onega basin for a period of up to $3 \mathrm{kyr}$ from E2a to E4b or from 132.4 to 129.5 for the preliminary time scale (Table 1). In this interval, soon after ice removal, isostatic rebound is expected to be rapid for the class of ice models discussed above and the water level at the start of the E2a period would have been about $30-40 \mathrm{~m}$ higher than at the end of E4b (Fig. 4H). Hence a lower limit along the watershed at $c .132 \mathrm{kyr}$ is $c .140 \mathrm{~m}$ a.s.l. In the Neva lowlands the first record of the boreal marine transgression is in the zone E2a and inundation persisted until E6b with water becoming more brackish early in zone E5. At Mga, near St Petersburg, varved clays occur at up to at least $-49 \mathrm{~m}$ a.s.l. and these are overlain by marine Eemian deposits. Water depths at time of deposition are unknown, but anoxic conditions interrupted by short periods of oxygenation have been interpreted as indicative of water depths of $c .80-100 \mathrm{~m}$ (Znamenskaia \& Cherminisova 1962) and we adopt an estimate for the Eemian sea level of $>20-40 \mathrm{~m}$.

The evidence from Ostrobothnia is more satisfactory than elsewhere because at several localities Saalian tills are overlain by clay deposits that contain freshwater or marine diatoms, followed by interglacial materials with the characteristic warm-water Eemian fauna or flora (e.g. Saarnisto \& Salonen 1995; Nenonen 1995) and generally the sequence of lagoonal, isolation and marine phases seen in the post-LGM record are also seen in this Saalian to Eemian transition (Nenonen
1995). The type locality in Ostrobothnia is at Evijärvi, where the interglacial record is one of marine silts followed in sequence by lagoonal gyttja and tills (Eriksson 1993). The pollen record indicates warmer conditions than during the Holocene and we assume that the end of the marine phase occurred at the end of E3b or during E4a at c. $131 \mathrm{kyr}$ BP. At Vesiperä, sand and clay deposits in a brackish-marine environment occur beneath an organic layer at $103 \mathrm{~m}$ a.s.l. (Eriksson 1993; Nenonen 1995) and from its pollen record we attribute it to the E2 pollen zone at c. 132.2 kyr BP. The highest known marine interglacial deposit with a transition to freshwater gyttja occurs in Ollala at $116 \mathrm{~m}$ a.s.l. and is at least $20 \mathrm{~m}$ above the highest nearby Litorina level. Similar isolations have been identified at Kärsämäki and Norinkylä (Eriksson 1993). At Peräseinäjoki, at $89 \mathrm{~m}$ a.s.l., the post-Saalian deposits begin in a freshwater clay containing diatoms that are similar to those found in the Holocene Ancylus Lake deposits. Likewise, at Norinkylä and elsewhere, freshwater silts occur below the marine horizons and this has led to the suggestion that the Baltic Sea basin began as a freshwater phase (Grönlund 1991a, b), although in the southern and western Baltic this early phase appears to be of a brackish nature. For these Ostrobothnia locations, the differential rebound during the Last Interglacial is small because the ice model for the Late Saalian is centred over this region and we therefore use the predicted gradients of sea-level rise at the other sites to establish the timing of the isolations at the other sites relative to that at Vesiperä (Table 4). This places the transitions in the pollen zones E2a to E3b.

On the Kola Peninsula marine sediments of Eemian age are widespread and estimates of the elevations of the tops of the sequences range from up to $150 \mathrm{~m}$ a.s.l. in the northeast (Molodkov \& Yevzerov 2004) to c. 120-140 $\mathrm{m}$ a.s.l. on the east coast and the centre of the peninsula (Ponoi; Table 4) (Lavrova 1960; Gudina \& Yevzerov 1973) and to $c .60 \mathrm{~m}$ a.s.l. on the south coast (Varsuga; Table 4) (Lavrova 1960). At Sosnovki, Carpinus pollen makes its first appearance in the sequence and we attribute an age of $c .129 \mathrm{kyr}$ (early pollen zone E5) to these sediments and assume that the other marine deposits are of comparable age. Molodkov \& Yevzerov (2004) note that interglacial warmperiod marine sediments also occurred in the central part of the peninsula (Lavrova 1960; site Kola Peninsula 2 in Table 4); that a large part of the peninsula was inundated and that sea levels reached their maximum elevations during the Late Saalian.

Marine Eemian sediments have been identified at only a few locations in Sweden. In central Sweden, at Lake Dellen (elevation c. $45 \mathrm{~m}$ a.s.1.), sediments with a pollen content that is consistent with the E5-E6 zone and with the onset of climate deterioration have been identified at a depth of $c .16-18 \mathrm{~m}$ in the core (Robertsson et al. 1997). The lower part of the 
sequence contains a brackish-marine flora, while the upper part accumulated in a freshwater environment. Thus, the observation adopted here is of a transition from brackish to freshwater at an elevation of c. $30 \mathrm{~m}$ a.s.l. during E5 or about $127 \mathrm{kyr}$ BP. At Bollnäs, an interglacial record at $88 \mathrm{~m}$ a.s.l. indicates brackish-water conditions at the time of relatively warm conditions (Garcia Ambrosiana 1990) and a nominal age of $132-130 \mathrm{kyr}$ has been adopted. The Stenberget observation of a nearly complete record of terrestrial vegetation for the entire Eemian (Berglund \& Lagerlund 1981) has been included here as an upper limiting value to sea level: local levels must have been below $160 \mathrm{~m}$ a.s.1. throughout the Eemian. The observation from Boliden is also a limiting value. The record is from $204 \mathrm{~m}$ a.s.l., below the Late Weichselian highest shoreline at $240 \mathrm{~m}$ and above the Litorina limit at $c .115 \mathrm{~m}$ a.s.1., and appears to have been deposited in a lacustrine or fluvial environment. Its age is uncertain, the pollen record being consistent with the cool climate conditions of either an Early Weichselian period or of a cool phase during the Eemian (Robertsson \& Garcia Ambrosiana 1988) and we use it here only as an upper limit.

From Norway we use one record from Fjøsanger, where Mangerud et al. (1981) have identified a complete succession of marine Eemian sediments including a Boreal phase, preceded by Late Saalian cold-water sediments and overlain by Early Weichselian deposits. Three sea-level estimates have been inferred from these data (Table 4); (i) the earliest sediments over Saalian tills are indicative of a cold water environment and are given a nominal age of $134 \mathrm{kyr}$ BP; (ii) the relative pollen chronology of the boreal sediments is correlated to the pollen zones of Table 1 and the Quercus-Corylus peak identified in the Fjøsanger data is attributed to zones E3a to E4a; (iii) the earliest Weichselian deposits overlying the Eemian sequence without apparent interruption are given a nominal age of $119 \mathrm{kyr}$ BP. The sea-level estimates for these periods are from Fig. 49 of Mangerud et al. (1981). The transgressive phase suggested in this figure, occurring in a pollen zone that could be correlated with E2b-E3a, is of short duration if the correlation is valid and we ignore it here.

In the western Baltic, the lower Vistula valley was inundated by the sea up to $70 \mathrm{~km}$ inland from its present mouth, with the Eemian marine episode beginning in the E3a pollen zone and lasting into E6a with salinity dropping towards the end of E5. The top of these marine deposits occurs up to 5-20 m a.s.1. (Drozdowski 1995; Drozdowski \& Federowicz 1987) and we adopt this as a lower limit to sea level during the early part of the Eemian. Further east, at Prangli (near the mouth of the Gulf of Finland) as well as in Riga Bay and coastal Latvia, marine sediments cover the entire Eemian, beginning and ending with cold-water brackish facies of Late Saalian and Early Weichselian ages, respectively, and with 'normal marine' conditions in the early Eemian, but no useful limiting estimates of sea level appear to be available.

From the Wadden Sea to the North Friesian Islands, the Eemian sedimentary sequence represents a complete transgressive-regressive cycle (Menke 1985; Funder et al. 2002; Funder \& Balic-Zunic 2006) that in locations such as Schleswig-Holstein and southern Denmark can be placed within the pollen zone sequence. Also, it has been suggested that during the early Eemian a seaway existed from the North Sea to the Baltic, in the vicinity of the present North SeaBaltic Sea canal (Kosack \& Lange 1985). These observations may be particularly useful because they are from sites outside the LGM ice margin and are least likely to have been disturbed. Here, Eemian sediments occur at $c$. $-13 \mathrm{~m}$ a.s.1. and greatest water depths at the time of persistent open-marine conditions are estimated to have been from 10 to $20 \mathrm{~m}$ in a pollen zone that can be correlated with E4a to early E5 of Zagwijn (1996). Hence we adopt a Schleswig-Holstein sea level of between -4 and $8 \mathrm{~m}$ during the interval 131.5-129.5 kyr BP (see Table 4). The evidence from Ristinge klint in southern Denmark gives a similar result of a transgressive phase followed by the regressive phase after the climate optimum (Funder et al. 2002), but estimates of the actual levels are all lower limits.

In Table 4, the chronology for the North Sea and Netherlands data described by Zagwijn $(1983,1996)$ is referenced to the chronology discussed above and the elevations have been corrected for tectonic subsidence and sediment compaction using the estimates from Kooi et al. (1998). The accuracy estimates include the uncertainties in these corrections. These results will be discussed elsewhere, but one point worth emphasizing is that within the uncertainties, and ignoring any differential isostatic contributions, sea levels in the area remained near a constant value from about $130 \mathrm{kyr}$ to $122 \mathrm{kyr} \mathrm{BP}$, and the fall in level seen in the uncorrected Zagwijn data can be largely attributed to a lower rate of tectonic subsidence/compaction at Amersfoort and Amsterdam than at the other localities (Kooi et al. 1998; fig. 4L).

Taken together, these observations point to a rising level in the North Sea during the Late Saalian and the earliest part of the Eemian, while at the same time in Schleswig-Holstein and Denmark a transgressive phase was followed by a regression. Within the Baltic, coldwater brackish conditions existed initially but warmer marine conditions with high salinities followed quickly. These early brackish conditions suggest that the Baltic was open to marine influence from at least the start of the Eemian. The abnormally saline phase started during zones E2a to E3a, at a nominal age of $132 \mathrm{kyr}$ $\mathrm{BP}$, and persisted until the end of E4b at c. $130 \mathrm{kyr}$ BP. During this time the Baltic was more marine than at 
Table 5. Summary of observational evidence for Eemian to Middle Weichselian sea levels in Svalbard.

\begin{tabular}{|c|c|c|c|c|c|c|}
\hline Region & $\begin{array}{l}\text { Approximate } \\
\text { coordinates }\end{array}$ & Evidence & Pollen zone & $\begin{array}{l}\text { Nominal } \\
\text { age } \\
\text { (kyr BP) }\end{array}$ & $\begin{array}{l}\text { Elevation } \\
\text { (m a.s.l.) }\end{array}$ & Reference \\
\hline Hopen & $76.5^{\circ} \mathrm{N} 25^{\circ} \mathrm{E}$ & $\begin{array}{l}\text { Pre-LGM marine } \\
\text { limit }\end{array}$ & Early Eemian? & 134 & 109 & Zale \& Brydsten (1993) \\
\hline Svenskøya & $78.7^{\circ} \mathrm{N} 26.5^{\circ} \mathrm{E}$ & $\begin{array}{l}\text { Pre-LGM marine } \\
\text { limit }\end{array}$ & Early Eemian? & 132.5 & 120 & Salvigsen (1981) \\
\hline Linnédalen & $78.1^{\circ} \mathrm{N} 13.8^{\circ} \mathrm{E}$ & Marine limit & $\begin{array}{l}\text { Post-MIS-4 glacial } \\
\text { maximum }\end{array}$ & 60 & 87 & Mangerud \& Svendsen (1992) \\
\hline \multirow[t]{3}{*}{ Brøggerhalvøya } & $78.9^{\circ} \mathrm{N} 11.3^{\circ} \mathrm{E}$ & Marine limit & Early Eemian & 134 & 80 & Forman \& Miller (1984) \\
\hline & & $\begin{array}{l}\text { Warm-water marine } \\
\text { sequence }\end{array}$ & Eemian & 130 & $>25$ & Miller et al. (1989) \\
\hline & & $\begin{array}{l}\text { Cooler marine } \\
\text { sequence }\end{array}$ & $5 \mathrm{a}$ & 85 & $? 25$ & Miller et al. (1989) \\
\hline \multirow[t]{3}{*}{$\begin{array}{l}\text { Prins Karls } \\
\text { Forland }\end{array}$} & $78.4^{\circ} \mathrm{N} 11.7^{\circ} \mathrm{E}$ & $\begin{array}{l}\text { Pre-LGM marine } \\
\text { limit }\end{array}$ & Early Eemian & 134 & 65 & Andersson et al. (1999) \\
\hline & & $\begin{array}{l}\text { Warm water marine } \\
\text { sequence }\end{array}$ & Eemian & 130 & $>10$ & Bergsten et al. (1998) \\
\hline & & $\begin{array}{l}\text { Cooler marine } \\
\text { sequence }\end{array}$ & $5 \mathrm{a}$ & 85 & $>10$ & Bergsten et al. (1998) \\
\hline \multirow[t]{3}{*}{ Kap Ekholm } & $78.6^{\circ} \mathrm{N} 16.7^{\circ} \mathrm{E}$ & $\begin{array}{l}\text { Warm water marine } \\
\text { sediments }\end{array}$ & Eemian & 130 & $? 20-25$ & Mangerud \& Svendsen (1992) \\
\hline & & Cooler water marine & Late Eemian & $125-120$ & $>15$ & Mangerud \& Svendsen (1992) \\
\hline & & Cooler water marine & $5 \mathrm{c}$ & 110 & $>25-30$ & Mangerud \& Svendsen (1992) \\
\hline \multirow[t]{2}{*}{ Bellsund } & $77.6^{\circ} \mathrm{N} 14.4^{\circ} \mathrm{E}$ & $\begin{array}{l}\text { Interstadial } \\
\text { sediments }\end{array}$ & $5 c$ & $110-105$ & $30-35$ & Landvik et al. (1992) \\
\hline & & & $5 \mathrm{a}$ & 85 & $\sim 0$ & Landvik et al. (1992) \\
\hline
\end{tabular}

any time during the Holocene and relative levels systematically increased from west to east. The late Eemian Baltic is characterized by a return to brackish conditions.

In the inversion of the sea-level data below, evidence from Svalbard summarized in Table 5 has been included, although this, as well as the comparison with the model predictions, will be discussed separately.

\section{First iteration results}

Figure 4 illustrates predictions for sea-level change, expressed relative to the present-day level, for some of the localities summarized in Tables 3 and 4, for the nominal ice history with different $\beta$ scaling parameters and earth rheology discussed above. Predicted marine limits are based on the nominal ice retreat history, and because sea-level change at this time is rapid within the areas of former glaciation their elevations are likely to be overestimated if localized ice remains after the general retreat.

\section{The Russian sector}

Taymyr Peninsula and October Revolution Island. - The highest reported level of the marine Boreal sea level on the Taymyr Peninsula occurs at Goltsovaya River north of the Byrranga Mountains (Table 3) and Fig. 4A illustrates the predicted values for this locality using three different $\beta$ values. This area, according to the model, is ice-free at $c .134 \mathrm{kyr} \mathrm{BP}$ and for $\beta=1$ the highest marine limits that could be anticipated here are c. $170 \mathrm{~m}$. The predicted rate of sea-level fall is rapid throughout the Last Interglacial interval and only small changes in this time of deglaciation modify significantly the predicted elevation of the marine limit. At the onset of the Boreal Eemian the predicted sea level for $\beta=1$ is $c .130 \mathrm{~m}$ and falling and a value of $\beta>1$ is appropriate. At Chelyuskin the predicted Eemian sea levels with $\beta=1$ fall from $c .130 \mathrm{~m}$ at the onset of the warm period to $c .75 \mathrm{~m}$ at the end of the boreal interval and for $\beta=0.8$ this range is from c. $100 \mathrm{~m}$ to $60 \mathrm{~m}$ (Fig. 4B) and when compared with the observational estimate this suggests that $\beta>0.9$. The model predictions for the Early Weichselian interval indicate that towards the end of the glaciation levels remained nearly constant at an elevation equal to the observed values if $\beta \approx 0.8$. For October Revolution Island the predictions for the early Eemian are consistent with the observed value if $\beta \approx 1$, while the comparison for the Early Weichselian suggests $\beta \approx 0.8$ (Fig. 4C).

The comparison of the predictions with the limited observational data from the other Taymyr Peninsula sites lead to the inferences summarized in Table 7. At Taymyr Lake for the Early Weichselian the predicted level with $\beta=1$ lies below the observed level if a deglaciation age of $90 \mathrm{kyr} \mathrm{BP}$ is assumed, but the rate of sea-level fall at this time is rapid and only a slightly earlier (c. $5 \mathrm{kyr}$ ) retreat of the ice margin than assumed results in the limit of $c$. $90-100 \mathrm{~m}$ a.s.l. reported by 
Möller et al. (1999). In the southern Taymyr, the model predictions for the two Agapa localities yield comparable predictions with a rapid fall throughout the Eemian. Only the predictions for the Nizhnyaya locality are shown in Fig. 4D and the results are consistent with the observation of falling levels at $>117 \mathrm{~m}$ a.s.l. if $\beta \geq 0.8$. For the lower Agapa locality the prediction for Late Eemian sea levels with $\beta=1.0$ is consistent with the cold-water marine fauna sediments at $50-60 \mathrm{~m}$ a.s.1. If these cold-water sediments are of Weichselian origin, as suggested by Gudina (1966), then this would imply an Early Weichselian age of c. $90 \mathrm{kyr} \mathrm{BP}$ for $\beta=1.0$. At all localities, the predictions for the Eemian are of a rapidly falling level throughout the Eemian interval. Marine limits, therefore, can be expected to occur at $50 \mathrm{~m}$ or more above marine sediments from the warm boreal phase unless the end of the local glaciation occurred later and coincided with the onset of this latter phase. Elevations of the marine limits in this region have not been reported and only at Agapa have cold-water marine sediments of earliest Eemian age been identified.

The predicted spatial variability of sea level across the Taymyr region is substantial and this is illustrated in Fig. 5A for a profile orthogonal to the Khatanga valley from where the Lower Taymyr River reaches the Kara Sea to the Khara-Tas Ridge south of the Khatanga River. At $132 \mathrm{kyr} \mathrm{BP}$ and with $\beta=1$ the
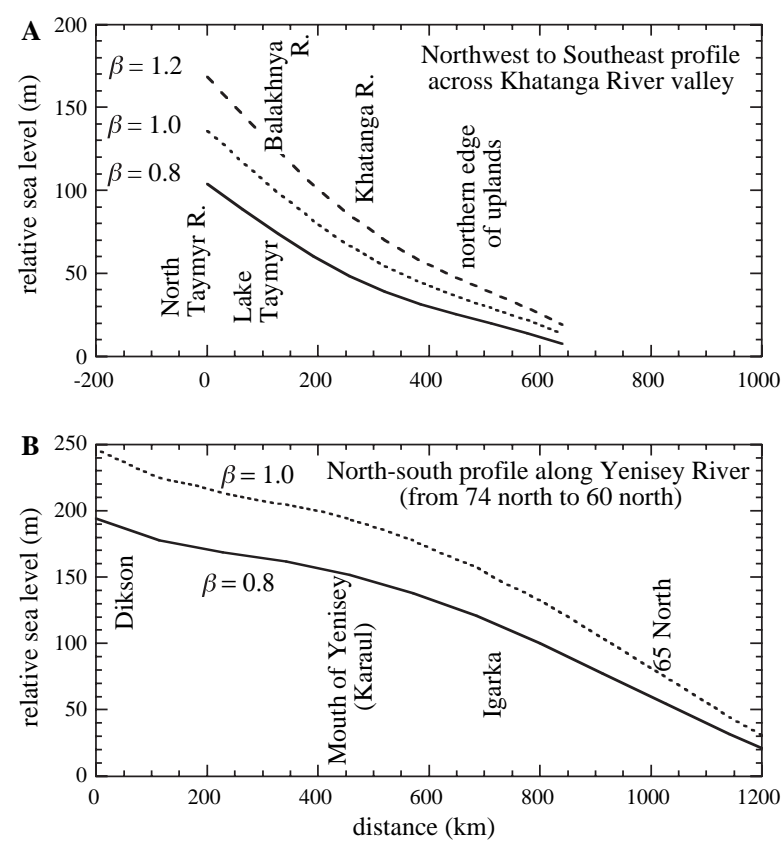

Fig. 5. Predicted spatial gradients of sea-level change at $132 \mathrm{kyr}$ BP corresponding to the nominal time of the boreal period in arctic Russia. A. A northwest-southeast profile from the Kara Sea to the uplands south of the Khatanga River and approximately normal to the Khatanga River Valley axis. B. A north-south profile along the Yenisey Bay and River southwards from Dikson for two different $\beta$ values. predicted elevations range from $c .130 \mathrm{~m}$ a.s.l. at the coast to near present sea level at the southern end of the transect. Similar gradients are predicted along profiles approximately parallel to the Khatanga River valley from the Laptev Sea to the Putorana uplands. These results illustrate two points: (i) for any observation of the elevation of the Interglacial shorelines to be useful for constraining the ice model, relatively accurate locations for the observations are required and (ii) observations of spatial variability across the region potentially provide a strong constraint on the regional ice model.

Siberian Plain: Yenisey, Gydan, Yamal. - For Yenisey Bay the predictions are similar to those for Agapa and the observations provide only lower limits. For the more southern Yenisey River locality all predictions lie well above the reported height of the lower elevation limit of the marine boreal transgression and, likewise, this information does not place a strong constraint on the model unless the depth and precise timing of deposition can be established. The predictions for the two Yenisey River sites do indicate that a large northsouth gradient in sea level can be expected at all epochs, as illustrated in Fig. 5B for a profile from the Kara Sea north of Dikson to $c .65^{\circ} \mathrm{N}$, where the minimum topographic elevation approaches $100 \mathrm{~m}$ and which corresponds approximately to the predicted maximum southern limit of the boreal inundation. Observations of this limit and of the north-south gradient would provide strong model constraints.

The Taz observations are also limiting values during the boreal period and do not provide strong constraints other than that for the northern locality for which $\beta>$ 0.6 (Fig. 4E). Here, also, any observations of the southern limit and the gradient of the marine inundation would provide significant constraints on the icesheet model. The Gydan-Yamal Peninsula predictions with $\beta \geq 0.8$ are consistent with the observations of cold-water marine sediments deposited during Early Weichselian time whether this occurred during MIS-5c or $5 \mathrm{a}$.

Pechora Lowlands to Arkhangelsk. - The information from the Sula River is from marine boreal fauna with a lower-limiting elevation of $40-50 \mathrm{~m}$ a.s.l. and only values of $\beta<0.5$ are excluded. The highest predicted marine limits range from $c .120 \mathrm{~m}$ for $\beta=0.6$ to c. $250 \mathrm{~m}$ a.s.l. for $\beta=1$ and the immediate post-Saalian inundation, preceding the boreal period, is predicted to have been extensive. The predictions for Tarkhanov and Tobuyev on the Kanin Peninsula, as well as for the North Kanin coastal site, are similar, and the comparison with the observed elevations of shoreface sediments at the first two localities indicates $\beta>0.8$ if the tidal sediments correspond to the Boreal period. The third observation (Larsen et al. 2006) of Early Weichselian tidal sediments below the present sea level is 
inconsistent with any model predictions unless there was an absence of ice for the preceding (Late Saalian) period. One possible interpretation would be that these sediments are younger, either from the end of the Eemian at c. $115 \mathrm{kyr}$ BP or of Early Weichselian age at c. $80 \mathrm{kyr}$ BP (Fig. 4F).

The predicted early Middle Weichselian sea levels for Cape Tolstik lie below the observed values of $15-25 \mathrm{~m}$ unless $\beta>1.2$ for the preceding MIS-4 glaciation. Both the Pyoza River observation of early Eemian foreshore sediments above $63 \mathrm{~m}$ elevation and the marine limit near $100 \mathrm{~m}$ a.s.l. indicate $\beta \geq 0.8$, which is consistent with the Kanin Peninsula inference. However, as for localities such as Kanin Peninsula the prediction is for a falling sea level from the time the region first became ice-free to the end of the Eemian. For Pasva in the south of the Dvina basin the predicted curve for $\beta=1$ lies below the observed levels (Fig. 4G) and this suggests that ice thickness over the Arkhangelsk area needs to be increased by $\beta \geq 1$.2. Only for low $\beta$ values do the predictions resemble a 'Litorina' signal that is characteristic for sites near to but within the former Late Weichselian ice margins of Scandinavia, where the ice is comparatively thin (Eronen et al. 2001; Vorren et al. 1988). But when the transgressive phase is produced the maximum elevation of the transgressions is also substantially reduced and the rebound models do not produce high-elevation transgressive phases.

\section{The European sector including Karelia and Kola Peninsula}

Finland Gulf and Karelia. - The observation from the continental divide between the Gulf of Finland and the White Sea is one of warm-water fauna that crossed from north to south during the pollen zone E2b-E4b or at about $132-130 \mathrm{kyr}$ BP. If this overflow ended towards the end of this interval, then based on the predicted gradients for this site at the onset of the warm-water flow the levels must have been $c .35 \mathrm{~m}$ above the sill height of $c .105 \mathrm{~m}$ a.s.l. Thus, the model predictions at Povenets are consistent with this observation if $\beta>1-1.1$ (Fig. $4 \mathrm{H}$ ). For the continental divide to have been submerged at all, the Late Saalian ice thickness over Finland and Karelia had to be substantially greater than at any time during the LGM and any plausible postglacial sea-level curve is characterized by a monotonic quasi-exponential fall in level throughout the interglacial period. Thus the observation of warm-water transport from north-to-south requires that this was preceded by a period of inundation of either cold arctic-marine water or of cold fresh water if an arctic ice dam persisted into the lateglacial period. The suggestion from the Ostrobothnia data that the early Eemian period was characterized by fresh water conditions while in Riga Bay and elsewhere in the western Baltic the early cold phase is associated with brackish water conditions, suggests that the earliest flow across the Karelia sill was primarily melt water from the residual ice sheets on the Kara-Barents shelves and that a northern ice barrier diverted meltwater southwards and across the continental divide until early Eemian time.

The predictions for the Petrozavodsk locality on Lake Onega are essentially identical to those for Povenets and indicate inundation of the site until about $126 \mathrm{kyr} \mathrm{BP}$ if $\beta=1-1.1$, as indicated by the Povenets result, with depths of at least $100 \mathrm{~m}$ during the E2 zone and $65 \mathrm{~m}$ during E4b. In the Neva Lowlands, all models considered are consistent with relatively deep water at the Mga site for the early Eemian interval, ranging from water depths at $132 \mathrm{kyr} \mathrm{BP}$ of $c .70 \mathrm{~m}$ for $\beta=1$ to $c .30 \mathrm{~m}$ for $\beta=0.6$.

Kola Peninsula. - The observations from the Kola Peninsula represent the upper limits of marine sediments of Boreal Eemian age and the sea surface must be at or above these elevations. Their locations are mainly from the east coast (Kola sites 2, 3, 4, 7, 8 ; Table 4), with additional data from the south coast (Kola sites 5,6) and from the interior (Kola site 1) of the peninsula. The predicted average elevation for the eight sites is a function of the assumed age of the sediments as well as of the scaling parameter, as illustrated in Fig. 6A, and if, for example, the age corresponds to the start of the pollen zone E5, then $\beta \approx 1.2$. There is, however, some regional trend in the comparisons of the individual observed and predicted values in that the predicted elevations (for $\beta=1.2$ and an assumed epoch of $129 \mathrm{kyr}$ BP) exceed the observed levels at the two south coast sites and are too low at the five east coast localities (Fig. 6B) and either the shorelines are not synchronous, the southern ones having formed about $1 \mathrm{kyr}$ after $129 \mathrm{kyr} \mathrm{BP}$ and the eastern ones about $2 \mathrm{kyr}$ before $129 \mathrm{kyr} \mathrm{BP}$, or there is a gradient in the scaling parameter with $\beta \approx 1$ to the south and $\beta \approx 1.3$ in the east. These results illustrate that data from different localities across the peninsula can contribute to a separation of some of the unknowns.

Ostrobothnia. - The predictions for the six Ostrobothnia sites discussed above are similar, producing high marine limits for the nominal time of ice retreat at $136 \mathrm{kyr}$ BP followed by a rapid postglacial sea-level fall. At these sites, the crustal rebound component dominates the eustatic change throughout the early Eemian period and the sea-level curve falls continuously throughout the interglacial. Signals such as the early transgressions characteristic of the post LateWeichselian (Litorina) period are not, therefore, predicted (Fig. 4I). The result for Evijärvi gives $\beta=0.8$ and is representative of the other localities (Table 6). Such a reduction in ice thickness is consistent with the inference from the Kola Peninsula data that the model 

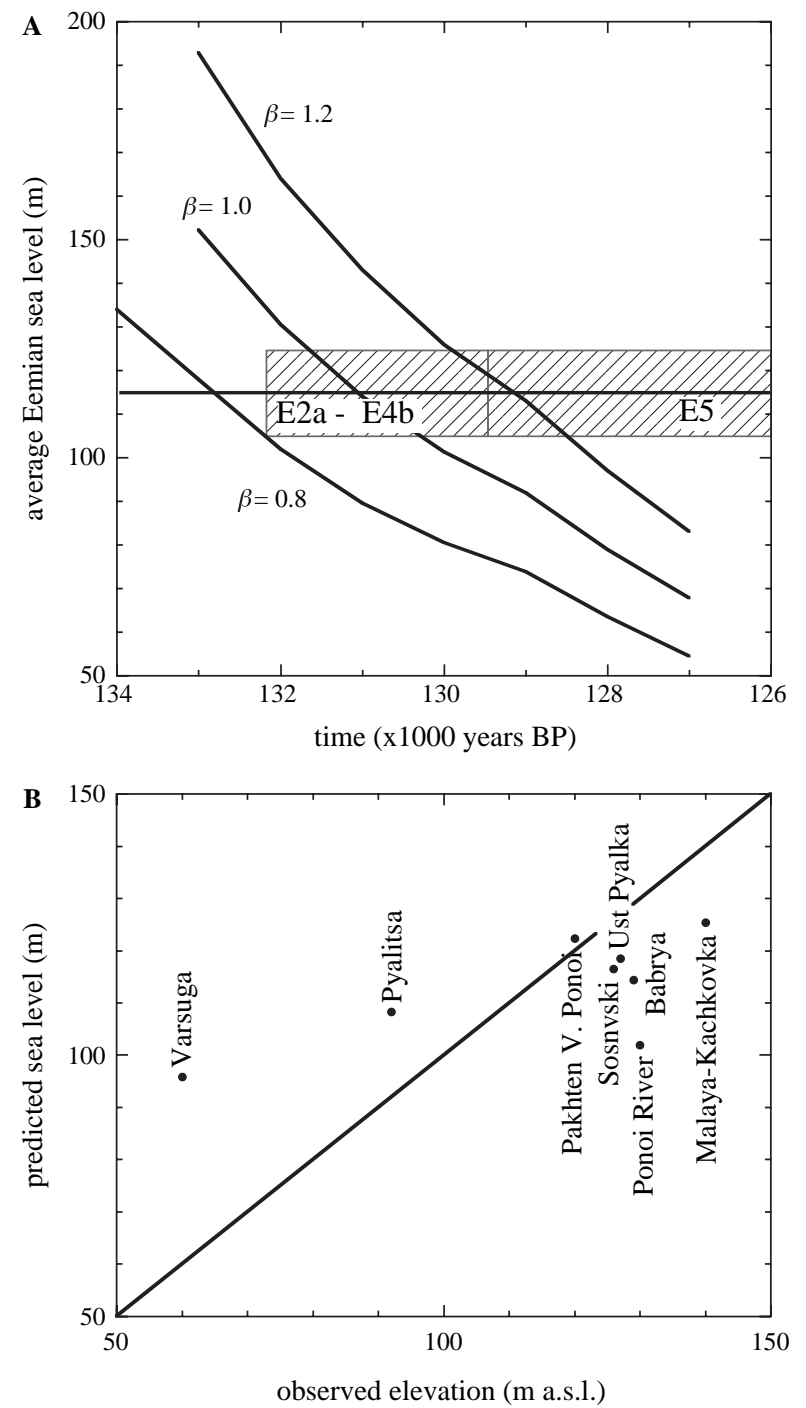

Fig. 6. Comparison of observed and predicted sea levels for the Kola Peninsula for the early phase of the Eemian. A. Predicted Eemian sea level, averaged over the eight shoreline locations in Table 5, as a function of assumed shoreline age $t_{\mathrm{s}}$ and uniform scaling parameter $\beta$. The shaded area corresponds to the $\beta-t_{\mathrm{s}}$ parameter space that is consistent with the observed data. If $t_{\mathrm{s}}$ is early Eemian then $\beta \approx 1.0$ and adoption of a late shoreline formation age implies an increase in ice thickness during the preceding glaciation. B. Predicted versus observed Eemian shoreline elevations for $\beta=0.9$ and $t_{\mathrm{s}}=129 \mathrm{kyr} \mathrm{BP}$

ice thickness needs to be reduced south of the Kola Peninsula.

Sweden and Norway. - At the central Sweden sites, the predictions based on the nominal ice model with $\beta=1$ mostly yield local sea levels that exceed the observed isolation or limiting values summarized in Table 4. At Bollnäs, for example, the prediction for the nominal unscaled model is of water depths of $c .30 \mathrm{~m}$ for the early part of the observational record with terrestrial conditions occurring only at the end of the warm interval (Fig. 4J). Thus a value of $\beta \approx 0.9$ appears to be consistent with the field evidence here, as well as at Dellen. The Boliden upper limit observation does not impose a useful constraint on the model because all models with $\beta \leq 1.2$ lead to the prediction that early Eemian sea levels lie below the limiting value of c. $204 \mathrm{~m}$. If the observation corresponds to an Early Weichselian event rather than to an Eemian level, then it also does not lead to a useful constraint on the ice models. At Stenberget, the predicted marine limit and subsequent Eemian levels lie below the observed upperlimit value for $\beta \leq 1.0$.

Fjøsanger lies near the ice margin in Late Saalian time and the actual prediction here is sensitive to the details of the melting history, as it is for the post LGM period (Lambeck et al. 1998b), and the model cannot claim to have an accurate ice retreat history here. Nevertheless, agreement for the early Eemian is broadly satisfactory for $\beta \approx 0.8-1.0$ (Fig. $4 \mathrm{~K}$ ), although the predicted rate of fall during the latter part of the Eemian is more rapid than inferred from the observational data. Experiments with a range of alternate retreat histories indicates that the Late Eemian observations can be attributed to earlier melting of a thicker ice sheet, but this would also lead to increased elevation of the marine limit.

Southern and western Baltic and North Seas. - For the Baltic coast from Latvia to Germany, the model with $\beta=1.0$ predicts well-elevated shorelines immediately after the ice retreat, such that in the Vistula estuary, for example, coastal areas below c. $100 \mathrm{~m}$ a.s.l. are inundated very early in the interglacial period. But by the time of onset of the warm phase the predicted levels have dropped to $c .50 \mathrm{~m}$ for $\beta=0.8$ or to $c .30 \mathrm{~m}$ for $\beta=0.6$ and when compared with the observational data this suggests that a reduction in $\beta$ is appropriate. Based on the digital topographic database used in the present reconstruction (see below), this predicts a marine warm early Eemian inundation $60-80 \mathrm{~km}$ inland in the Vistula valley if $\beta=0.8$, which is generally consistent with the field evidence.

Near the margin of the Late Saalian ice sheet the predicted sea levels vary rapidly with position, as is indicated in Fig. 7 at sites from near Amsterdam, to the western end of the Friesian Islands, Schleswig-Holstein, Ristinge klint (Lille Bælt, southern Denmark) and Skåne (Stenberget). At Amsterdam or the western Friesian Islands the predicted sea-level function is one of a constantly rising level throughout the late glacial and early Eemian phase with a small amplitude (c. $2 \mathrm{~m})$ highstand developing in the latter part of the interglacial. For the Schleswig-Holstein or Ristinge areas, however, the predicted rebound has evolved to falling sea level during the Lateglacial period, reaching a relative minimum in the early Eemian and rising to a small highstand at $c .129 \mathrm{kyr}$ before again falling until the end of the interglacial. For Schleswig-Holstein the predicted maximum water depth is consistent with 
Table 6. Predicted elevation of isolation for the Ostrobothnia sites based on the nominal ice model with three different scaling factors $\beta$. Agreement between the observed and predicted values is satisfactory only if $\beta \approx 0.8$.

\begin{tabular}{|c|c|c|c|c|c|}
\hline \multirow[t]{2}{*}{ Site } & \multirow{2}{*}{$\begin{array}{l}\text { Observed isolation } \\
\text { ( } \mathrm{m} \text { a.s.l.) }\end{array}$} & \multirow{2}{*}{$\begin{array}{l}\text { Adopted time of } \\
\text { isolation (kyr BP) }\end{array}$} & \multicolumn{3}{|c|}{ Predicted elevation of isolation ( $\mathrm{m}$ a.s.l.) } \\
\hline & & & $\beta=1.0$ & $\beta=0.8$ & $\beta=0.6$ \\
\hline Evijärvi & 61 & 131.0 & 86 & 66 & 50 \\
\hline Vesiperä & 103 & 132.2 & 140 & 106 & 71 \\
\hline Ollala & 116 & 132.4 & 158 & 118 & 80 \\
\hline Kärsämäki & 106 & 132.1 & 150 & 106 & 71 \\
\hline Norinkylä & 112 & 132.2 & 155 & 117 & 80 \\
\hline Peräseinäjoki & 89 & 131.4 & 130 & 97 & 66 \\
\hline
\end{tabular}

the observed values only if $\beta<0.6$ and at Ristinge the prediction is consistent with the observed trends of a sea-level rise from $c .132 .5$ to $129 \mathrm{kyr}$ BP followed by a fall until c. $120 \mathrm{kyr}$ BP.

The comparison of observations with predictions for The Netherlands and North Sea localities of Zagwijn (1996) is illustrated in Fig. 4L. In this case the observations have been corrected for tectonic subsidence as well as for the differential isostatic corrections between the specific sites and the chosen reference site, Amsterdam. These latter corrections are ice-model dependent but relatively small, $c . \pm 3 \mathrm{~m}$ in the $\beta$ range of $0.6-1.0$. The predicted sea levels likewise are not strongly dependent on the choice of $\beta$ in this range and the comparison illustrated here is valid for at least this range of ice thickness estimates. An important feature of the comparison is that the 'observed' sea-level function, reduced to the Amsterdam site, now leads the predicted value by $c .1 .5-2 \mathrm{kyr}$; that once corrected for the tectonic subsidence and the differential isostasy, the local sea level reaches a near-constant value earlier than assumed. The appropriate epoch for the end of the pollen zone E4b is therefore 128-127.5 kyr BP; the onset of E1 also occurred later by $1.5-2 \mathrm{kyr}$.

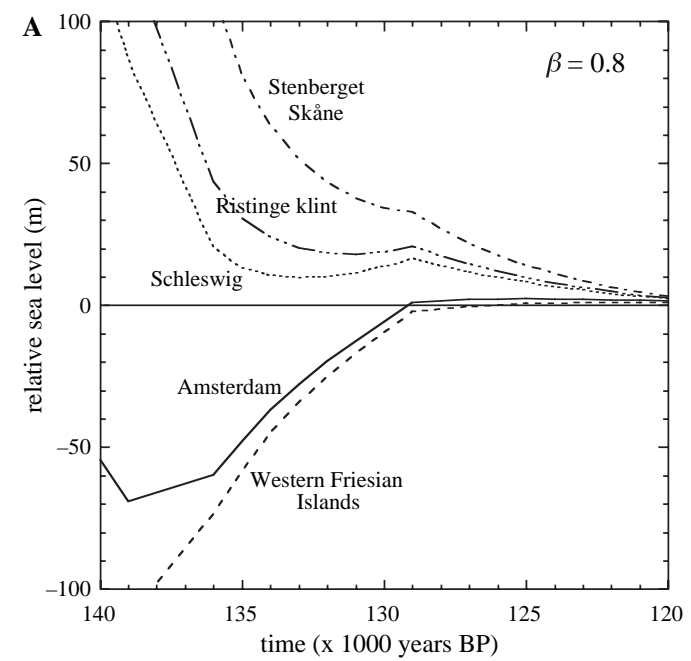

\section{Summary of the ice-scaling parameters}

Table 7 summarizes the ice-thickness scaling parameters inferred from the comparison of the observations with the above first-approximation model predictions. Across the Taymyr Peninsula $\beta>1.0-1.1$ for the Late Saalian glaciation and the maximum ice thickness over the Taymyr Lake and northern coastal zone areas during the Late Saalian will therefore have equalled or exceeded $2000-2200 \mathrm{~m}$. These estimates are based on the assumption that the boreal period across the Taymyr is in phase with the pollen chronology established further west, and if some lag did occur, then for sites well within the former ice margins predicted elevations would be lower and the inferred ice sheet would be proportionally thicker. For example, if the onset of the boreal environment occurred 1000 years later in Taymyr than in the Baltic, then the predicted Eemian sea levels at Lake Taymyr would be reduced by c. $10-15 \mathrm{~m}$ (e.g. Fig. 4A) and the inferred scaling parameter would be increased by about $10 \%$. This is largely within the uncertainty of the scaling parameters. For the Early Weichselian interval the model predictions with $\beta \approx 1$ are broadly consistent with the observations as well as being internally consistent with

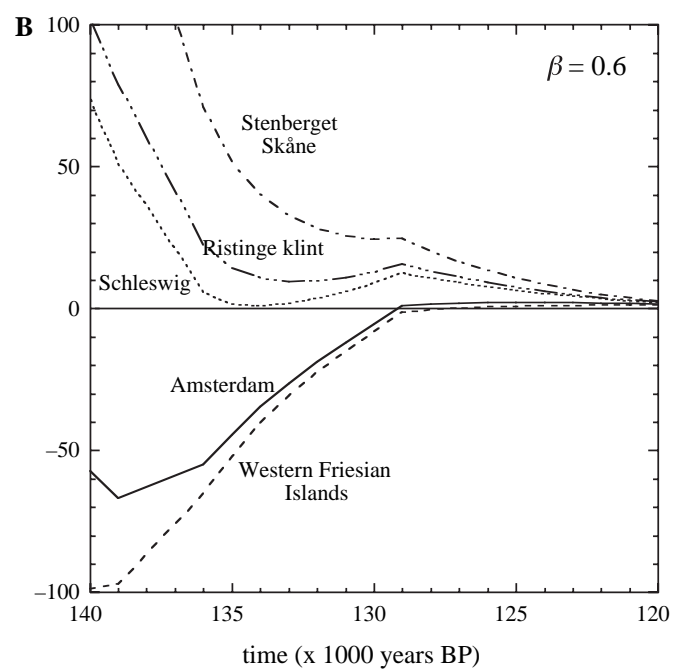

Fig. 7. Predicted sea levels from the North Sea (Amsterdam) to southern Sweden (Skåne) for the nominal ice model scaled with (A) $\beta=0.8$ and (B) $\beta=0.6$. 
Table 7. Summary of the regional ice-height scaling parameters inferred from the comparison of the observed sea levels with the model predictions.

\begin{tabular}{|c|c|c|c|c|}
\hline Region & Locality & Late Saalian & Early Weichselian & Middle Weichselian \\
\hline \multirow[t]{7}{*}{ Taymyr } & Goltsovaya River & 1.1 & & \\
\hline & Lake Taymyr & $1-1.2$ & 1.2 & \\
\hline & Bolshaya & $>1$ & & \\
\hline & Luktakh River & $>0.9$ & & \\
\hline & Chelyushkin & $>0.8$ & 0.7 & \\
\hline & Lower Agapa River & $>1$ & & \\
\hline & Nizhnyaya Agapa & $>0.8$ & & \\
\hline Severnaya Zemla & October Revolution Island & & 1.2 & 0.8 \\
\hline \multirow{2}{*}{ Western Siberia } & Taz Peninsula & $>0.6$ & & \\
\hline & Gydan-Yamal & & $>0.8$ & \\
\hline Pechora & Sula River & $>0.5$ & & \\
\hline \multirow[t]{4}{*}{ Arkhangelsk region } & Kanin, Tarkhanov and Tobuyev & $>0.8$ & & \\
\hline & Cape Tolstik & & & 1.2 \\
\hline & Pyoza River & $>0.8$ & & \\
\hline & Vaga River, Pasva & 1.2 & & \\
\hline Karelia & Continental Divide & $>1.0-1.1$ & & \\
\hline \multirow[t]{3}{*}{ Kola Peninsula } & South coast & 1.0 & & \\
\hline & East coast & $>1.3$ & & \\
\hline & Average & 1.2 & & \\
\hline Finland & Ostrobothnia & 0.8 & & \\
\hline \multirow[t]{3}{*}{ Sweden } & Bolnäs, Delen & $0.8-1.0$ & & \\
\hline & Boliden & $1.2>1$ & & \\
\hline & Stenberget & & & \\
\hline Norway & Fjøsanger & 0.8 & & \\
\hline \multirow[t]{2}{*}{ Southern Baltic to North Sea } & Vistula & $0.6-0.8$ & & \\
\hline & Schleswig Holstein & 0.6 & & \\
\hline \multirow[t]{7}{*}{ Svalbard } & Hopen & 1.0 & & \\
\hline & Kong Karls Land & 1.0 & & \\
\hline & Brøggerhalvøya & $>1$ & $=1$ & \\
\hline & Prins Karls Forland & $>0.8$ & $>0.8$ & \\
\hline & Kap Ekholm & $=1$ & & \\
\hline & Bellsund & & $=1$ & \\
\hline & Linnédalen & & $=1.2 *$ & \\
\hline
\end{tabular}

*Value inferred if the marine limit is of Early Weichselian age.

the adopted ice retreat history and the region's maximum ice thickness estimates for the Early Weichselian stadials (MIS-5d and MIS-5b) are c. 1000-1100 m.

In West Siberia the observational constraints place only lower limits on the scaling parameter of $\beta_{\min } \approx$ 0.8 , but these are consistent with the estimates from Agapa in southwestern Taymyr. Likewise, west of the Urals the estimates provide only minimum limits, the least of which is for the Sula River with $\beta_{\min } \approx 0.6$, while the data from the Pyoza River and Kanin Peninsula yield $\beta_{\min } \approx 0.8$. The southern Dvina basin result (Vaga River), however, indicates a need to scale up the nominal ice thickness $(\beta \approx 1.2)$, and this result may place an upper limit on the ice height for the region as a whole because the locality lies outside the post-Late Saalian ice margins and there has been no subsequent glaciotectonic deformation of the Eemian deposits. We have adopted this upper limit as representative of the region, which means that the marine deposits at the other localities formed either in relatively deep water, of $c .40 \mathrm{~m}$ in the case of the Sula River deposits or c. $30 \mathrm{~m}$ in the case of the Pyoza
River, or that they have been vertically displaced by subsequent Weichselian glaciations.

At localities such as Agapa, Sula and Pyoza River, the Boreal Eemian sediments are interpreted as having been deposited during a period of sea-level rise followed by a regressive phase later in the interglacial (Gudina et al. 1968; Mangerud et al. 1999; Grøsfjeld et al. 2006). The model predictions, with the exception of sites near the former ice margin, however, do not support a transgressive phase at any time during this phase. Only for the Dvina Basin site, where the locality became ice-free early in the Late Saalian deglaciation phase, do the model predictions point to a possible transgressive phase during the early Eemian interval. Elsewhere the predicted Eemian sea level is dominated throughout by the crustal rebound and no range of scaling parameters yields both high levels and a transgressive phase during the Boreal period. This is illustrated in Fig. 8 for the Sula River, where the transgressive phase occurs only if there is a considerable reduction in ice thickness over the Pechora lowlands: only if $\beta<0.3$ does the model yield relative 


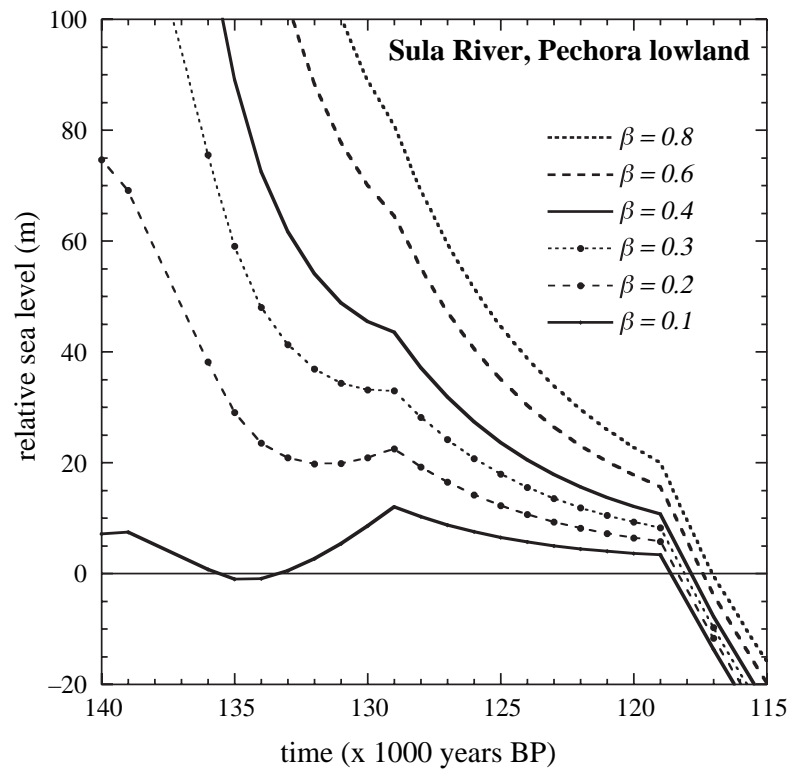

Fig. 8. Predicted sea level at Sula River with different scaling parameters $\beta$. For the larger values the rebound dominates the eustatic change and sea levels fall continuously throughout the Last Interglacial. For the smaller values, sea levels rise during the early Eemian interval.

highstands in the early Eemian interval, but in this case the highest Eemian levels do not attain the elevations recorded both in the Sula River area and elsewhere in the Dvina-Arkhangelsk-Mezen area. This apparent discrepancy between model and field observations will be investigated in future work.

The inference for thick ice east of the Urals is also consistent with estimates from the Karelia continental watershed and the Kola Peninsula, with both locations pointing to a need to increase the nominal ice thickness. For Finland and Sweden, in contrast, $\beta \approx 0.8$, and ice models in which the Scandinavian and eastern Russian ice formed distinct domes during the Late Saalian are excluded. Instead it points to some of the thickest Late Saalian ice having been centred over the Arkhangelsk-Karelia region. In the western Baltic area a greater reduction in ice thickness appears necessary with $\beta \approx 0.6$ over Denmark and the North Sea such that the maximum ice thickness over Denmark would not have exceeded c. $700 \mathrm{~m}$ during Late Saalian time. Such a trend for relatively thin ice over this region is consistent with inversion results for the post-LGM sea-level data.

\section{Higher iteration ice models}

In so far as the limited data permit, in the few regions where it has been possible to estimate the ice-scaling parameters for different epochs, the model-observation comparisons indicate that similar scaling is appropriate from Late Saalian to Middle Weichselian time. Thus the preliminary ice-model assumption of similar basal conditions for the successive glaciations provides a useful first approximation description of relative ice thickness. The variability of the scaling parameter $\beta(\varphi)$ with position $\varphi$ across the region has been estimated by fitting a low-order polynomial surface through the individual estimates (Table 7) with the condition that minimum change occurs in areas where there is no information. This function is then used to scale the preliminary ice sheet from MIS-6 through to MIS-4 to yield the second approximation to the ice heights. The average effect of this scaling is to increase ice volumes by c. $10 \%$ and globally this is compensated for by modifying the far-field ice sheets such that the global ice volume remains consistent with the observed constraints.

In the subsequent iterations the Eemian time scale of the observational evidence is also modified for each revision of the isostatic corrections at the individual sites making up the Netherlands sea-level curve (Zagwijn 1996) sites and the last-iteration chronology is given in Table 1. Because the time series of the melting history is constrained by the global sea-level curve whose age control is established from the uranium-series chronology, the effect of the shift in the Eemian pollen chronology is to shift the time of the early Eemian observations to younger ages. Thus, in an environment of falling levels the predicted sea levels will be lower than for the nominal chronology, and to

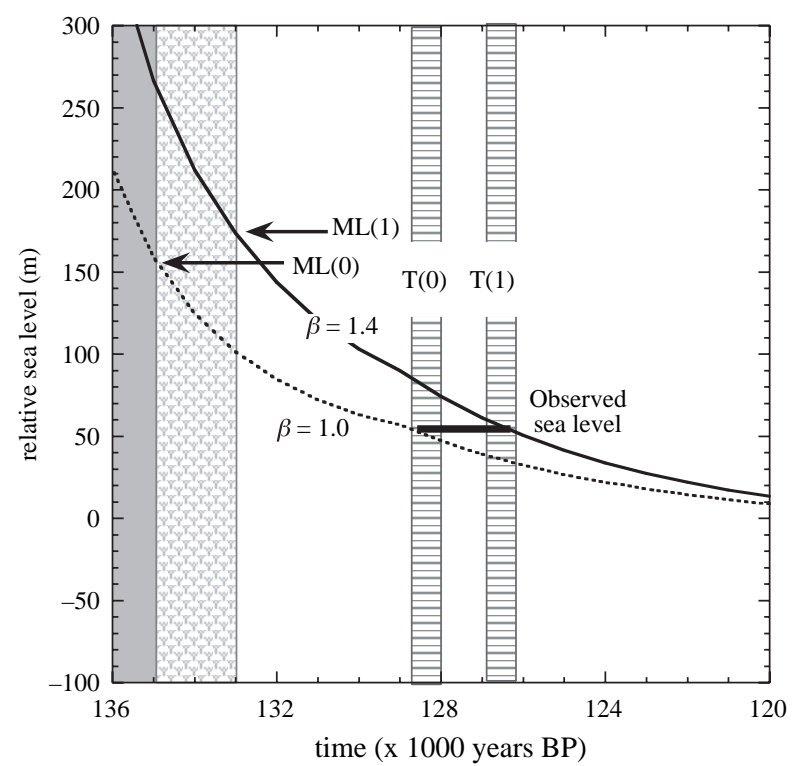

Fig. 9. Comparisons of sea-level predictions for Ostrobothnia with observations for different time scales for the latter data. The shading is the same as in Fig. 4. For the preliminary time scale, the observation occurs at $\mathrm{T}(0)$ and the predicted sea level function passes through the observed value for $\beta=1$. If the relative chronology of the observational data is delayed by $2 \mathrm{kyr}$ to $\mathrm{T}(1)$, the sea level prediction needs to be scaled upwards in order for it to agree with the observed elevation. The time shift of $2 \mathrm{kyr}$ results in an increase in the inferred ice thickness of $40 \%$. ML(0) and ML(1) refer to the marine limits for the two relative chronologies. 
match the observed values the Saalian ice model will need to be scaled upwards. An example for one of the Ostrobothnia sites is illustrated in Fig. 9. For the preliminary time scale the instant of observation is $\mathrm{T}(0)$, the predicted sea level agrees with the observed value for $\beta=1.0$, and the marine limit is at $\operatorname{ML}(0)$. When the relative chronology is delayed by $2 \mathrm{kyr}, \mathrm{T}(1)$, then the prediction needs to be increased by c. $40 \%$ in order to match the observed value. If the local ice retreat history is tied to the pollen chronology then this will also occur later, but the marine limit ML(1) will occur at a higher elevation because of the ice thickness increase. Thus one of the principal features of the higher iteration models will be that the Late Saalian ice thickness is increased.

Several iterations have been made until the solution has converged. Figure 10 illustrates comparisons
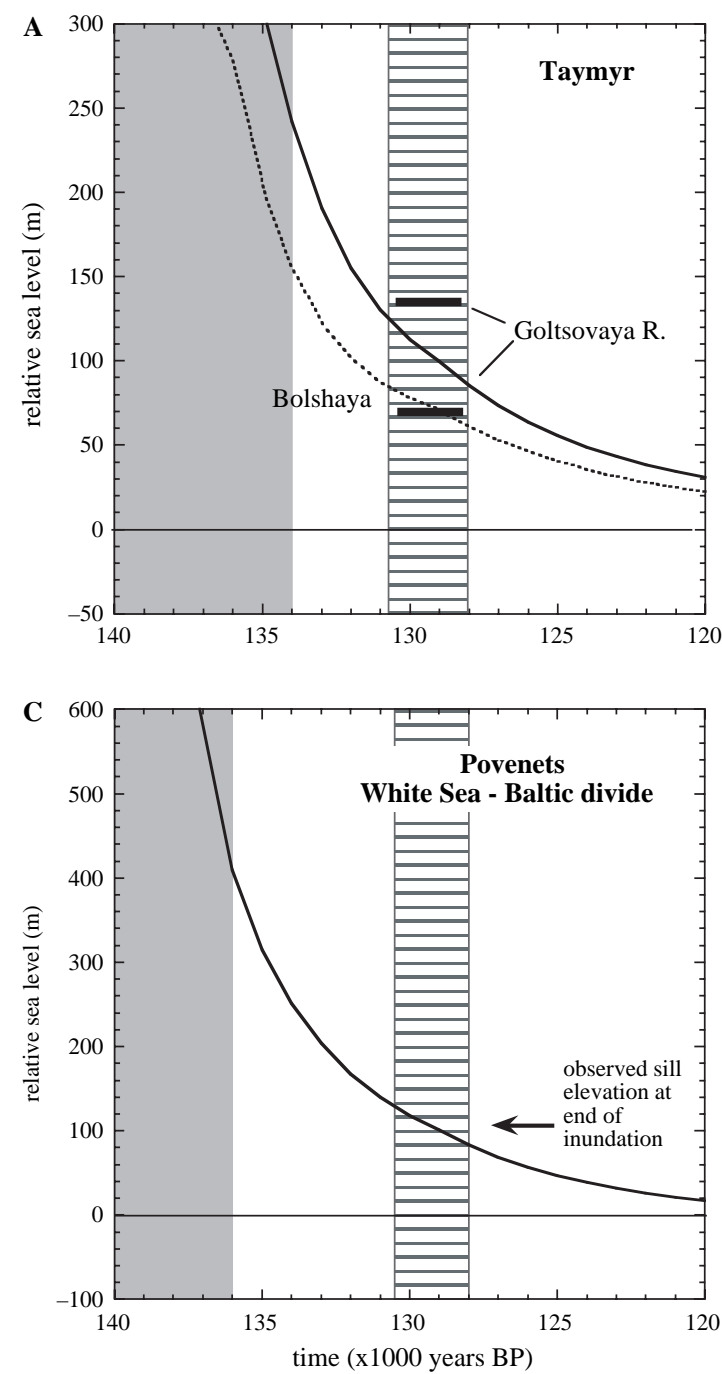

between observed and predicted sea levels at four sites. These results are similar to the earlier iteration solutions, the principal difference being the trade-off that occurs between the time scale of the pollen chronology and the Saalian ice thickness: shifting the onset of the Eemian to a younger age results in an increase in the inferred ice thickness. Comparisons for two Taymyr sites are shown in Fig. 10A. At Goltsovaya, and to a lesser degree at the Lake Taymyr sites, the predictions are underestimated, but at Bolshaya, as well as the other Taymyr localities, agreement is good. For all localities, high marine limits are predicted. For the Vaga River locality (Fig. 10B), the prediction is one of a rising sea level during the immediate postglacial phase into the early Eemian with a transgression occurring towards the end of this period. Of the sites considered here, this is the only Russian
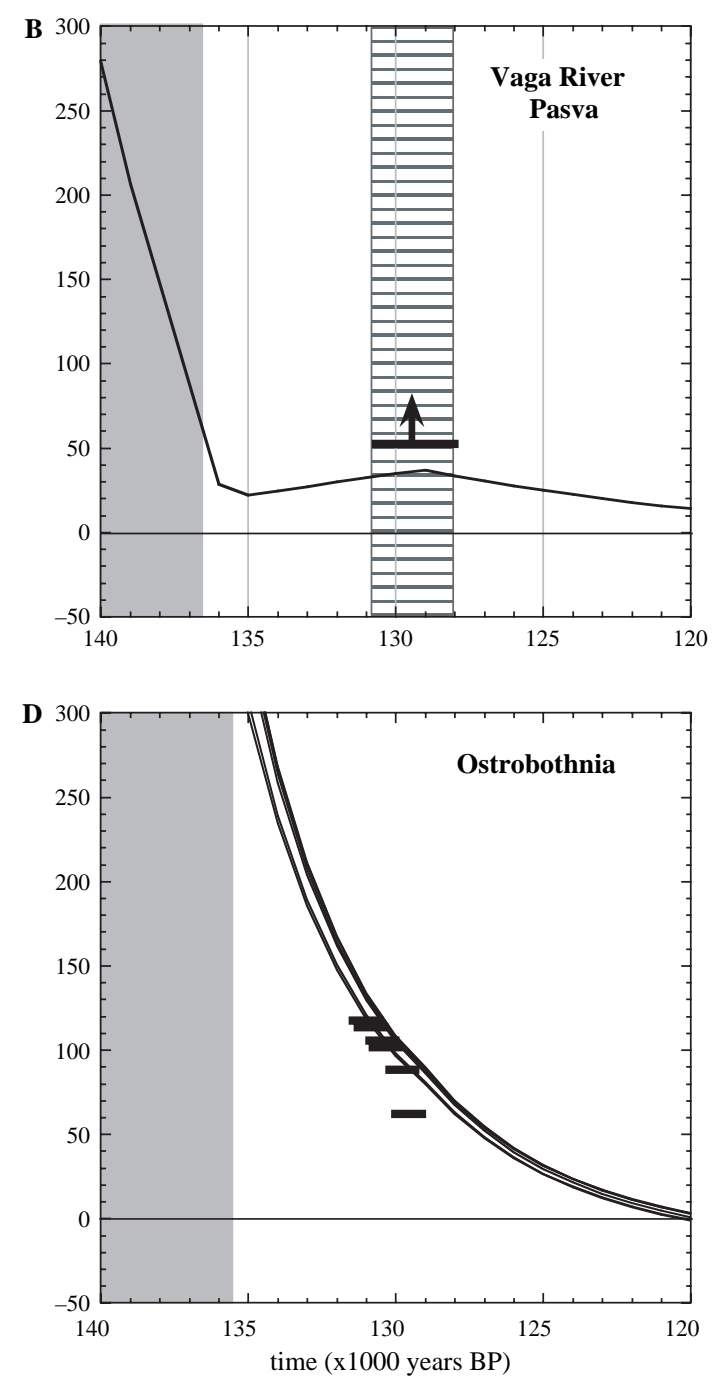

Fig. 10. Same as Fig. 4, but with predictions based on the revised ice model and with the Eemian observations referred to the revised time scale. A. Two representative results for the Taymyr Peninsula. B. Pasva on the Vaga River. C. The Karelia watershed near Lake Onega. D. The six Ostrobothnia sites. Of the latter, the model predictions fall into two groups with the lower limits corresponding to the Norinkylä and Peräseinäjoki sites. 


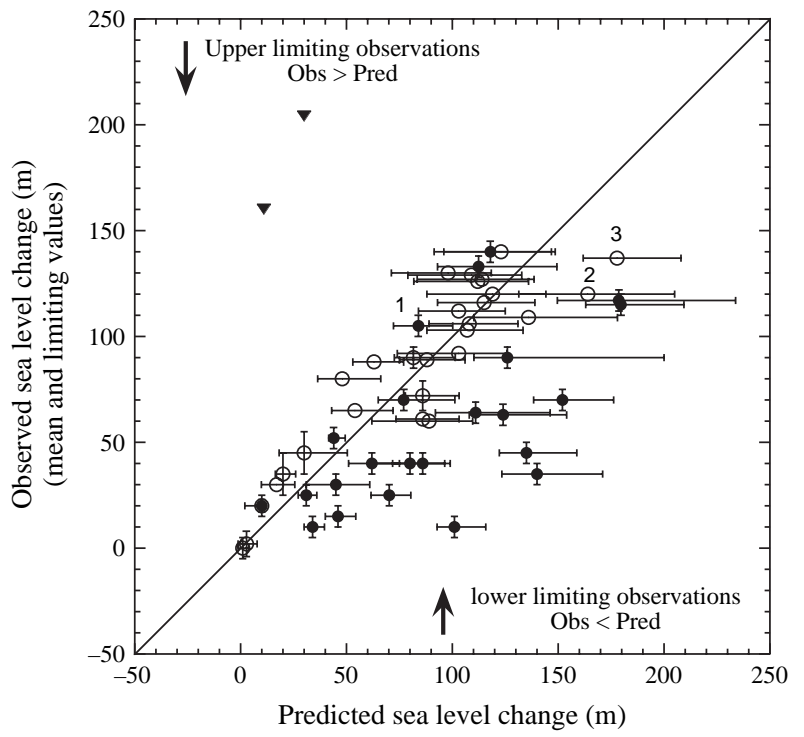

Fig. 11. Comparison of early to late Eemian observed and predicted sea levels with the latter based on the iterated model and the observations reduced to the absolute time scale. Observational accuracies and predicted sea-level accuracies are discussed in the text. Lower limiting observations (solid circles) should lie below the 1:1 line and upper limiting observations (inverted solid triangles) should lie above this line. The estimates of mean sea level (open circles) should, within accuracy estimates, fall on this line. Point 1 (solid circle) denotes the result for the Karelia watershed, while points 2 and 3 (open circles) refer to two observations of marine limits on Kong Karls Land and Hopen.

site for which such a transgressive phase is predicted and for which the marine limits occur at relatively low elevations. At the Karelia watershed the prediction underestimates the level for the end of the pollen zone $\mathrm{E} 4 \mathrm{~b}$ and, as before, much higher marine limits are predicted (Fig. 10C). For the Ostrobothnia sites other than Evijärvi, agreement between observations and predictions is good (Fig. 10D) and the one discrepancy may suggest that the adopted age for this isolation is too old by c. $2 \mathrm{kyr}$.

Figure 11 compares the observed and predicted sea levels, with the latter based on the final iteration ice sheet, for all Eemian observations. In the absence of observational or model uncertainties, upper limit observations should lie above the 1:1 line, lower limits should lie below it, and observations of mean sea level should lie on it. The largest contribution to the uncertainty of the predicted values is the age uncertainty and, in so far as the ice history and the observational data are referenced to the same time scale, it is the relative age precision within the Eemian interval that determines the uncertainty of the predicted value. For the European data, where the time scale is determined by the pollen chronology, relative age uncertainties $\sigma_{\mathrm{t}}$ of half the duration of the pollen zone or $1 \mathrm{kyr}$, whichever is the greatest, have been adopted except for the marine limits and the Kola Peninsula elevations for which $\sigma_{\mathrm{t}}=1.5 \mathrm{kyr}$. For the
Russian area, asymmetrical age uncertainties of $+1 \mathrm{kyr}$ and $-\sqrt{ } 2 \mathrm{kyr}$ have been adopted to allow for a possible time-lag of $1 \mathrm{kyr}$ between the eastern and western chronologies. Because the sea-level change may not be linear during the Eemian period, the resulting uncertainties of the predicted values will be asymmetric in most instances. Where a range for the observed sealevel change has been reported the mean value is adopted as the best estimate with uncertainties corresponding to half this range. For the lower limiting estimates a nominal uncertainty of $\pm 5 \mathrm{~m}$ has been adopted.

Agreement between the observed and predicted sea levels is mostly within the uncertain estimates of the two quantities. The two upper-limiting observations from Stenberget and Boliden in Sweden lie well above their predicted counterparts and contain little information. The lower limiting observations lie, within error bars, mostly below the predicted values and the mean sea-level estimates are also mostly consistent with the corresponding observations. For a few points the discrepancies exceed the uncertainty estimates. The prediction for the Karelia watershed (point 1, Fig. 11), as already noted, lies below the observed level and this suggests that the ice thickness could be increased by c. $5 \%$ over this region. The other major discrepancy (points 2 and 3) occurs for marine limit inferences from Svalbard. In view of the uncertainties of the observational data interpretation and of the predictions themselves it is not appropriate to attempt a further iteration for the ice sheet at this time.

\section{Palaeogeographical reconstructions}

If both the past relative sea level $\Delta \zeta(\varphi, t)$ at position $\varphi$ and epoch $t$ and the present-day $t_{0}$ topography $h\left(\varphi, t_{0}\right)$ are known, then the palaeo-topography $h(\varphi, t)$ follows as

$$
h(\varphi, t)=h\left(\varphi, t_{0}\right)-\Delta \zeta(\varphi, t)
$$

If ice of thickness $I(\varphi, t)$ is present, the elevation of the ice surface, expressed with respect to sea level at epoch $t$, is

$$
h(\varphi, t)=h\left(\varphi, t_{0}\right)-\Delta \zeta(\varphi, t)+I(\varphi, t)
$$

For the regional reconstructions presented here we have used the Global DTM5 topographic database (GTECH 1995) with a spatial resolution of $5^{\prime}$ or about $10 \mathrm{~km}$, and this low resolution has two consequences: features such as narrow riverbeds and mountain passes will not be resolved and pass heights will tend to be overestimated. In addition, the ice margins are approximate at best and small changes in their location can determine whether ice-marginal lakes occurred, and the discussion of the control on such 

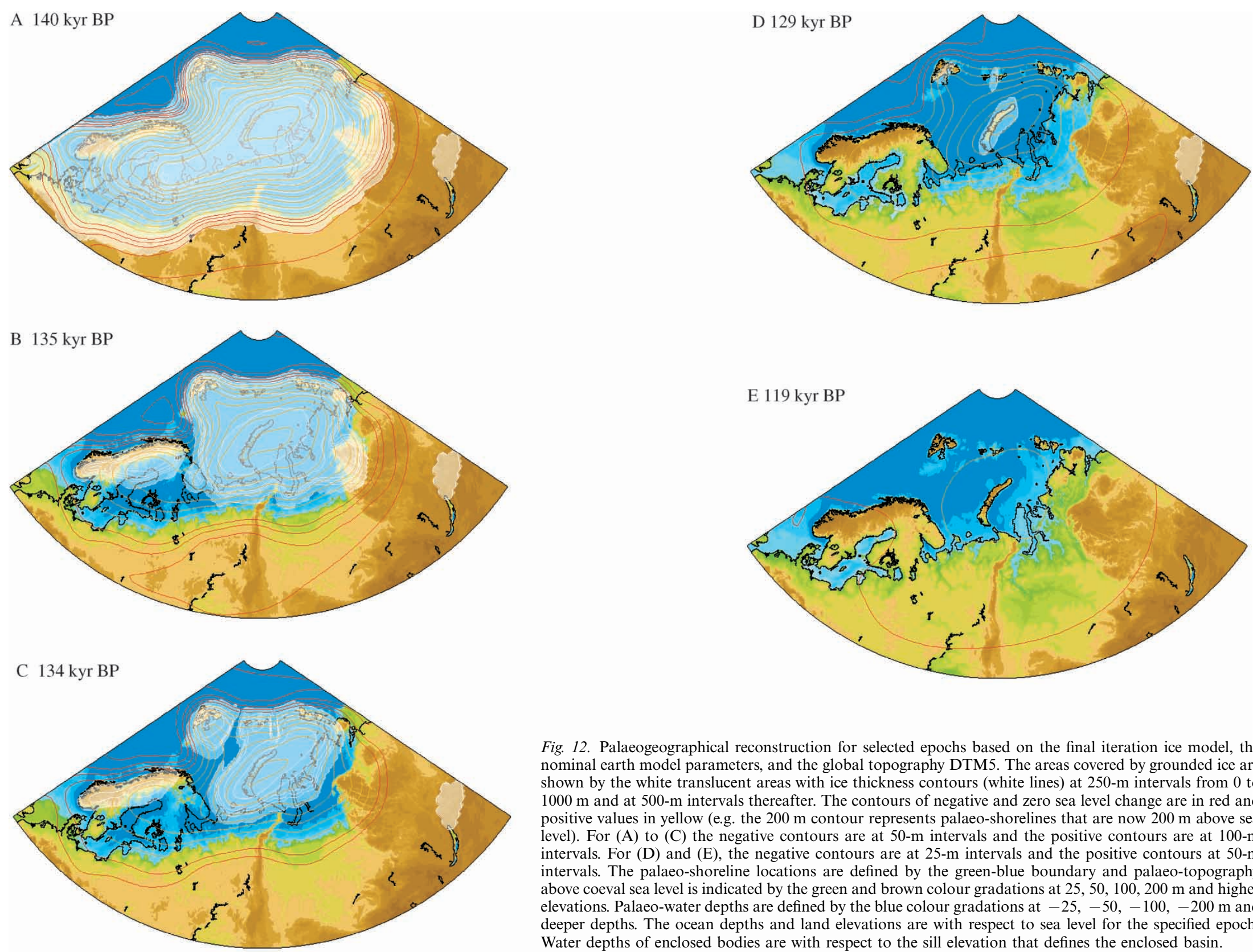

Fig. 12. Palaeogeographical reconstruction for selected epochs based on the final iteration ice model, the nominal earth model parameters, and the global topography DTM5. The areas covered by grounded ice are hown by the white transucent areas with ice thickness contours (white lines) at 250 -m int ground from 0 to postive and at 500 positive values in yellow (e.g. the $200 \mathrm{~m}$ contour represents palaeo-shorelines that are now $200 \mathrm{~m}$ above sea evel). For (A) to (C) the negative contours are at $50-\mathrm{m}$ intervals and the positive contours are at $100-\mathrm{m}$ intervals. For (D) and (E), the negative contours are at $25-\mathrm{m}$ intervals and the positive contours at $50-\mathrm{m}$ intervals. The palaeo-shoreline locations are defined by the green-blue boundary and palaeo-topography above coeval sea level is indicated by the green and brown colour gradations at 25, 50, 100, $200 \mathrm{~m}$ and higher elevations. Palaeo-water depths are defined by the blue colour gradations at $-25,-50,-100,-200 \mathrm{~m}$ and deeper depths. The ocean depths and land elevations are with respect to sea level for the specified epoch. Water depths of enclosed bodies are with respect to the sill elevation that defines the enclosed basin. 
lakes will be focused on mountain passes away from the ice margins. Once the locations of particularly significant sills have been identified, higher resolution digital databases or topographic maps can be used to predict more precisely the timing of inundations or isolations (Lambeck 1999). The accuracy of the topographic data has not been assessed, particularly for the shallow shelf areas of the Arctic Ocean. Figure 12 illustrates representative reconstructions for selected epochs across northern Eurasia, based on the nominal earth model, the final iteration ice model, and the revised Eemian chronology. Shown are ice margins and ice thickness, contours of relative sea-level change, palaeo-elevations and water depths, and the maximum limits of ice-dammed lakes where valleys and basins at the ice margins are filled to the level defined by the minimum sill elevation predicted for each basin or series of interconnected basins. The reconstructions do make the assumption that any alteration of the topography by erosion and sedimentation has been negligible.

\section{From Late Saalian to the end of the Eemian}

At the time of greatest ice advance at c. $140 \mathrm{kyr}$ BP (Fig. 12A) the maximum ice thickness reached was c. $4500 \mathrm{~m}$ over the Kara Sea and c. $4000 \mathrm{~m}$ over the Gulf of Bothnia, with thick ice in between. The maximum crustal depression at the peak Late Saalian glaciation reached c. $1100 \mathrm{~m}$ over the Kara Sea and c. $1000 \mathrm{~m}$ over Finland, such that the maximum elevation of the ice surface reached $c .3500 \mathrm{~m}$ above the sea level. Much of the sub-ice topography that currently forms the lowlands from the North Sea to the Taymyr Peninsula was depressed below coeval sea level and extensive inundation occurs if the ice is removed at a rate that is faster than the isostatic rebound, as will usually be the case. With the retreat of the ice, lakes are predicted at the southern margin of the European part of the ice sheet, being initially isolated from the North Sea and Atlantic (before c. $136 \mathrm{kyr}$ BP) but subsequently open to the ocean through Denmark, and with further retreat through southern Sweden (Fig. 12B). In Siberia, a catchment basin is predicted between the Urals and the Putorana Plateau, including the basins of the $\mathrm{Ob}^{\prime}$ and Yenisey rivers, and during the glacial stage the southern margin of the ice sheet acted as a barrier to the normally northwards flowing rivers (Fig. 12A) with the potential for overflow through the Irtysh-Toboj rivers and Turgay pass of Kazakhstan and into the Aral Sea. But once ice retreat occurred the overflow is predicted to occur through the lower passes of the northern Urals, such as the Sob pass (Fig. 12B), because of the still-substantial crustal depression after the Saalian ice retreat. For example, at $135 \mathrm{kyr}$ BP the Turgay pass is predicted to lie $c .15 \mathrm{~m}$ higher than the Sob pass in the northern Urals (see below). Observational constraints on the predictions of early-Eemian lakes and shorelines of Russia are few, in part because the later Weichselian ice and periglacial lakes will have over-printed much of the older evidence. But in at least one locality in the upper Pechora River, Mangerud et al. (2001a) have identified beach gravels and sands of pre-Eemian age (OSL age of $141 \pm 15 \mathrm{kyr}$ BP) underlying Weichselian lake deposits. The present elevation of the beach deposits is $c .72 \mathrm{~m}$ a.s.l. and equal to the predicted elevation at 136-134 kyr BP.

With further ice retreat, shortly after $135 \mathrm{kyr}$ BP in these reconstructions, the entire northern Siberian plain becomes a marine environment extending into the Khatanga River valley (Fig. 12C). This extensive inundation of the arctic lowlands persists for much of the interglacial and even at the end the lowlands of the $\mathrm{Ob}^{\prime}$ and Yenisey valleys remain inundated because the rebound centred on the Kara Sea is not yet complete (Fig. 12E). In the west, with the first removal of the Late Saalian ice from the North Sea and western Baltic, much of low-lying northern Denmark is submerged by the Atlantic-Baltic connection across northern Jylland and through the Danish Bælts. No opening through Schleswig-Holstein, between the German and Kiel Bights, is predicted, although the palaeoelevations are less than $20 \mathrm{~m}$ and the predictions do not include the possibility of post-Eemian modification of the topography by subsequent Weichselian glaciations. The connection through southern Sweden was more substantial and lasted until after $134 \mathrm{kyr}$ BP (Fig. 12C). Thus, as soon as the ice retreated from these regions the Atlantic waters could penetrate rapidly into northern Europe even while substantial ice remained further north. By $135 \mathrm{kyr}$ BP the Scandinavian ice retreated to northern Finland, Sweden and Norway, but the concomitant rebound was insufficient to prevent extensive inundation of the lowlands and the marine incursion into the Baltic is predicted to have occurred from both the Atlantic and Arctic Oceans, although the northern marine incursion can be readily suppressed if the ice margins extended across the Murmansk region from Finnmark to the Kola Peninsula. Such an ice barrier would not affect the level of inundation, but it would direct flow into the Baltic from the Kara Ice Sheet. The occurrence of cold freshwater sediments at some of the Ostrobothnia sites, below Boreal Eemian deposits, at about the same time that marine or brackish-water deposition occurred further west, lends support to the White Sea having been isolated from arctic marine water during early interglacial time.

After $134 \mathrm{kyr}$ BP the ice sheet has contracted to the present Kara Sea and the arctic islands and there is a marine connection from the Atlantic to the Laptev Sea via the Baltic and Barents Seas and the northern Taymyr Peninsula. The seaway through Karelia now evolves rapidly and is much restricted by $132 \mathrm{kyr} \mathrm{BP}$; final closure of the Karelia watershed occurs soon after 129 kyr BP (Fig. 12D), by which time the Baltic begins to resemble its present form although inundation of 
lowlands still occurs in the Gulf of Finland and along the southern margin of the Baltic Sea. The most detailed observationally based reconstruction of the Boreal Eemian Atlantic-Baltic-White Sea connection is by Funder et al. (2002), and the above model predictions for a narrow seaway connecting the Baltic and White Seas during the E2b and E4a pollen zones are consistent with their data (see their fig. 3).

Consistent model predictions are (i) a relatively long time interval between the time ice retreated from the region and the time of the onset of the Eemian warm period and (ii) a much more extensive marine inundation of the Scandinavian and Russian lowlands during this earliest Eemian interval than during the subsequent warm phase. Thus across the region marine limits are predicted to have been considerably higher than any subsequent warm-period sea levels and the relatively short-lived and restricted early Eemian connection from the Baltic to the White Sea is predicted to have been preceded by a prolonged and extensive coldwater marine connection starting at the time of ice retreat from the Karelia watershed. But observations of sea level for this early period in Europe are limited to some early interglacial marine limits from Svalbard, the evidence for cold-water environments in Ostrobothnia preceding the warm phase of the Eemian, and cold-water brackish-water Late Saalian and earliest Eemian deposits along the southern margin of the Baltic Sea. Our conjecture is that at this early time of rapid uplift and shoreline migration in a shallow Baltic environment of sea ice and large influx of meltwater from both the Scandinavian and Kara ice sheets, there may simply not have been sufficient time for a consistent and clearly recognizable earliest interglacial fauna and flora to develop and/or to be preserved.

This pre-Eemian connection between the Atlantic and the arctic via the Baltic extended eastwards, initially to the Urals and then all the way to the Taymyr Peninsula, and persisted for several thousand years. The introduction of relatively warm Atlantic water into these northern latitudes in earliest Eemian time would have facilitated the very rapid spread of the subsequent Boreal vegetation and marine fauna across the region and may itself be the cause for the warming that occurred at this time across continental northern Europe. During the last glaciation neither the connection between the Baltic and Arctic Ocean nor the extensive inundation of northern Russia occurred and the climate differences between the early Eemian and the Holocene may be primarily palaeogeographic in origin (Zagwijn 1996): a consequence of differences in the last two glacial maxima rather than of differences in climate forcing during the two interglacials. That is, the anomalous interglacial climate conditions of northern Europe may be largely attributable to the anomalous conditions of the previous glaciation.

\section{From Early to Middle Weichselian}

The model predictions indicate that during the stadial MIS-5d, the ice was pinned on the Urals and merged with the Putorana Plateau ice cap such that a large West-Siberian ice-dammed lake occurred between these topographic features (Fig. 13A). In this reconstructions the lake consists of northern and southern basins separated by an east-west topographic high that is cut by the $\mathrm{Ob}$ ' and Taz rivers. The northern basin is similar to that which formed during the Late Saalian, but the southern basin extends the lake much further south into the Omsk and Toms regions with overflow occurring through the Turgay pass into the Aral Sea basin and beyond. This difference between the two epochs is due to the differences in ice thickness at the two epochs and to greater depression of the northern Urals at the earlier time than during MIS-5d. For example, during this latter stadial the predicted sea level at the Sob pass, whose present elevation is $154 \mathrm{~m}$ a.s.1. (Maslenikova \& Mangerud 2001), is $-31 \mathrm{~m}$, such that the elevation of the pass above coeval sea level is c. $185 \mathrm{~m}$ whereas that predicted for the Turgay pass is a few meters lower (Table 8) and this would be the preferred primary overflow. This assumes that the sill height is controlled by the present-day terrain elevation rather than the bedrock elevation which, in the Turgay case has a minimum height of $c .55 \mathrm{~m}$ a.s.l. and occurs about $500 \mathrm{~km}$ north of the present watershed (Mangerud et al. 2004). Thus, if the bedrock elevation controls the lake level then the overflow occurs through the Turgay pass.

The pattern repeats for the MIS-5b glaciation (Fig. 13C), a consequence of the assumed similarities of the Kara ice sheets at the two epochs and of any residual Saalian influence being small by this time. There is therefore potential for overprinting of the sedimentological records from the two stadials, as well as from the Late Saalian in the northern basin and from MIS-4, and this may result in a confused observational record of the lake margin with ages ranging from Late Saalian to Middle Weichselian. This may be why there are very few if any OSL dates from the MIS-5d stage, whereas MIS-5b and MIS-4 ages are more abundant (e.g. Mangerud et al. 2001a, b, 2004). A tentative estimate of the present elevation of the MIS- $5 b$ lake in the lower Ob' valley is $c .60 \mathrm{~m}$ (Mangerud et al. 2004), which gives a palaeo-lake level at $c .122 \mathrm{~m}$ a.s.l. and supports a model in which the overflow occurred through the Turgay pass at the bedrock elevation (Table 8 ).

During the interstadials MIS-5c and 5a the ice has mostly retreated to the Kara Sea and topography for West Siberia is similar to today except that the northern Yamal and Gydan areas remained below sea level (Fig. 13B, D). During the Middle Weichselian stadial MIS-4 the southern ice margin of the Kara Sea lies north of the Urals and Putorana highlands and the 

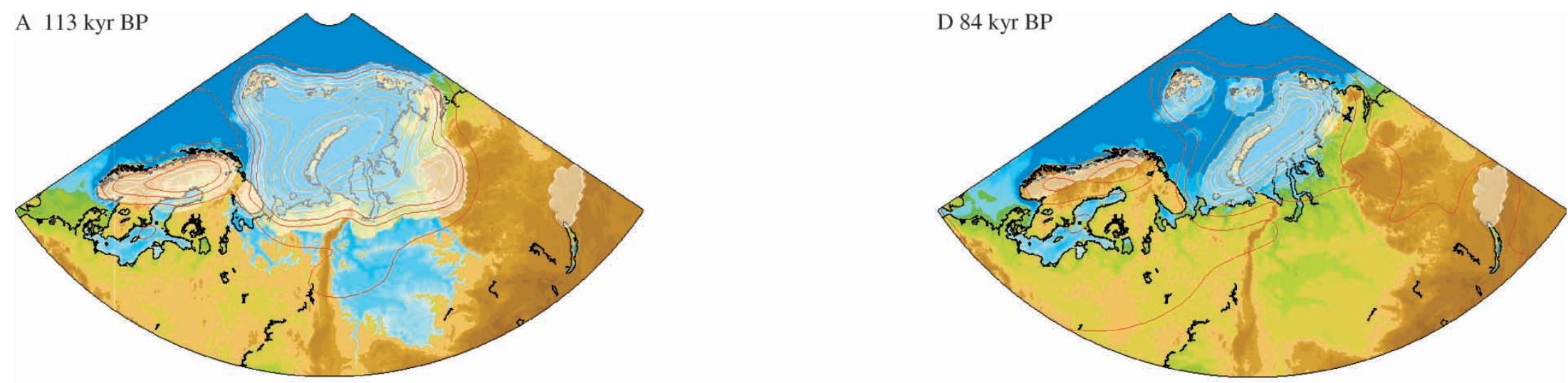

B $106 \mathrm{kyr}$ BP
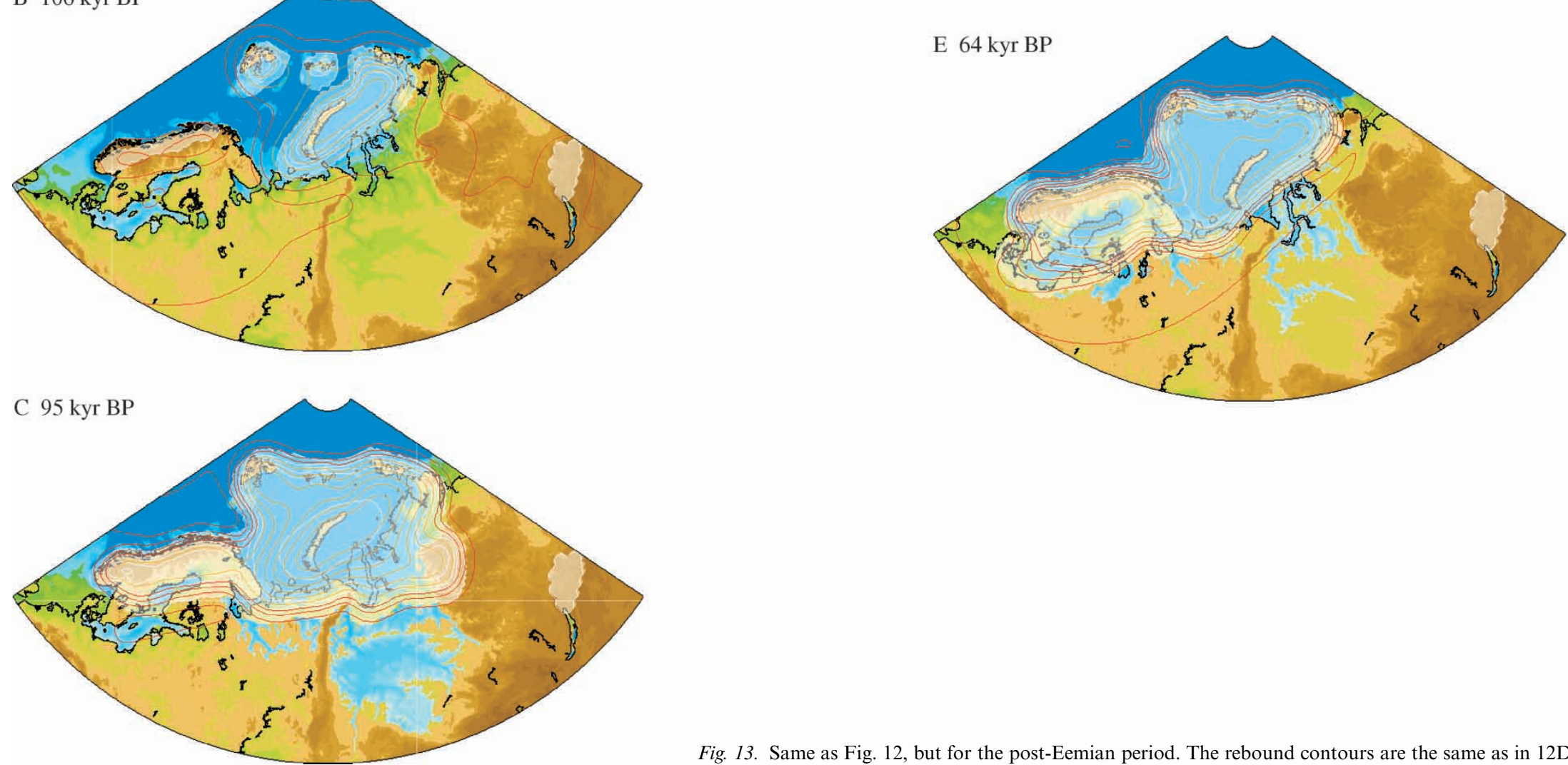
Table 8. Predicted palaeo-elevations at selected sills or other localities for the three Middle-Early Weichselian stadials. $h\left(t_{0}\right)$ is the observed (or inferred) present-day elevation of the pass or sill above sea level; $\Delta \zeta$ is the sea-level change since the epoch $t$; and $h(t)$ is the palaeo-elevation referenced to sea level at epoch. Also included are predicted lake levels at three localities where shorelines have been identified or inferred from sedimentological data. During MIS-5d the predicted elevations for the Turgay bedrock sill and the Ob' site are similar and indicate that the bedrock controlled the lake level at that time.

\begin{tabular}{|c|c|c|c|c|c|c|c|}
\hline Location & $\begin{array}{l}h\left(t_{0}\right) \\
\text { (m a.s.1.) }\end{array}$ & $\begin{array}{l}\Delta \zeta \\
(t=64 \mathrm{kyr}) \\
(\mathrm{m} \text { a.s.l. })\end{array}$ & $\begin{array}{l}\Delta \zeta \\
(t=95 \mathrm{kyr}) \\
(\mathrm{m} \text { a.s.l. })\end{array}$ & $\begin{array}{l}\Delta \zeta \\
(t=113 \mathrm{kyr}) \\
(\mathrm{m} \text { a.s.l. })\end{array}$ & $\begin{array}{l}h \\
(t=64 \mathrm{kyr}) \\
(\mathrm{m} \text { a.s.l. })\end{array}$ & $\begin{array}{l}h \\
(t=95 \mathrm{kyr}) \\
\text { (m a.s.l.) }\end{array}$ & $\begin{array}{l}h \\
(t=113 \mathrm{kyr}) \\
\text { (m a.s.l.) }\end{array}$ \\
\hline \multicolumn{8}{|l|}{ Pass locations } \\
\hline Sob (polar Urals) ${ }^{1}$ & 154 & -81 & -31 & -31 & 235 & 185 & 185 \\
\hline Turgay (topographic) ${ }^{2}$ & 126 & -68 & -52 & -57 & 194 & 178 & 183 \\
\hline Turgay (bedrock) ${ }^{3}$ & 55 & -67 & -52 & -53 & 122 & 107 & $108<$ \\
\hline Tsilma (Timan Ridge) ${ }^{4}$ & 113 & -54 & -23 & -32 & 167 & 136 & 145 \\
\hline Karelia watershed & 105 & -92 & -75 & -63 & 197 & 180 & 168 \\
\hline Mylva $^{5}$ & 140 & -76 & -62 & -53 & 216 & 202 & 193 \\
\hline Mylva (bedrock) & 100 & -76 & -62 & -53 & 176 & 162 & 153 \\
\hline Keltma $^{6}$ & 132 & -74 & -59 & -54 & 206 & 191 & 186 \\
\hline Keltma (bedrock) & 104 & -74 & -59 & -54 & 178 & 163 & 158 \\
\hline \multicolumn{8}{|l|}{ Other localities } \\
\hline Byzovaya (Pechora) & 90 & -80 & -62 & -50 & 170 & 152 & 140 \\
\hline Garevo (Pechora) & 100 & -71 & -41 & -40 & 171 & 144 & 140 \\
\hline Ob'-Sangompan & 60 & -76 & -62 & -50 & 136 & 122 & $110<$ \\
\hline
\end{tabular}

${ }^{1}$ Maslenikova \& Mangerud (2001). ${ }^{2}$ Mangerud et al. (2004). ${ }^{3}$ For a location $500 \mathrm{~km}$ north of Turgay pass. ${ }^{4}$ Astakhov et al. (1999). ${ }^{5}$ The watershed between the Pechora and Dvina basins at $62.0^{\circ} \mathrm{N} 55.3^{\circ} \mathrm{E} .{ }^{6} \mathrm{The}$ watershed between the Dvina and Volga basins at $60.9^{\circ} \mathrm{N} 54.6^{\circ} \mathrm{E}$.

Siberian lake limits are now controlled by the ice margins on the Taymyr Peninsula and Pechora lowland (Fig. 13E). Extensive flooding of the Ob', Yenisey and Taz lowlands is predicted but the maximum lake limits of the earlier stadials are not reached because of the occurrence of ice-free lower elevation sills further west along the ice margin.

To the west of the Urals, the prediction of icedammed lakes is largely controlled by the position of the ice margins over Pechora and Arkhangelsk-Mezen basins, and any palaeogeographic reconstructions are critically dependent on the assumed location of the southern ice margin. As indicated above, the assumed ice margins may extend too far south during the Stage 5 and Stage 4 stadials over the Arkhangelsk-Mezen region (Larsen et al., 2006) and this will impact on the reconstructions and the results presented here are to be considered as indicative of what can be achieved with these models rather than presenting a definitive answer to the palaeo-drainage between the Timan Ridge and the White Sea. Also, higher resolution topography than that used here is required in any more detailed analysis. The predictions for the two stage-5 stadials are similar and, for both, a lake is predicted between the Urals and Timan Ridge dammed by ice that is pinned on these two topographic features and whose elevation is controlled by the elevation of the lowest pass in the Timan Ridge near Tsilma (Fig. 13A, C). This corresponds to Komi Lake (Mangerud et al. 2001a). A second ice lake is predicted for both epochs over the White Sea and Arkhangelsk region dammed by an ice ridge extending from the Pechora Sea to the Kola Peninsula in the case of MIS-5d and by the thicker ice ridge extending to Scandinavia in the case of MIS-5b.
This corresponds to the White Sea Lake of Mangerud et al. (2001a). However, this lake during MIS-5d is critically dependent on the existence of a Kola or Ponoi ice dome and the occurrence or not of a lake here, or evidence of this lake's dimensions, can be used as evidence for or against such ice cover. Both reconstructions are similar to that proposed by Mangerud et al. (2001a, 2004) for $90000 \mathrm{kyr}$ BP. Mangerud et al. also assumed that during MIS-5b the Kara ice ridge extended from the Kara Sea to Scandinavia, any differences being mainly the result of the incorporation of the isostatic contributions in the present reconstructions. Potential overflows of Komi Lake are through the Timan Ridge at the Tsilma pass (presently at $c$. $113 \mathrm{~m}$ a.s.l., Astakhov et al. 1999), through the Sob pass in the Urals, or into the Kama-Volga drainage system over the Mylva pass (Maslenikova \& Mangerud 2001). Potential overflows of the White Sea Lake are via Karelia or a southwards flow through the Dvina valley and over the Keltma pass (Maslenikova \& Mangerud 2001). Depending on the extent of ice cover over the Kola Peninsula, possible outflow could also occur via the Kola River, but we have not considered this possibility further. Table 8 summarizes the predicted palaeo-elevations of these passes (and other localities) for the three stadials 5d, 5b and 4 and Fig. 14 illustrates schematically the possible connections. At both MIS-5d and 5b, the Tsilma pass lies at a lower elevation than the Karelia pass and both lie below the elevation of the Sob pass (Table 8). Thus both lakes are at the same level and there is no eastwards flow through the Urals. The Mylva and Keltma sills are predicted to lie above Karelia for both epochs, but if the bedrock elevations of the former are used, then the 
Fig. 14. Schematic representation of the connection between the ice-dammed lakes at the southern margin of the ice sheet at the time of MIS-5b. The pass elevations of the topographic surface, with respect to sea level at this time, are indicated as well as the bedrock elevations for Turgay, Mylva and Kelima. At this time, the West Siberia ice-dammed lake is predicted to have overflowed through the Turgay pass and the overflow of Komi Lake is

predicted to have occurred via the Tsilma pass into the White Sea area. If the White Sea is ice-dammed at this time the lake level is controlled by the Keltma pass and the overflow is into the Kama-Volga drainage system.

controlling sill occurs at the Keltma sill. Present-day lake levels in the upper Pechora valley near the MIS-5b ice margin are $c .90 \mathrm{~m}$ a.s.1. at Byzovaya and $c .100 \mathrm{~m}$ a.s.l. at Garevo (Mangerud et al. 2001a); their predicted palaeo-elevations are $c$. $140-150 \mathrm{~m}$ a.s.l. (Table 8), closer to the Mylva and Keltma sill elevations than to the elevation of the Karelia watershed, and the inference is that the drainage of the two interconnected lakes is southwards into the Kama-Volga system.

In contrast to the above interpretation, Larsen et al. (2006) argue that the Early Weichselian ice-dammed lake was restricted to the Pechora lowland and that the drainage occurred through the Timan Ridge and via an ice-free corridor between the Barents and Scandinavian ice. This resembles the reconstruction for Stage MIS-5d without the Ponoi ice dome, and the model predictions indicate that in this case any southern drainage of the lake is excluded. Once the lake level is controlled by the Timan Ridge there is also closer consistency with the above-cited lake level observations in the upper Pechora valley. One implication of the Larsen et al. interpretation is that the ice-free corridor existed through both Early Weichselian stadials, and the existence or not of a White Sea Lake at any time during the Early Weichselian remains controversial (cf. Mangerud et al. 2004) and one that the current modelling cannot resolve.

For the Middle Weichselian stadial MIS-4 reconstruction (Fig. 13E) Komi Lake is controlled in the east by the ice margin and small shifts in its location will cause any lake to drain eastwards into the Siberian Lake system and then southwards via the Turgay bedrock pass unless the ice in the east is not pinned on the Taymyr Peninsula. The predicted White Sea Lake at this time is restricted to the Dvina basin with the overflow occurring eastwards through the Timan Ridge rather than southwards since the Keltma bedrock elevation is predicted to have been some $20 \mathrm{~m}$ above the Tsilma pass (Table 8). This is consistent with the evidence as presented by Larsen et al. (2006). An expanded Lake Ladoga is predicted along the southeastern margin of the Scandinavian ice, but this is also ice-margin rather than rock-topography controlled.

\section{Discussion and conclusions}

In reaching the solution adopted here we started with a preliminary ice model based on a series of observational and glaciological assumptions. With this model we predicted rebound outcomes and used the discrepancies between observations and predictions to improve upon the ice model. Such a process removes the restrictions placed on the starting model provided that the observational database is adequate. Thus, while we start with an assumption of frozen basal conditions, the final ice sheet profiles are flatter than such a model assumes and the final model is independent of this assumption: if we were to start with different startingmodel assumptions the solution should converge to the same model. This approach has worked well for analyses of the Late Weichselian ice sheet (Lambeck 1995; Lambeck et al. 1998b; Lambeck \& Purcell 2003) and, within the limitations of the data set, appears to work here and inversion does constrain the ice sheets from Late Saalian to Middle Weichselian time. In 
particular, during the penultimate glaciation the ice extended as a single entity across northern Europe and Russia with a broad ridge from the Kara Sea to Karelia, reaching a maximum thickness of $c .4500 \mathrm{~m}$ and a maximum ice surface elevation of $c .3500 \mathrm{~m}$ a.s.1. In the starting model the ice sheet was represented by two loci of ice concentration, over the Kara Sea and over the Gulf of Bothnia, and while successive iterations have reduced the height difference between the domes and the saddle, this feature appears to be a robust one. The crustal depression beneath this ice was such that when the ice retreated from the lowlands extensive marine flooding occurred during latest Saalian and early Eemian time that extended from the Atlantic to the Laptev Sea. Such an inundation of relatively warm Atlantic waters into the arctic may provide an explanation for the very rapid expansion of the interglacial boreal flora and warm-water marine fauna from west to east during the early Eemian and may offer an explanation for the abnormally warm conditions observed across the region throughout this interval. This begs the question, are the abnormally warm Eemian conditions of northern Europe more a consequence of an abnormally large ice sheet during MIS-6 than of climate forcing conditions during the interglacial itself?

Within the model assumptions for the ice margin limits of the principal ice stages, and that changes in ice volume of the Eurasian ice are in phase with the global changes inferred from sea-level data, the prediction of the marine inundation preceding and during the warm boreal phase of early Eemian time is robust and independent of other model assumptions such as earth rheology and ice-margin movements between the successive stadials. Observational evidence for this phase is limited, but not absent, and we infer that this early record has either not been well preserved or that during the late stages of the Saalian deglaciation local, but thin, ice remained. Also, the model predictions for falling sea levels throughout the Eemian for the locations well within the ice margins, for example in Ostrobothnia and at the Karelia watershed, appear to be robust. In particular, no model parameters have been identified that result in a transgressive phase followed by a regression with the peak occurring during the early Eemian at high enough elevations to keep an open Baltic-White Sea passage. Only closer to the margins of the former ice sheet, such as at Vaga in the southern part of the Dvina Basin, are such 'Litorina' signals predicted.

For the Scandinavian part of the Late Saalian ice sheet, the distance out to the edge of the ice margin at the time of maximum glaciation $\mathrm{s}_{\max }\left(\mathrm{t}_{\max }\right)$ is c. $1000 \mathrm{~km}$, and with equations (1) and (2) this implies an average basal shear stress of $c$. $30-35 \mathrm{kPa}$. This is not inconsistent with values found for present-day ice sheets or with values inferred for Late Weichselian ice sheets (Paterson 1994: pp. 169 and 242) and consistent with the deformation occurring in part in till layers at the base of the ice sheet. For the Russian area, $\mathrm{s}_{\max }\left(\mathrm{t}_{\max }\right) \approx 1500 \mathrm{~km}$ and the average basal shear stress is similar to that for Scandinavia at this epoch.

The observational constraints for the Early Weichselian glaciations are even more limited than those for the interglacial period, but they are consistent with the existence of extensive ice sheets over arctic Russia centred on the Kara Sea. These ice sheets over Russia were significantly thinner than the Late Saalian ice sheet, with maximum thickness of $c .1200 \mathrm{~m}$. The resulting basal stresses are also considerably lower (c. $10 \mathrm{kPa}$ ) than for the earlier period. This implies a greater degree of deformation within sediments at the base of the ice sheet during these latter intervals than during the Late Saalian and is consistent with much of the advance and retreat occurring over the shallow Kara and Barents Seas and arctic coast.

With the model predictions for the crustal rebound through time it becomes possible to reconstruct the palaeo-topography including the limits and water depths of ice-dammed lakes. The resulting predictions for West Siberia are consistent with much of the observational evidence and point to an overflow of the Early Weichselian lakes occurring initially through the Turgay pass and into the Aral Sea basin. In contrast, the predictions for the MIS-4 lakes point to an overflow north of the Urals and westwards via the Pechora lowlands. The current model is also consistent with observations for Komi Lake west of the Urals during the Early Weichselian stages MIS-5d and 5b, with the overflow predicted to occur into the Arkhangelsk-Dvina basin and then via Karelia into the Baltic. The level of this lake is controlled not only by the palaeo-topography of the Timan Ridge and of the upper Pechora-Mylva rivers, but also by the existence or otherwise of grounded ice between the BarentsKara Seas and the Kola Peninsula. If the $5 \mathrm{~d}$ and/or $5 \mathrm{~b}$ ice dammed the White Sea, then the resulting White Sea Lake will be at the same level as Lake Komi and at the same level as the Keltma pass, assuming that the palaeo-level of the bedrock surface is the appropriate control. If the White Sea was unconfined then the Komi Lake level is controlled by the Timan Ridge and the level will be some $13 \mathrm{~m}$ lower. The observational evidence from the upper Pechora valley (Mangerud et al. 2001) is consistent with an un-dammed White Sea.

While the Early Weichselian ice sheets are areally large, their volumes are relatively small when compared with the oscillations in global sea level at this time. Whether this imbalance can be attributed to large fluctuations in the North American ice sheet during isotope stages 5 and 4 remains unclear, as models for this period generally indicate ice volumes that are less than required to make up the deficit and possibly there is an Antarctic contribution on these time scales as well. But within the accuracies of the current model 
and data constraints the present conclusions are not sensitive to how the imbalance is distributed between the North American and Antarctic ice sheets.

One of the by-products of the analysis is an estimate of the isostatic corrections for early Eemian sea-level data in the North Sea and for northern Germany. Thus sea-level observations from different North Sea and Baltic localities can be reduced to a common locality and any lag in the local sea-level rise, resulting from the isostatic response, can be evaluated and used to establish the relation between the relative pollen chronology for the Eemian and the absolute time scale defined by the sea-level curves established at far-field sites and constrained by the U/Th coral chronology. For example, for the Müller (1974) and Zagwijn (1996) chronology, the onset of the pollen zone E1 occurs at $131 \mathrm{kyr} \mathrm{BP}$, and the end of the pollen zone E4b, corresponding to the end of the rapid rise noted in the Netherlands and North Sea, occurs at $128 \mathrm{kyr}$ BP. The establishment of the relationship between the pollen chronology and the global glacial chronology is critical as far as the ice thickness estimates are concerned, and the primary reason for the increased ice volume in the later iteration solutions compared to the starting model is the change in chronology. The relative form of the Late Saalian ice sheet, however, remains essentially unchanged by the rescaling.

As new information on the ages, elevations and locations of lake and marine shorelines, as well as new constraints on ice margins, become available the analysis will undoubtedly require revision. New data that would be particularly welcome include ages for the Kola Peninsula shorelines, information from northern Scandinavia and Novaya Zemlya, from the southern Baltic, elevations and ages of marine limits, information on the spatial gradients of sea-level change along, for example, the Yenisey and $\mathrm{Ob}^{\prime}$ rivers as well as across the Taymyr Peninsula, and elevations and spatial gradients of the ice-dammed lakes.

Acknowledgements. - The work by the first author was funded by the Swedish Research Council's Tage Erlander Professorship award, the Australian National University and the Australian Research Council. The fieldwork was funded through the European Community project 'Eurasian Ice Sheets' (contract ENV4-CT970563), the Norwegian Research Council, the Danish Natural Science Research Council (CLIENT and TripleJunction projects), the Swedish Polar Secretariat, the Norwegian Barents Secretariat and the Swedish Crafoord Foundation. This is a contribution to the European Science Foundation 'QUEEN' programme (Quaternary Environment of the Eurasian North) and the Norwegian Research Council 'NORPAST' programme (Past Climates of the Norwegian Region).

\section{References}

Alexanderson, H., Adrielsson, L., Hjort, C., Möller, P., Antonov, O., Eriksson, S. \& Pavlov, M. 2002: The North Taymyr ice-marginal zone, Siberia - a landsystem approach. Journal of Quaternary Science 17, 361-382. van Andel, T. H. 2003: Glacial environments I: the Weichselian climate in Europe between the end of the OIS- 5 interglacial and the Last Glacial Maximum. In van Andel, T. H. \& Davies, W. (eds): Neanderthals and Modern Humans in the European Landscape During the Last Glaciation, 9-19. McDonald Institute for Archaeological Research, Cambridge.

Andersson, T., Forman, S., Ingölfsson, Ó. \& Manley, W. F. 1999: Late Quaternary palaeoenvironmental history of central Prins Karls Forland, western Svalbard. Boreas 28, 292-307.

Arnold, N. S., van Andel, T. H. \& Valen, V. 2003: Extent and dynamics of the Scandinavian Ice Sheet during Oxygen Isotope Stage 3 (65,000-25,000 yr B.P.). Quaternary Research 57, 38-48.

Astakhov, V. 1992: The last glaciation in West Siberia. Sveriges Geologiska Undersökning Ser. Ca 81, 21-30.

Astakhov, V. I., Svendsen, J. I., Matiochkov, A., Mangerud, J., Maslenikova, O. \& Tveranger, J. 1999: Marginal formations of the last Kara and Barents ice sheets in northern European Russia. Boreas 28, 23-45.

Baumann, K. H., Lackschewitz, K. S., Mangerud, J., Spielhagen, R. F., Wolf-Welling, T. C. W., Henrich, R. \& Kassens, H. 1995: Reflection of Scandinavian ice sheet fluctuations in Norwegian Sea sediments during the past 150,000 years. Quaternary Research 43, 185-197.

Beets, D. J. \& Beets, C. J. 2003: A high resolution stable isotope record of the penultimate deglaciation in lake sediments below the city of Amsterdam, The Netherlands. Quaternary Science Reviews 22, 195-207.

Berglund, B. E. \& Lagerlund, E. 1981: Eemian and Weichselian stratigraphy in south Sweden. Boreas 10, 323-362.

Bergsten, H., Andersson, T. \& Ingólfsson, Ó. 1998: Foraminferal stratigraphy of raised marine deposits, representing isotope stage 5 , Prins Karls Forland, western Svalbard. Polar Research 17, 81-91.

Bolshiyanov, D. Y. \& Makeyev, V. M. 1995: Archipelago of Severnaya Zemlya: Environmental History. 216 pp. St. Petersburg, Gidrometeoizdat.

Boulton, G. S., Dongelmans, P., Punkari, M. \& Broadgate, M. 2001: Palaeoglaciology of an ice sheet through a glacial cycle: the European ice sheet through the Weichselian. Quaternary Science Reviews 20, 591-625.

Cadek, O. \& Fleitout, L. 2003: Effect of lateral viscosity variations in the top $300 \mathrm{~km}$ on the geoid and dynamic topography. Geophysical Journal International 152, 566-580.

Caspers, G., Merkt, J. \& Müller, H. 2002: The Eemian interglaciation in Northwestern Germany. Quaternary Research 58, 49-52.

Clark, P. U., Clauge, J. J., Curry, B. B., Dreimanis, A., Hicock, S. R., Miller, G. H., Berger, G. W., Eyles, N., Lamothe, M., Miller, B. B., Mott, R. J., Oldale, R. N., Stea, R. R., Szabo, J. P., Thorleifson, L. H. \& Vincent, J.-S. 1993: Initiation and development of the Laurentide and Cordilleran ice sheets following the Last Interglaciation. Quaternary Science Reviews 12, 79-114.

Denton, G. H. \& Hughes T. J. (eds.) 1981: The Last Great Ice Sheets. 484 pp. Wiley, New York.

Drozdowski, E. 1995: Proximal glaciomarine tills in the northern Lower Vistula region. In Ehlers, J., Kozarski, S. \& Gibbard, P. L. (eds.): Glacial Deposits in North-East Europe, 293-307. A. A. Balkema, Rotterdam.

Drozdowski, E. \& Federowicz, 1987: Stratigraphy of Vistulan glaciogenic deposits and corresponding thermoluminescence dates in the lower Vistula region, northern Poland. Boreas 16, 139-155.

Dziewonski, A. M. \& Anderson, D. L. 1981: Preliminary reference Earth model. Physics of the Earth and Planetary Interiors 25, $297-$ 356.

Ehlers, J., Eissman, L., Lippstrue, L., Stephan, H.-J. \& Wansa, S. 2004: Pleistocene glaciations of North Germany. In Ehlers, J. \& Gibbard, P. (eds.): Quaternary Glaciations - Extent and Chronology Part I: Europe, 135-146. Elsevier, Amsterdam.

Ehlers, J. \& Gibbard, P. L. 2003: Extent and chronology of glaciations. Quaternary Science Reviews 22, 1561-1568. 
Ehlers, J. \& Gibbard, P. L. 2004: (eds.): Quaternary Glaciations Extent and Chronology Part I: Europe. 475 pp. Elsevier, Amsterdam.

Eriksson, B. 1993: The Eemian pollen stratigraphy and vegetational history of Ostrobothnia, Finland. Geological Survey of Finland, Bulletin 372, 36 pp.

Eronen, M., Glückert, G., Hatakka, L., van de Plassche, O., van der Plicht, J. \& Rantala, P. 2001: Rates of Holocene isostatic uplift and relative sea-level lowering of the Baltic in SW Finland based on studies of isolation contacts. Boreas 30, 17-30.

Esat, T. M., McCulloch, T., Chapell, J., Pillans, B. \& Omura, A. 1999: Rapid fluctuations in sea level recorded at Huon Peninsula during the penultimate deglaciation. Science 283, 197-201.

Forman, S. L. \& Miller, G. 1984: Time-dependent soil morphologies and pedogenic processes on raised beaches, Bröggerhalvöya, Spitsbergen, Svalbard archipelago. Arctic and Alpine Research 16 , $381-394$.

Funder, S. \& Balic-Zunic, T. 2006: Hypoxia in the Eemian: mollusc faunas and sediment minerology from Cyprina clay in the southern Baltic region. Boreas 35, 367-378.

Funder, S., Demoidov, I. N. \& Yelovicheva, Y. 2002: Hydrography and mollusc faunas of the Baltic and the White Sea-North Sea seaway in the Eemian. Palaeogeography, Palaeoclimatology, Palaeoecology 184, 275-304.

Garcia Ambrosiana, K. 1990: Pleistocene stratigraphy in Central and Northern Sweden - a reinvestigation of some classical sites. Department of Quaternary Research Report, Stockholm 16, 1-15.

Grichuk, V. P. 1984: Late Pleistocene vegetation history. In Velicko, A. A. (ed.): Late Quaternary Environments of the Soviet Union, 155-178. Longman, London.

Grönlund, T. 1991a: New corings from Eemian interglacial marine deposits in Ostrobothnia, Finland. Geological Survey of Finland, Bulletin 352, 23 pp.

Grönlund, T. 1991b: The diatom stratigraphy of the Eemian Baltic Sea on the basis of sediment discoveries in Ostrobothnia, Finland. Geological Survey of Finland, Report of Investigations 102, 26 pp.

Grøsfjeld, K., Funder, S., Seidenkrantz, M.-S., \& Glaister, C. 2006 Last interglacial marine environments in the White Sea region, northwestern Russia. Boreas 35, 493-520 (this issue).

Gudina, V. I. 1966: Foraminifers, Stratigraphy and Palaeozoogeography of the Marine Pleistocene in the Northern USSR. 132 pp. Nauka Publication, Novosibirsk (in Russian).

Gudina, V. I., Kryukov, V. D., Levchuk, L. K. \& Sudkov, L. A. 1983: Upper-Pleistocene sediments in north-eastern Taymyr. Bulletin of Commission on Quaternary Researches 52, 90-97 (in Russian).

Gudina, V. I., Nuzhdina, N. A. \& Troitskiy, S. L. 1968: New data on the marine Pleistocene of the Taymyr Lowland. Akademiya Nauk SSSR, Sibirskoe Otdelenie. Geologia $i$ Geofizika 1, 40-48 (in Russian).

Gudina, V. I. \& Yevzerov, V. Y. 1973: The Stratigraphy and Foraminifera of the Upper Pleistocene in the Kola Peninsula. 192 pp. The British Library Board 1981 (translated by E. Lees and edited by M. Hughes).

Helmens, K. F., Rasanen, M. E., Johansson, P. W., Jungner, H. \& Korjonen, K. 2000: The Last interglacial-Glacial cycle in NE Fennoscandia: a nearly continuous record from Soki (Finnish Lapland). Quaternary Science Reviews 19, 1605-1623.

Hjort, C., Möller, P. \& Alexanderson, H. 2004: Weichselian glaciation of the Taymyr Peninsula, Siberia. In Ehlers, J. \& Gibbard, P. (eds.): Quaternary Glaciations - Extent and Chronology Part I Europe, 359-367. Elsevier, Amsterdam.

Houmark-Nielsen, M. 1999: A lithostratigraphy of Weichselian glacial and interstadial deposits in Denmark. Bulletin of the Geological Society of Denmark 46, 101-114.

Houmark-Nielsen, M. 2004: The Pleistocene of Denmark: a review of stratigraphy and glacial history. In Ehlers, J. \& Gibbard, P. (eds.): Quaternary Glaciations - Extent and Chronology Part I: Europe, 35-46. Elsevier, Amsterdam.
Houmark-Nielsen, M., Demidov, I., Funder, S., Grøsfjeld, K., Kjær, K. H., Larsen, E., Lavrova, N., Lyså, A. \& Nielsen, J. K. 2001: Early and Middle Valdaian terrestrial and marine based glaciations and periglacial interstadials in North West Russia: new evidence from the Pyoza river area. Global and Planetary Change 31, 215237.

Houmark-Nielsen, M. \& Kjær, K. H. 2003: Southwest Scandinavia, 40-15 kyr: palaeogeography and environmental change. Journal of Quaternary Science 18, 769-786

Hütt, G., Jungner, H., Kujansuu, R. \& Saarnisto, M. 1993: OSL and TL dating of buried podsol and overlying sands on Ostrobothnia, western Finland. Journal of Quaternary Science 8, 125-132.

Jensen, M., Larsen, E., Demidov, I., Funder, S. \& Kjær, K. H. 2006: Depositional environments and sea level changes deduced from Middle Weichselian tidally influenced sediments, Arkhangelsk region, northwestern Russia. Boreas 35, 521-538 (this issue).

Kind, N. V. \& Leonov, B. N. 1982: Antropogen Taimyra (The Anthropogene of Taymyr Peninsula). 184 pp. Nauka, Moscow.

Kjær, K. H., Demidov, I. N., Larsen, E., Murray, A. \& Nielsen, J. K. 2003: Mezen Bay - a key area for understanding Weichselian glaciations in northern Russia. Journal of Quaternary Science 18, 73-93.

Kjær, K. H., Houmark-Nielsen, M. \& Richardt, N. 2003a: Ice-flow patterns and dispersal of erratics at the southwestern margin of the last Scandinavian Ice Sheet: signature of palaeo-ice streams. Boreas $32,130-148$.

Kjær, K. H., Larsen, E. \& Funder, S. 2006a: Late Quaternary in northwestern Russia - Introduction. Boreas 35, 391-393 (this issue).

Kjær, K. H., Larsen, E., Funder, S., Demidov, I., Jensen, M., Håkansson, L. \& Murray, A. 2006b: Eurasian ice sheet interaction in northwestern Russia throughout the late Quaternary. Boreas 35, 444-475 (this issue).

Kleman, J., Fastook, J. \& Stroeven, A. P. 2002: Geologically and geomorphologically constrained numerical model of Laurentide Ice Sheet inception and build-up. Quaternary International 95-6, 87-98.

Kooi, H., Johnston, P., Lambeck, K., Smither, C. \& Molendijk, R. 1998: Geological causes of recent (100 yr) vertical land movement in the Netherlands. Tectonophysics 299, 537-558.

Kosack, B. \& Lange, W. 1985: das Eem-Vorkommen von Offenbütte/ Schnittlohe und die Ausbreitung des Eem-Meeres zwischen Nordund Ostsee (in German). Geologisches Jahrbuch A86, 3-17.

Lagerbäck, R. \& Robertsson, A. M. 1988: Kettle holes - stratigraphical archives for Weichselian geology and palaeoenvironment in northernmost Sweden. Boreas 17, 439-468.

Lambeck, K. 1995: Constraints on the Late Weichselian ice sheet over the Barents Sea from observations of raised shorelines. Quaternary Science Reviews 14, 1-16.

Lambeck, K. 1999: Shoreline displacements in southern-central Sweden and the evolution of the Baltic Sea since the last maximum glaciation. Journal of the Geological Society, London 156, 465-486.

Lambeck, K. \& Chappell, J. 2001: Sea level change through the last Glacial cycle. Science 292, 679-686.

Lambeck, K. \& Johnston, P. 1998: The viscosity of the mantle: evidence from analyses of glacial rebound phenomena. In Jackson, I. (ed.): The Earth's Mantle, 461-502. Cambridge University Press, Cambridge.

Lambeck, K. \& Purcell, A. 2003: Glacial rebound and crustal stress in Finland. Posiva Report 2003-10, 84 pp.

Lambeck, K., Smither, C. \& Ekman, M. 1998a: Tests of glacial rebound models for Fennoscandinavia based on instrumented seaand lake-level records. Geophysical Journal International 135, 375387.

Lambeck, K., Smither, C. \& Johnston, P. 1998b: Sea-level change, glacial rebound and mantle viscosity for northern Europe. Geophysical Journal International 134, 102-144. 
Lambeck, K., Purcell, A. Johnston, P., Nakada, M. \& Yokoyama, Y. 2003: Water-load definition in the glacio-hydro-isostatic sea-level equation. Quaternary Science Reviews 22, 309-318.

Landvik, J. Y., Bolstad, M., Lycke, K., Mangerud, J. \& Sejrup, H. P. 1992: Weichselian stratigraphy and paleoenvironments at Bellsund, Western Svalbard. Boreas 21, 335-358.

Larsen, E., Funder, S. \& Thiede, J. 1999a: Late Quaternary history of northern Russia and adjacent shelves - a synopsis. Boreas 28, $6-$ 11 .

Larsen, E., Kjær, K. H., Demidov, I., Funder, S., Grøsfjeld, K., Houmark-Nielsen, M., Jensen, M., Linge, H. \& Lyså, A. 2006: Late Pleistocene glacial and lake history of northwestern Russia. Boreas 35, 394-424 (this issue).

Larsen, E., Lyså, A., Demidov, I., Funder, S., Houmark-Nielsen, M., Kjær, K. H. \& Murray, A. S. 1999b: Age and extent of the Scandinavian ice sheet in northwest Russia. Boreas 28, 115-132.

Larsen, E., Sejrup, H. P., Janocko, J., Landvik, J. Y., Stalsberg, K. \& Steinsund, P. I. 2000: Recurrent interaction between the Norwegian Channel Ice Stream and terrestrial-based ice across southwest Norway. Boreas 29, 185-203.

Lavrova, M. A. 1960: Quaternary Geology of the Kola Peninsula. 234 pp. Academy of Sciences, USSR, Moscow-Leningrad (in Russian).

Liivrand, E. 1992: Problems of reconstructing Pleistocene stratigraphy in Estonia. Sveriges Geologiska Undersökning Ca 81, 171-176.

Lundqvist, J. 1992: Glacial stratigraphy in Sweden. Geological Survey of Finland, Special Paper 15, 43-59.

Lundqvist, J. 2004: Glacial history of Sweden. In Ehlers, J. \& Gibbard, P. L. (eds.): Quaternary Glaciations - Extent and Chronology Part I: Europe, 401-412. Elsevier, Amsterdam.

Lyså, A., Demidov, I., Houmark-Nielsen, M. \& Larsen, E. 2001: Late Pleistocene stratigraphy and sedimentary environment of the Arkangelsk area, northwest Russia. Global and Planetary Change 31, 179-199.

Mangerud, J. 1981: The Early and Middle Weichselian in Norway: a review. Boreas 10, 381-393.

Mangerud, J. 2004: Ice sheet limits on Norway and the Norwegian continental shelf. In Ehlers, J. \& Gibbard, P. (eds.): Quaternary Glaciations - Extent and Chronology Part I: Europe, 271-294. Elsevier, Amsterdam.

Mangerud, J., Astakhov, V. I., Jakobsson, M. \& Svendsen, J. I. 2001a: Huge ice-age lakes in Russia. Journal of Quaternary Science 16, $773-777$.

Mangerud, J., Astakhov, V. I., Murray, A. \& Svendsen, J. I. 2001b: The chronology of a large ice-dammed lake and the Barents-Kara Ice Sheet advance, Northern Russia. Global and Planetary Change 31, 319-334.

Mangerud, J., Dokken, T., Hebbeln, D., Ingólfsson, Ó., Landvik, J. Y., Mejdahl, V., Svendsen, J. I. \& Vorren, T. O. 1998: Fluctuations of the Svalbard-Barents Sea Ice Sheet during the Last 150,000 Years. Quaternary Science Reviews 17, 11-42.

Mangerud, J., Jakobsson, M., Alexanderson, H., Asthakov, V., Clarke, G. K. C., Henriksen, M., Hjort, C., Krinner, G., Lunkka, P. J., Müller, P., Murray, A., Nikolskaya, O., Saarnisto, M. \& Svendsen, J. I. 2004: Ice-dammed lakes and rerouting of the drainage of northern Eurasia during the last glaciation. Quaternary Science Reviews 23, 1313-1332.

Mangerud, J., Sønstegaard, E., Sejrup, H. P. \& Haldorsen, S. 1981: A continuous Eemian-Early Weichselian sequence containing pollen and marine fossils at Fjøsanger, western Norway. Boreas 10, 137208.

Mangerud, J. \& Svendsen, J. I. 1992: The last interglacial-glacial period of Spitzbergen, Svalbard. Quaternary Science Reviews 11, 633-664.

Mangerud, J., Svendsen, J. I. \& Astakov, V. I. 1999: Age and extent of the Barents and Kara ice sheets in Northern Russia. Boreas 28, $46-80$.
Marks, L. 2004: Pleistocene glacial limits in Poland. In Ehlers, J. \& Gibbard, P. (eds.): Quaternary Glaciations - Extent and Chronology Part I: Europe, 295-300. Elsevier, Amsterdam.

Maslenikova, O. \& Mangerud, J. 2001: Where was the outlet of the ice-dammed Lake Komi, northern European Russia. Global and Planetary Change 31, 335-343.

Menke, B. 1985: Eem-Interglazial und Treene-Warmzeit in Husum/ Nordfriesland. Geologisches Jahrbuch A86, 63-99.

Miller, G. H., Sejrup, H. P., Lehman, S. C. \& Forman, S. L. 1989: Glacial history and marine environmental change during the last interglacial-glacial cycle, western Spitsbergen, Svalbard. Boreas $18,273-296$.

Milne, G. A., Davis, J. L., Mitrovica, J. X., Scherneck, H. G., Johansson, J. M., Vermeer, M. \& Koivula, H. 2002: Space-geodetic constraints on glacial isostatic adjustment in Fennoscandia. Science 291, 2381-2385.

Mitrovica, J. X. 1996: Haskell [1935] revisited. Journal of Geophysical Research 101, 555-569.

Mojski, J. E. 1992: Vistulian stratigraphy and TL dates in Poland. Sveriges Geologiska Undersökning Ca 81, 195-200.

Möller, P., Bolshiyanov, D. Y. \& Bergsten, H. 1999: Weichselian geology and paleoenvironmental history of the central Taymyr Peninsula, Siberia, indicating no glaciation during the last global glacial maximum. Boreas 28, 92-114.

Möller, P., Lubinski, D., Ingólfsson, Ó., Forman, S. L., Seidenkrantz, M.-S., Bolshiyanov, D. Yu., Lokrantz, H., Antonov, O., Pavlov, M., Ljung, K., Zeeberg, J. J. \& Andreev, A. 2006: Severnaya Zemlya, Arctic Russia: a nucleation area for Kara Sea ice sheets during the Middle to Late Quaternary. Quaternary Science Reviews (in press).

Molodkov, A. \& Yevzerov, V. 2004: ESR/OSL ages of long-debated subtill fossil-bearing marine deposits from the southern Kola peninsula: stratigraphic implications. Boreas 33, 123-131.

Müller, H. 1974: Pollenanalytische Untersuchungen und Jahresschichtenzhålungen an der holstein-zeitlichen Kieselgur von Munster-Breloh. Geologisches Jahrbuch A21, 107-140.

Nakada, M. \& Lambeck, K. 1987: Glacial rebound and relative sealevel variations: a new appraisal. Geophysical Journal Royal Astronomical Society 90, 171-224.

Nenonen, K. 1995: Pleistocene stratigraphy of southern Finland. In Ehlers, J., Kozarski, S. \& Gibbard, P. (eds.): Glacial Deposits in North-East Europe, 11-29. A. A. Balkema, Rotterdam.

Olsen, L. 1988: Stadials and interstadials during the Weichsel glaciation in Finnmarksvidda, northern Norway. Boreas 17, $517-$ 539.

Olsen, L. 1997: Rapid shifts in glacial extension characterise a new conceptual model for glacial variations during the Mid and Late Weichselian in Norway. Norges Geologiske Undersøkelse Bulletin $433,54-55$.

Olsen, L., Mejdahl, V. \& Selvik, S. F. 1996: Middle and late Pleistocene stratigraphy, chronology and glacial history in Finnmark, north Norway. Norges Geologisk Undersogelse Bulletin 429, $1-119$.

Olsen, L., Sveian, H. \& Bergstrøm, B. 2001: Rapid adjustments of the western part of the Scandinavian Ice Sheet during the Mid and Late Weichselian - a new model. Norwegian Journal of Geology 81 , 93-118.

Paterson, W. S. B. 1994: The Physics of Glaciers. 480 pp. Pergamon, New York

Potter, E. K., Esat, T. M., Schellmann, G., Radtke, U., Lambeck, K. \& McCulloch, M. T. 2004: Suborbital-period sea-level oscillations during marine isotope substage 5a and 5c. Earth and Planetary Science Letters 225, 191-204.

Potter, E. K. \& Lambeck, K. 2004: Reconciliation of sea-level observations in the Western North Atlantic during the last glacial cycle. Earth and Planetary Science Letters 217, 171-181.

Robertsson, A. \& Garcia Ambrosiana, K. 1988: Late Pleistocene stratigraphy at Boliden, northern Sweden. Boreas 17, 1-14. 
Robertsson, A. \& Rodhe, L. 1988: A Late Pleistocene sequence at Seitevare, Swedish Lapland. Boreas 17, 501-509.

Robertsson, A. M. \& Svedlund, J. O. 1997: Pleistocene stratigraphy in the Dellen region, central Sweden. Boreas 26, 237-260.

Saarnisto, M. \& Salonen, V. P. 1995: Glacial history of Finland. In Ehlers, J., Kozarski, S. \& Gibbard, P. (eds.): Glacial Deposits in North-East Europe, 3-10. A. A. Balkema, Rotterdam.

Salvigsen, O. 1981: Radiocarbon dated raised beaches in Kong Karls Land, Svalbard, and their consequences for the glacial history of the Barents Sea area. Geografiska Annaler 63A, 283-291.

Sejrup, H. P., Larsen, E., Landvik, J., King, E. L., Haflidason, H. \& Nesje, A. 2000: Quaternary glaciations in southern Fennoscandia: evidence from south-western Norway and the northern North Sea region. Quaternary Science Reviews 19, 667-685.

Spielhagen, R., Baumann, K. H., Erlenkeuser, H., Nowaczyk, N. R., Nørregaard-Pedersen, N., Vogt, C. \& Weiel, D. 2004: Arctic ocean deep-sea record of northern Eurasian ice sheet history. Quaternary Science Reviews 23, 1455-1483.

Stirling, C. H., Esat, T. M., Lambeck, K. \& McCulloch, M. T. 1998: Timing and duration of the Last Interglacial: evidence for a restricted interval of widespread coral reef growth. Earth and Planetary Science Letters 160, 745-762.

Sukhorukova, P. P. 1999: Late Pleistocene paleogeography of northwest Siberia. Journal of Geological Science 23, 37-42.

Svendsen, J. I. \& Alexanderson, H. 2004: Late Quaternary ice sheet history of northern Eurasia. Quaternary Science Reviews 23, 12291271.

Thiede, J. \& Astakhov, V. (eds.) 2004: What was QUEEN? Its history and international framework - an introduction to its final synthesis issue. Quaternary Science Reviews 23, 1225-1227.
Thiede, J. \& Bauch, H. A. (eds.) 1999: The Late Quaternary history of northern Eurasia and the adjacent Arctic Ocean: an introduction to QUEEN. Boreas 28, 3-242.

Thiede, J. \& Bauch, H. A. 2001: The late Quaternary stratigraphy and environments of northern Eurasia and the adjacent Arctic seas new contributions from QUEEN. Boreas 31, 7-10.

Troitsky, L. \& Punning, J. M. 1979: Pleistocene glaciation chronology of Spitsbergen. Boreas 8, 401-407.

Ukkonen, P., Lunkka, J. P., Jungner, H. \& Donner, J. 1999: New radiocarbon dates from Finnish mammoths indicating large icefree areas in Fennoscandia during the Middle Weichselian. Journal of Quaternary Science 14, 711-714.

Vorren, T. O., Vorren, K.-D., Alm, T., Gulliksen, S. \& Løvlie, R. 1988: The last deglaciation (20,000 to 11,000 B.P.) on Andøya, northern Norway. Boreas 17, 41-77.

Waelbroeck, C. \& Labeyrie, L. 2002: Sea-level and deep water temperature changes derived from benthic formainifera isotopic records. Quaternary Science Reviews 21, 295-305.

Zagwijn, W. H. 1983: Sea-level changes in the Netherlands during the Eemian. Geologie en Mijnbouw 63, 437-450.

Zagwijn, W. H. 1996: An analysis of Eemian climate in Western and Central Europe. Quaternary Science Reviews 15, 451-469.

Zale, R. \& Brydsten, L. 1993: The pre-Holocene marine limit on Hopen, Svalbard. Boreas 22, 159-164.

Znamenskaia, O. M. \& Cherminisova, Y. A. 1962: Problems of Stratigraphy of the Quaternary in the North-West European USSR. In Lavrova, M. A., Fadeyeva, A. P. \& ZhingarevDobroselsky, A. T. (eds.): Problems of stratigraphy of the Quaternary in the north-west European USSR, 125-139. Academy of Sciences, Moscow. 